US Army Corps

of Engineers .

\title{
Route-Specific Passage and Survival of Steelhead Kelts at The Dalles and Bonneville Dams, 2012
}

FINAL REPORT

B Rayamajhi J Kim

GR Ploskey AH Colotelo

CM Woodley Z Deng

MA Weiland T Fu

DM Faber

July 2013

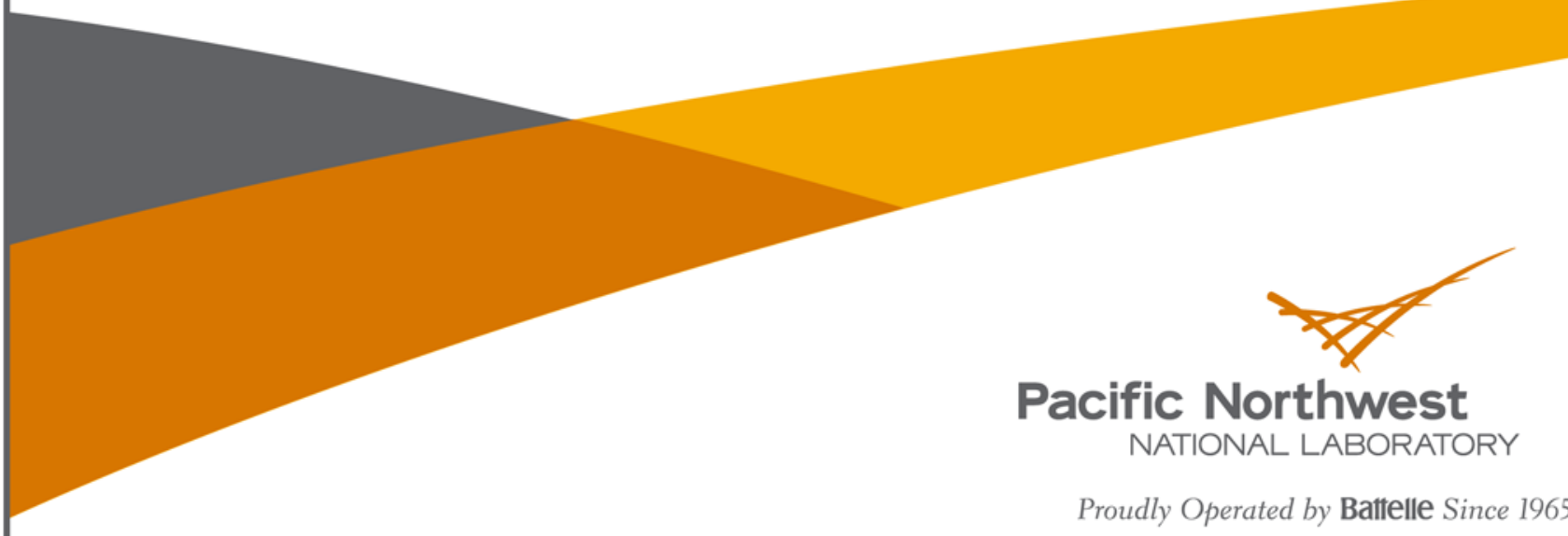




\title{
DISCLAIMER
}

This report was prepared as an account of work sponsored by an agency of the United States Government. Neither the United States Government nor any agency thereof, nor Battelle Memorial Institute, nor any of their employees, makes any warranty, express or implied, or assumes any legal liability or responsibility for the accuracy, completeness, or usefulness of any information, apparatus, product, or process disclosed, or represents that its use would not infringe privately owned rights. Reference herein to any specific commercial product, process, or service by trade name, trademark, manufacturer, or otherwise does not necessarily constitute or imply its endorsement, recommendation, or favoring by the United States Government or any agency thereof, or Battelle Memorial Institute. The views and opinions of authors expressed herein do not necessarily state or reflect those of the United States Government or any agency thereof.

\author{
PACIFIC NORTHWEST NATIONAL LABORATORY \\ operated by \\ BATTELLE \\ for the \\ UNITED STATES DEPARTMENT OF ENERGY \\ under Contract DE-AC05-76RL01830
}

Printed in the United States of America
Available to DOE and DOE contractors from the Office of Scientific and Technical Information,
P.O. Box 62, Oak Ridge, TN 37831-0062;
ph: (865) 576-8401
fax: $(865)$ 576-5728
email: reports@adonis.osti.gov
Available to the public from the National Technical Information Service
5301 Shawnee Rd., Alexandria, VA 22312
ph: (800) 553-NTIS (6847)
email: orders@ntis.gov <http://www.ntis.gov/about/form.aspx>
Online ordering: http://www.ntis.gov

This document was printed on recycled paper. 


\section{Route-Specific Passage and Survival of Steelhead Kelts at The Dalles and Bonneville Dams, 2012}

\section{FINAL REPORT}

$\begin{array}{ll}\text { B Rayamajhi } & \text { J Kim } \\ \text { GR Ploskey } & \text { AH Colotelo } \\ \text { CM Woodley } & \text { Z Deng } \\ \text { MA Weiland } & \text { T Fu } \\ \text { DM Faber } & \end{array}$

July 2013

Prepared for

U.S. Army Corps of Engineers, Portland District under an Interagency Agreement with the U.S. Department of Energy Contract DE-AC05-76RL01830

Pacific Northwest National Laboratory

Richland, Washington 99352 



\section{Preface}

The study reported herein was conducted by the Pacific Northwest National Laboratory (PNNL) for the U.S. Army Corps of Engineers, Portland District (CENWP). The PNNL project manager was Mr. Gene Ploskey. The CENWP technical lead was Mr. Robert Wertheimer. Under a subcontract with Pacific Northwest National Laboratory, the Pacific States Marine Fisheries Commission helped conduct the study. A team from the Oregon Department of Fish and Wildlife contributed by tagging lower Columbia River kelts, and a team from PNNL tagged and released Snake River kelts that were subsequently detected by arrays deployed for this study. The study was designed to estimate routespecific passage and survival for steelhead kelts passing through The Dalles and Bonneville dams and assist managers in determining powerhouse priority for operations at Bonneville Dam.

Suggested citation for this report:

Rayamajhi B, GR Ploskey, CM Woodley, MA Weiland, DM Faber, J Kim, AH Colotelo, Z Deng, and T Fu. 2013. Route-Specific Passage and Survival of Steelhead Kelts at The Dalles and Bonneville Dams, 2012. PNNL-22461, Pacific Northwest National Laboratory, Richland, Washington. 



\section{Executive Summary}

The purpose of this study was to estimate route-specific passage and survival for steelhead kelts passing through The Dalles Dam (TDA) and Bonneville Dam (BON) in spring 2012, and to help managers assign powerhouse priority for operations at BON. Lower Columbia River (LCR) kelts were collected and tagged with external micro-acoustic transmitters and passive integrated transponder (PIT) tags at three tributaries of the LCR and at one fish hatchery. Tributary flooding in 2012 prevented an Oregon Department of Fish and Wildlife team from collecting enough LCR kelts to meet study objectives, so kelts tagged for a Snake River (SR) kelt study (Colotelo et al. 2013) were used to bolster samples of tagged kelts passing through the two dams. Route-specific passage proportions were used to calculate passage efficiency and effectiveness metrics for the dams, spillways, and surface flow outlets (i.e., sluiceways at TDA and BON Powerhouse 1 [B1] and the BON Powerhouse 2 [B2] Corner Collector $[\mathrm{B} 2 \mathrm{CC}])$.

The study results for all kelts passing through TDA are summarized in Table ES.1, and results for kelts passing through BON are presented in Table ES.2.

Table ES.1. Statistical estimates of dam passage metrics, standard errors (SEs), and virtual-release sample sizes (N) for kelts passing through The Dalles Dam in spring 2012.

\begin{tabular}{|c|c|c|c|c|c|c|c|c|c|}
\hline \multirow[b]{2}{*}{ Performance Metrics } & \multicolumn{3}{|c|}{ All Kelts } & \multicolumn{3}{|c|}{ Snake River Kelts } & \multicolumn{3}{|c|}{$\begin{array}{l}\text { Lower Columbia River } \\
\text { Kelts }\end{array}$} \\
\hline & Estimate & SE & $\mathrm{N}$ & Estimate & SE & $\mathrm{N}$ & Estimate & SE & $\mathrm{N}$ \\
\hline Fish Passage Efficiency & 0.910 & 0.0216 & 177 & 0.914 & 0.0219 & 163 & 0.857 & 0.0935 & 14 \\
\hline Spill Passage Efficiency $\|$ dam & 0.842 & 0.0274 & 177 & 0.853 & 0.0278 & 163 & 0.714 & 0.1207 & 14 \\
\hline Sluiceway Passage Efficiency $\|$ dam & 0.068 & 0.0189 & 177 & 0.061 & 0.0188 & 163 & 0.143 & 0.0935 & 14 \\
\hline Sluiceway Passage Efficiency $\| \mathrm{PH}$ & 0.429 & 0.0935 & 28 & 0.417 & 0.1006 & 24 & 0.500 & 0.2500 & 4 \\
\hline Spill Passage Effectiveness \| dam & 2.092 & 0.0671 & 177 & 2.119 & 0.0696 & 163 & 1.774 & 0.3006 & 14 \\
\hline Sluiceway Passage Effectiveness \| dam & 5.10 & 1.4227 & 177 & 4.62 & 1.4152 & 163 & 10.76 & 7.0413 & 14 \\
\hline Sluiceway Passage Effectiveness \| PH & 19.28 & 4.2072 & 28 & 18.744 & 4.5272 & 24 & 22.493 & 11.2466 & 4 \\
\hline Forebay Residence Time & \multicolumn{9}{|c|}{ No forebay array was deployed so estimates are not available. } \\
\hline Tailrace Egress Time & \multicolumn{9}{|c|}{ No tailrace array was deployed so estimates are not available. } \\
\hline Dam passage survival & 0.8829 & 0.0252 & 177 & 0.8956 & 0.0249 & 163 & 0.7500 & 0.1336 & 14 \\
\hline Spillway passage survival & 0.9132 & 0.0243 & 149 & 0.9394 & 0.0296 & 139 & 0.7000 & 0.1449 & 10 \\
\hline Powerhouse passage survival & 0.7185 & 0.0860 & 28 & 0.6942 & 0.1021 & 24 & 0.7500 & 0.2165 & 4 \\
\hline Sluiceway passage survival & 0.9308 & 0.0753 & 12 & 0.9333 & 0.1233 & 10 & & & 2 \\
\hline Turbine passage survival & 0.5333 & 0.1288 & 16 & 0.5385 & 0.1383 & 14 & & & 2 \\
\hline
\end{tabular}


Table ES.2. Statistical estimates of dam passage metrics, standard errors (SEs) and virtual-release sample sizes (N) for kelts passing through Bonneville Dam in spring 2012.

\begin{tabular}{|c|c|c|c|c|c|c|c|c|c|}
\hline \multirow[b]{2}{*}{ Performance Metrics } & \multicolumn{3}{|c|}{ All Kelts } & \multicolumn{3}{|c|}{ Snake River Kelts } & \multicolumn{3}{|c|}{$\begin{array}{l}\text { Lower Columbia River } \\
\text { Kelts }\end{array}$} \\
\hline & Estimate & SE & $\mathrm{N}$ & Estimate & SE & $\mathrm{N}$ & Estimate & SE & $\mathrm{N}$ \\
\hline Fish Passage Efficiency & 0.8400 & 0.0290 & 163 & 0.8700 & 0.0290 & 138 & 0.6800 & 0.0930 & 25 \\
\hline Spill Passage Efficiency $\|$ dam & 0.5090 & 0.0390 & 163 & 0.5360 & 0.0420 & 138 & 0.3600 & 0.0960 & 25 \\
\hline B1 Sluiceway Passage Efficiency $\|$ dam & 0.1230 & 0.0260 & 163 & 0.1230 & 0.0280 & 138 & 0.1200 & 0.0650 & 25 \\
\hline B2CC Passage Efficiency $\|$ dam & 0.1780 & 0.0300 & 163 & 0.1880 & 0.0330 & 138 & 0.1200 & 0.0650 & 25 \\
\hline SFO Passage Efficiency $\|$ dam & 0.3010 & 0.0360 & 163 & 0.3120 & 0.0390 & 138 & 0.2400 & 0.0850 & 25 \\
\hline Spill Passage Effectiveness $\|$ dam & 1.268 & 0.0975 & 163 & 1.335 & 0.1057 & 138 & 0.896 & 0.2390 & 25 \\
\hline B1 Sluiceway Passage Effectiveness \| dam & 41.510 & 8.6936 & 163 & 41.670 & 9.4644 & 138 & 40.600 & 21.9866 & 25 \\
\hline B2CC Passage Effectiveness $\|$ dam & 12.640 & 2.1281 & 163 & 13.385 & 2.3648 & 138 & 8.525 & 4.6173 & 25 \\
\hline SFO Passage Effectiveness $\|$ dam & 17.650 & 2.1086 & 163 & 18.295 & 2.3148 & 138 & 14.091 & 5.0151 & 25 \\
\hline B2 JBS Passage Efficiency $\|$ dam & 0.0310 & 0.0140 & 163 & 0.0220 & 0.0120 & 138 & 0.0800 & 0.0540 & 25 \\
\hline B1 FPE (i.e., B1 SLE || B1) & 0.4880 & 0.0781 & 41 & 0.5150 & 0.0870 & 33 & 0.3750 & 0.1712 & 8 \\
\hline B1 Sluiceway Passage Effectiveness \| B1 & 47.571 & 7.6128 & 41 & 50.238 & 8.4842 & 33 & 36.570 & 16.6920 & 8 \\
\hline B2 FPE (i.e., B2CC + B2 JBS) $\|$ B2) & 0.8718 & 0.0535 & 39 & 0.9355 & 0.0441 & 31 & 0.6250 & 0.1712 & 8 \\
\hline B2CC Passage Efficiency \| B2 & 0.7440 & 0.0700 & 39 & 0.8390 & 0.0660 & 31 & 0.3750 & 0.1710 & 8 \\
\hline B2 JBS Passage Efficiency $\|$ B2 & 0.1282 & 0.0535 & 39 & 0.0968 & 0.0531 & 31 & 0.2500 & 0.1531 & 8 \\
\hline B2CC Passage Effectiveness $\|$ B2 & 16.379 & 1.5401 & 39 & 18.474 & 1.4551 & 31 & 8.260 & 3.7702 & 8 \\
\hline BON Forebay Residence Time (median h) & 0.585 & 2.786 & 138 & 0.5431 & 2.353 & 113 & 0.790 & 11.157 & 25 \\
\hline B1 Forebay Residence Time (median h) & 2.843 & 7.027 & 37 & 2.843 & 2.803 & 27 & 3.041 & 2.814 & 8 \\
\hline B2 Forebay Residence Time (median h) & 0.271 & 3.151 & 33 & 0.461 & 0.216 & 14 & 1.985 & 34.745 & 8 \\
\hline BON Tailrace Egress Time (median h) & 0.375 & 2.138 & 93 & 0.374 & 2.686 & 74 & 0.375 & 0.448 & 19 \\
\hline B1 Tailrace Egress Time (median h) & 0.370 & 5.673 & 35 & 0.393 & 7.353 & 27 & 0.289 & 0.861 & 8 \\
\hline B2 Tailrace Egress Time (median h) & 0.293 & 0.088 & 10 & 0.281 & 0.097 & 8 & 0.412 & 0.149 & 3 \\
\hline Dam Passage Survival & 0.8666 & 0.0270 & 163 & 0.8999 & 0.0270 & 138 & 0.6800 & 0.0933 & 25 \\
\hline Spillway Passage Survival & 0.9106 & 0.0329 & 83 & 0.9256 & 0.0322 & 74 & 0.7778 & 0.1386 & 9 \\
\hline Surface flow outlet passage survival & 0.8869 & 0.0478 & 49 & 0.8702 & 0.0539 & 43 & 1.0000 & 0.0000 & 6 \\
\hline B1 Passage Survival & 0.7859 & 0.0653 & 41 & 0.7934 & 0.0719 & 33 & 0.7500 & 0.1531 & 8 \\
\hline B2 Passage Survival & 0.8626 & 0.0601 & 39 & 0.9531 & 0.0470 & 31 & 0.5000 & 0.1768 & 8 \\
\hline B1 Sluiceway Passage Survival & 0.8036 & 0.0900 & 20 & 0.7647 & 0.1029 & 17 & & & 3 \\
\hline B2CC Passage Survival & 0.9458 & 0.0493 & 29 & 0.9423 & 0.0557 & 26 & & & 3 \\
\hline B1 Turbine Passage Survival & 0.7692 & 0.0943 & 21 & 0.8250 & 0.1003 & 16 & 0.6000 & & 5 \\
\hline B2 Turbine Passage Survival & 0.6000 & & 5 & & & 2 & & & 3 \\
\hline BON Turbine Passage Survival & 0.7385 & 0.0884 & 26 & 0.8426 & 0.0895 & 18 & 0.5000 & 0.1768 & 8 \\
\hline B2 JBS Passage Survival & 0.6000 & & 5 & & & 3 & & & 2 \\
\hline
\end{tabular}


While limited sample sizes resulted in high standard errors and few 95\% confidence intervals that did not overlap, differences in point estimates suggest that B2 should be the priority powerhouse for kelt passage, at least until more precise estimates demonstrate otherwise. This conclusion is based on the following observations from results listed in Table ES.2. First, estimates of B2 fish passage efficiency (FPE) were higher than estimates for B1 FPE for all kelts (38.4\%), SR kelts (42.1\%), and LCR kelts (25.0\%). Second, estimates of B2CC passage efficiency relative to B2 were higher than estimates of B1 sluiceway efficiency for all kelts $(25.6 \%)$ and SR kelts $(32.4 \%)$ although not for LCR kelts. Third, the point estimate of B2 passage survival was $7.67 \%$ higher than the estimate for B1 passage survival for all kelts, and for SR kelts it was $15.97 \%$ higher for B2 than it was for B1. Fourth, mean and median point estimates of forebay residence times usually were longer for kelts passing through B1 than they were for kelts passing through B2. For example, mean and median differences (B1 minus B2 forebay residence time) were $10.89 \mathrm{~h}$ and $2.57 \mathrm{~h}$ for all kelt and $7.38 \mathrm{~h}$ and $2.38 \mathrm{~h}$ for SR kelt. The difference in medians was $1.06 \mathrm{~h}$ for LCR kelts. While none of these differences was significant given the sample sizes in this study, point estimate comparisions strongly suggest that B2 should be the priority powerhouse. High flow in 2012 provided a good test bed for comparing metrics for the two powerhouses because both were operated at available capacity. 



\section{Acknowledgments}

This study was the result of hard work by biologists at PNNL, the Oregon Department of Fish and Wildlife (ODFW), and the Pacific States Marine Fisheries Commission (PSMFC).

- PNNL: E Fischer, C Vernon, B Lamarche, E Choi, A Flory, J Hughes, S Zimmerman, M Greiner, B Jones, R Harnish, G McMichael, K Ham, G Squeochs, R Brown, X Li, and J Duncan

- ODFW: J Schmitz, M Lubejko, A Bianco, W Wilson, S Smith, B Poxon, J Gidley, and J Stahler

- PSMFC: R Martinson, G Batten III, R Blanchard, R Davis, D Etherington, M Hennen, T Mitchell, $\mathrm{S}$ Carpenter, and D Trott

- USACE: R Wertheimer was the Contracting Officers Technial Representative (COTR) in the Portland District, and biologists at The Dalles Dam (P Keller, B Cordie) and Bonneville Dam (B Hausmann, J Rerecich, I Royer, and A Traylor) provided coordination with the respective projects to facilitate safe and timely installation and removal of equipment and safe in-season monitoring. 



\section{Acronyms and Abbreviations}

\begin{tabular}{|c|c|}
\hline${ }^{\circ} \mathrm{C}$ & degree(s) Celsius \\
\hline $3 \mathrm{D}$ & three-dimensional \\
\hline ATLAS & Active Tag Life Adjusted Survival \\
\hline B1 & Bonneville Powerhouse 1 \\
\hline B2 & Bonneville Powerhouse 2 \\
\hline $\mathrm{B} 2 \mathrm{CC}$ & Bonneville Powerhouse 2 Corner Collector \\
\hline $\mathrm{BON}$ & Bonneville Dam \\
\hline CENWP & U.S. Army Corps of Engineers, Portland District \\
\hline $\mathrm{CI}$ & confidence interval \\
\hline CJS & Cormack, Jolly, Seber \\
\hline CR & Columbia River \\
\hline $\mathrm{d}$ & $\operatorname{day}(\mathrm{s})$ \\
\hline DART & Data Access in Real Time \\
\hline FPE & fish passage efficiency \\
\hline $\mathrm{g}$ & $\operatorname{gram}(\mathrm{s})$ \\
\hline $\mathrm{h}$ & hour(s) \\
\hline JBS & juvenile bypass system \\
\hline JSATS & Juvenile Salmon Acoustic Telemetry System \\
\hline kcfs & thousand cubic feet per second \\
\hline $\mathrm{kHz}$ & kilohertz \\
\hline $\mathrm{km}$ & kilometer(s) \\
\hline $\mathrm{km}^{2}$ & square kilometer(s) \\
\hline LCR & Lower Columbia River \\
\hline LGR & Lower Granite Dam \\
\hline $\mathrm{m}$ & meter(s) \\
\hline MATLAB & MATrix LABoratory \\
\hline $\mathrm{mm}$ & millimeter(s) \\
\hline ODFW & Oregon Department of Fish and Wildlife \\
\hline PIT & passive integrated transponder \\
\hline PNNL & Pacific Northwest National Laboratory \\
\hline PSMFC & Pacific States Marine Fisheries Commission \\
\hline $\mathrm{rkm}$ & river kilometer(s) \\
\hline s & second(s) \\
\hline SAS & Statistical Analysis System \\
\hline SE & standard error \\
\hline$\widehat{\mathrm{SE}}$ & estimated standard error (from a sample) \\
\hline
\end{tabular}


SFO

SLE

SLE

SPE

SR

TDA

USACE surface flow outlet

sluiceway passage efficiency

Sluiceway Passage Efficiency Relative to an Adjacent Powerhouse spill passage efficiency

Snake River

The Dalles Dam

U.S. Army Corps of Engineers 


\section{Contents}

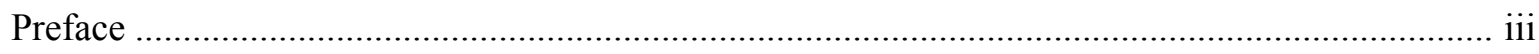

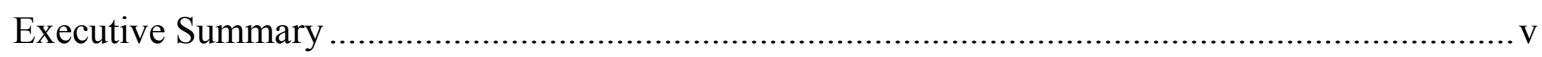

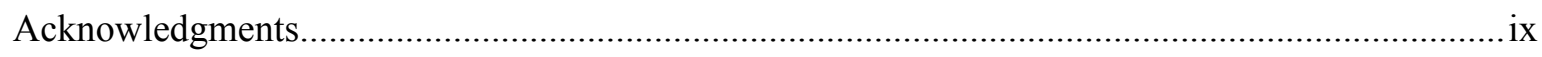

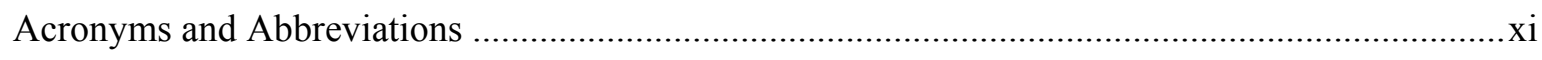

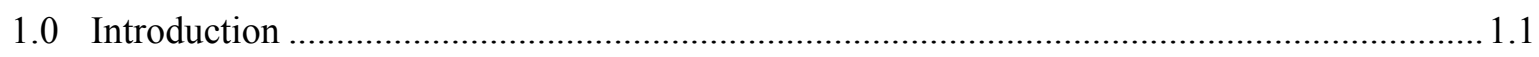

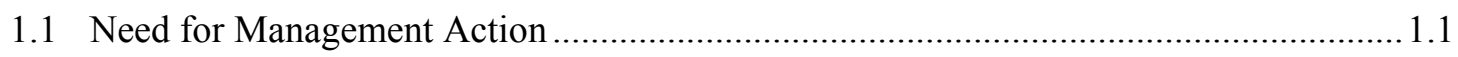

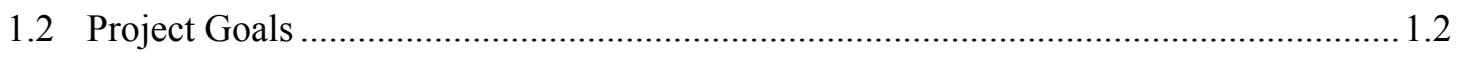

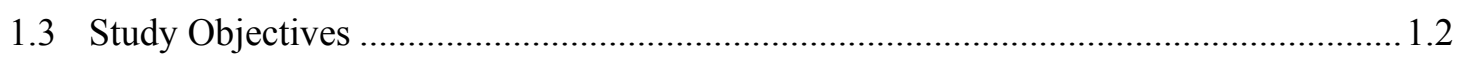

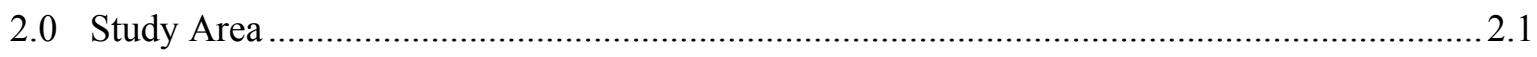

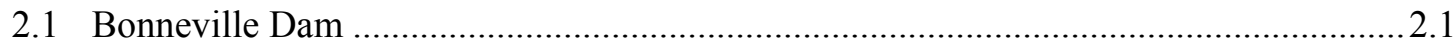

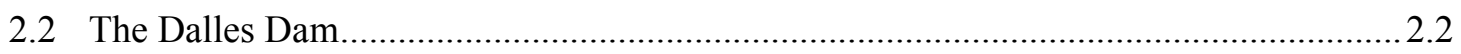

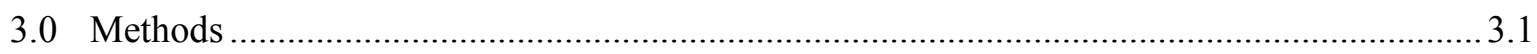

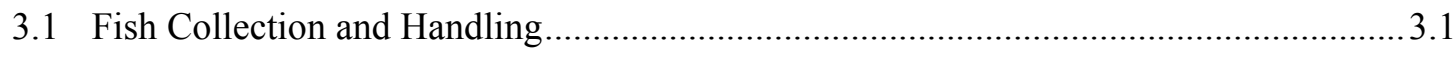

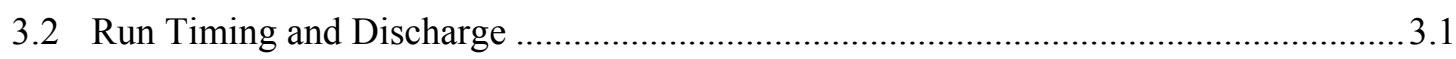

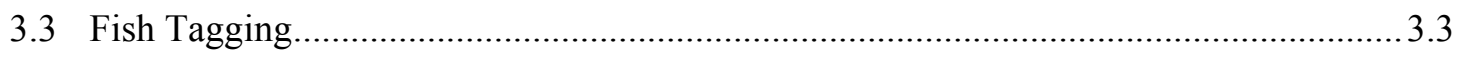

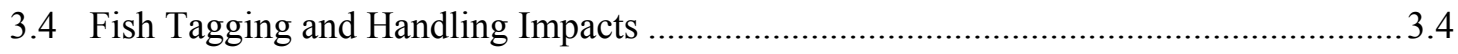

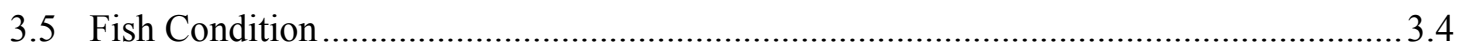

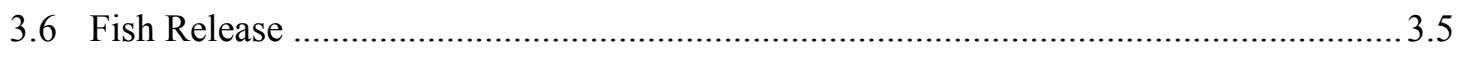

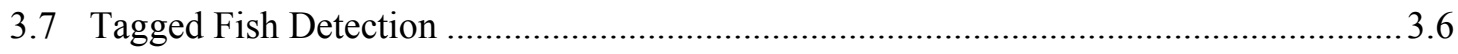

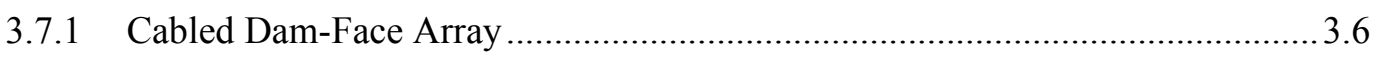

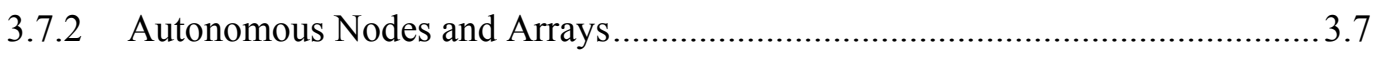

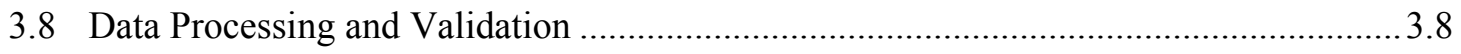

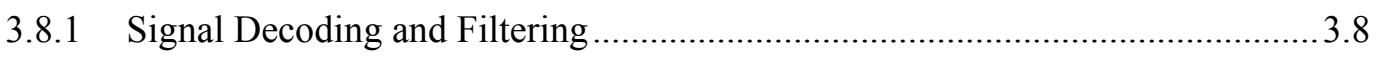

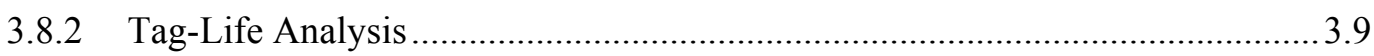

3.9 Supplementing Sample Sizes by Regrouping Snake River Kelts .................................. 3.9

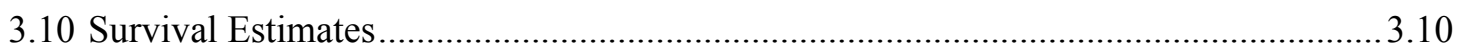

3.11 Estimating Dam Passage Time and Passage Metrics …................................................. 3.10

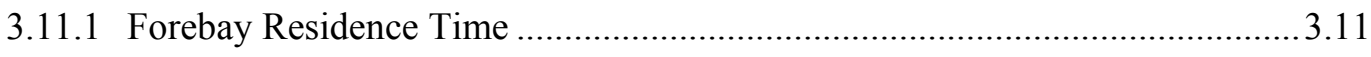

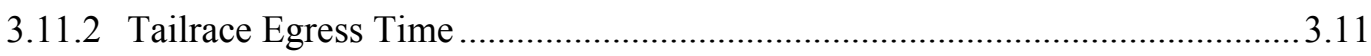

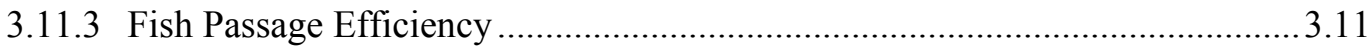

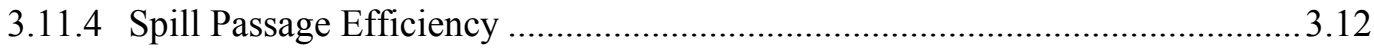

3.11.5 Sluiceway Passage Efficiency Relative to the Dam ............................................13

3.11.6 Sluiceway Passage Efficiency Relative to an Adjacent Powerhouse .................3.14

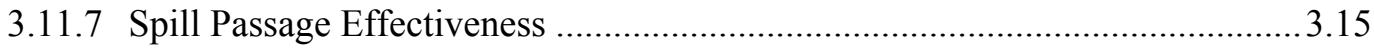

3.11.8 Sluiceway Passage Effectiveness ……….................................................... 3.16 


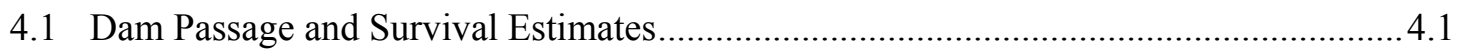

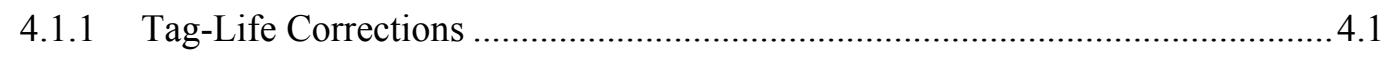

4.1.2 The Dalles Dam Passage and Survival Estimates.............................................. 4.1

4.1.3 Bonneville Dam Passage and Survival Estimates ............................................. 4.2

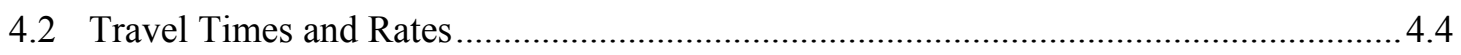

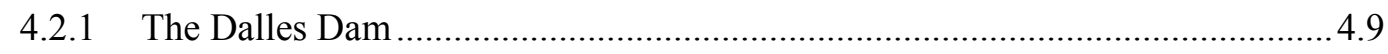

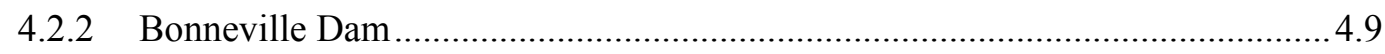

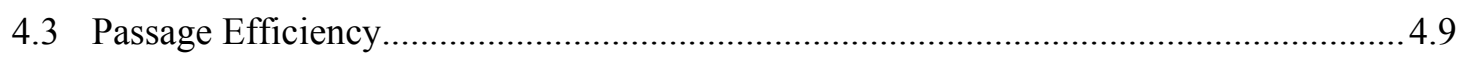

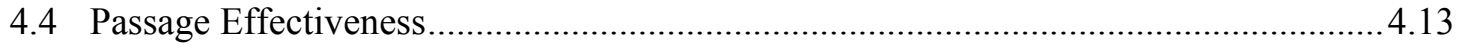

4.5 Iteroparity and Upstream Movement ................................................................... 4.15

4.6 Kelt Condition and Release ................................................................................. 4.16

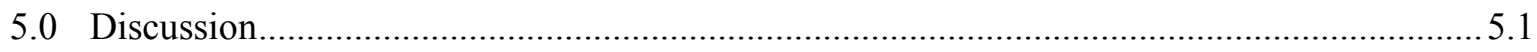

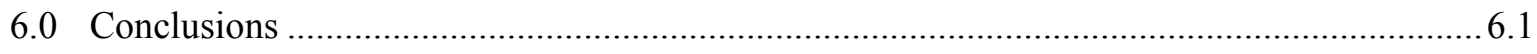

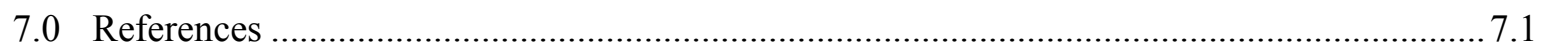




\section{Figures}

2.1 Location of Columbia River tributaries and sub-tributaries used for kelt tagging and collection

2.2 Aerial view of Bonneville Dam.

2.3 Aerial view of The Dalles Dam

3.1 Daily discharge and the 108-yr median daily statistic flow for March through June 2012, recorded by the U.S. Geological Survey gaging station in the Deschutes River at Moody, Oregon

3.2 Daily and 49-yr median daily statistic discharge for March through June 2012, recorded by the U.S. Geological Survey gaging station in the Hood River at Tucker Bridge, Oregon...

3.3 Cumulative proportion of downstream migrating kelts observed by date at the Deschutes River traps in 2012

3.4 Picture showing a PIT tag, acoustic tag, and a Floy T-bar tag with an acoustic tag.

3.5 Floy tag injection using a tagging gun and a Floy T-bar tag after attachment.

3.6 Flow chart showing JSATS array components.

3.7 Front view of a zigzag hydrophone deployment at three turbines to form two independent detection arrays

3.8 Autonomous node configuration with a hydrophone attached at the top of the node body, and a view of the node bottom where a removable battery compartment would be attached....

4.1 Survival estimates for all kelts through The Dalles Dam.

4.2 Survival estimates for kelts through Bonneville Dam

4.3 Passage efficiency estimates with 95\% CI for all kelts, SR kelts, and LCR kelts through The Dalles Dam.

4.4 Passage efficiency estimates by route with 95\% CI for all kelts, SR kelts, and LCR kelts through Bonneville Dam.

4.5 Passage effectiveness estimates with 95\% CI for all kelts, SR kelts, and LCR kelts through Bonneville Dam.

4.6 Passage effectiveness estimates with 95\% CI for kelts passing through Bonneville Dam.

5.1 Kelt passage percentage and survival estimates for TDA routes.....

5.2 Kelt passage percentage and survival estimates for BON routes. 


\section{Tables}

ES.1 Statistical estimates of dam passage metrics, standard errors, and virtual-release sample sizes for kelts passing throughThe Dalles Dam in spring 2012 .........................................

ES.2 Statistical estimates of dam passage metrics, standard errors, and virtual-release sample sizes for kelts passing through Bonneville Dam in spring 2012 ......................................... vi

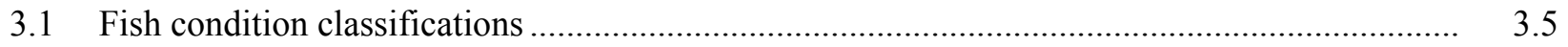

3.2 Number of kelts released by location and distance upstream from the mouth of the Columbia River.

4.1 Passage proportion and survival estimates with standard errors for all kelts, SR kelts, and LCR kelts through The Dalles Dam

4.2 Passage proportions and survival rates with standard errors for all kelts, SR kelts, and LCR kelts through Bonneville Dam ....

4.3 Passage percentages and survival rates with standard errors for all kelts, SR kelts, and LCR kelts passing through Bonneville Dam routes and subroutes.

4.4 Travel times for kelts passing through listed river reaches from release site to the most downstream array for the LCR in 2012 .

4.5 Rate of travel for kelts passing through listed river reaches from release site to the most downstream array for the LCR in 2012 .

4.6 Comparison of distribution statistics for forebay residence times of all, SR, and LCR kelts passing through B1 and B2 in 2012

4.7 Comparison of distribution statistics for forebay residence times of all, SR, and LCR kelts passing through B1 and B2 in 2012

4.8 Fish passage efficiency, spillway passage efficiency, and sluiceway passage efficiency for kelts passing through The Dalles Dam.

4.9 Passage efficiency estimates by route for kelts passing through Bonneville Dam.

4.10 Passage effectiveness estimates for kelts passing through The Dalles Dam.

4.11 Passage effectiveness estimates for kelts passing through Bonneville Dam 


\subsection{Introduction}

The study documented in this report was conducted in spring 2012 to estimate route-specific passage and survival for steelhead kelts passing through The Dalles Dam (TDA) and Bonneville Dam (BON) in the lower Columbia River, and to help fisheries managers assign powerhouse priority for operations at BON. Biologists at Pacific Northwest National Laboratory (PNNL), in collaboration with biologists from the Oregon Department of Fish and Wildlife and Pacific States Marine Fisheries Commission, conducted the study for the U.S. Army Corps of Engineers (USACE) Portland District (CENWP).

\subsection{Need for Management Action}

The Columbia River Basin extends over $640,000 \mathrm{~km}^{2}$, supporting a variety of ecotypes (McClure et al. 2003). It supports several anadromous salmon species during their periodic kelt migration to and from the Pacific Ocean. The construction of hydroelectric dams on the Columbia River and its tributaries have significantly altered the river habitat and slowed the upstream and downstream migration of the salmon species.

Steelhead (Oncorhynchus mykiss) is one of four species of anadromous salmonids within 12 evolutionarily significant units in the Columbia River basin listed under the Endangered Species Act (Waples 1991; Ford 2011). Steelhead were once very abundant in the Columbia River with peak wild run sizes ranging up to 500,000 adults (TAC 1997). Over the last century, the steelhead population sizes have been significantly reduced. Between 1938 and 1980, the adult summer steelhead counts (from April 1 through October 31) at BON fluctuated around 150,000 fish, but after 1985, due to the increased hatchery production, the total yearly steelhead counts were increased. The average steelhead run at BON from 1985 to 1995 totaled 255,900, of which 21\% were wild steelhead (TAC 1997). For the past 10 years (2002-2011), the steelhead run at BON averaged 389,000, and only about 30\% were wild steelhead (Columbia River Data Access in Real Time [DART] 2013). For research and management purposes, the steelhead run has been divided into two types: steelhead entering freshwater and passing through BON before August 25 are referred to as the $\underline{\mathrm{A}}$ run, whereas any run after August 25 is referred to as the $\underline{\mathrm{B}}$ run (Winans et al. 2004). Moreover, $\underline{A}$ run stocks are predominantly age- 1 ocean fish and $\underline{B}$ run stocks are age-2 ocean fish (Busby et al. 1996).

Steelhead are iteroparous in nature, i.e., capable of repeated spawning. Steelhead kelt return rates in a multi-year study conducted at John Day, McNary, and Lower Granite dams from 2000 through 2004 were $5.45 \%, 5.37 \%$, and $0.69 \%$, respectively (Boggs et al. 2004, 2008). About $2.6 \%$ of kelts bearing passive integrated transponder (PIT) tags migrated twice to spawn and $0.03 \%$ migrated three times. The fertility of repeat spawners tends to be higher than first time spawners and contributes to genetic diversity (Ducharme 1969; Niemelä et al. 2000). Post-spawned steelhead (kelts) have low energy reserves with resultant decreased swimming ability, and are highly susceptible to physiological stress when passing through hydroelectric dams and barrier structures, which can contribute to mortality (Booth et al. 1997; Scruton et al. 2007). Reduced water velocities in dam reservoirs and time spent in search of dam passage routes reduce kelt migration rates while increasing their vulnerability to predation (Wertheimer and Evans 2005; Wertheimer 2007). Management actions are needed to protect kelts and to ensure rapid safe passage routes through the hydropower system are available during outmigration to the ocean. 


\subsection{Project Goals}

The main goal of this project was to estimate route-specific passage for tagged kelts passing through TDA and BON in the lower Columbia River (LCR). Secondary goals included comparing the efficiency and effectiveness of passage through non-turbine routes such as surface flow outlets (SFOs) or spillways, and assessing the route-specific survival of kelts. Study results should help fisheries managers understand the relative efficiency and effectiveness of non-turbine routes and develop operations to facilitate dam passage for kelts to increase their survival rate. Moreover, the results will update the status on kelt dam passage and survival estimates since the study conducted by Wertheimer and Evans (2005).

\subsection{Study Objectives}

The primary objectives of the study were to estimate the following:

- route-specific passage proportions for kelts passing through TDA (spillway, turbine, and sluiceway) and BON (spillway, Bonneville Powerhouse 1 [B1] turbine, B1 sluiceway, Bonneville Powerhouse 2 [B2]-turbine, B2-Corner Collector [B2CC], and B2-juvenile bypass system [JBS]).

- fish passage efficiency (FPE), spill passage efficiency (SPE) and effectiveness, SFO passage efficiency and effectiveness for each dam, and the efficiency and effectiveness of the B1 sluiceway and $\mathrm{B} 2 \mathrm{CC}$ relative to $\mathrm{BON}$ or to their respective powerhouses.

- forebay residence time - the amount of time spent from first detection on the forebay array to the last detection at the dam-face array just before passing through the dam.

- tailrace egress time - the amount of time from last detection on the dam-face array to last detection on the tailrace array.

- virtual single-release dam passage survival rates for kelts passing through TDA and BON and routespecific rates when warranted by sample sizes.

In documenting how the study objectives were met, the ensuing sections of this report first describe the study area, then the study methods and results, followed by a discussion of findings and related conclusions. References for the sources cited in the report are listed in the final section. 


\subsection{Study Area}

The project study area included three LCR tributaries of the Columbia River where downstream migrating kelts were collected, tagged, and released and approximately $217 \mathrm{~km}$ of the main-stem LCR. The LCR portion was from the confluence of the Deschutes River, which joins the Columbia River about 20 river kilometers (rkm) upstream of TDA at Columbia River (CR) rkm 330 (CR330), downstream to Kalama, Washington (CR113). Kelts were collected and tagged in two Deschutes River tributaries (Bakeoven Creek and Buck Hollow Creek); Fifteenmile Creek, which meets the Columbia River just downstream of TDA; and in Hood River and its Neal Creek tributary, approximately $41 \mathrm{rkm}$ upstream of BON (Figure 2.1). In addition, wild hatchery brood stock from the Parkdale Fish Hatchery were tagged after they had spawned. These broodstocks were collected at the weir on the east fork of the Hood River.

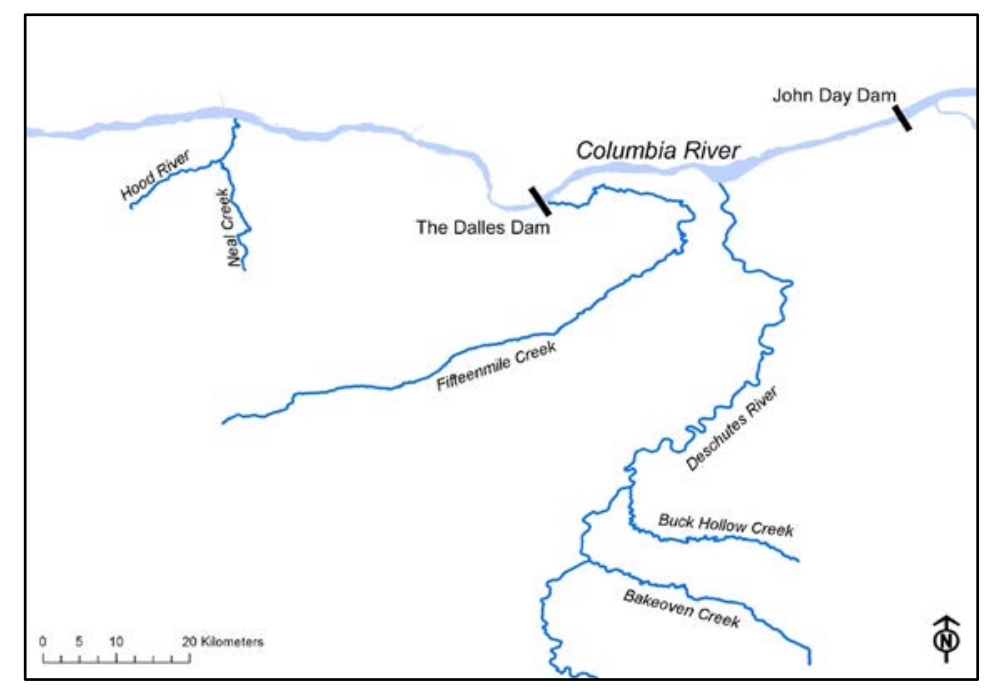

Figure 2.1. Location of Columbia River tributaries and sub-tributaries used for kelt tagging and collection.

\subsection{Bonneville Dam}

Located at CR234, BON is the most downstream dam in the Columbia River and is about $65 \mathrm{~km}$ upstream and east of Portland, Oregon. Dam structures consist of two powerhouses, a spillway, and a navigation lock. The first powerhouse (B1), with 10 turbine units and four forebay sluiceway outlets, is located between the Oregon shore and Bradford Island. The spillway, which has 18 spill bays, spans the north channel between Bradford Island and Cascades Island. The second powerhouse (B2), which has eight turbines and the B2CC, is located between Cascades Island and the Washington shore (Figure 2.2). 


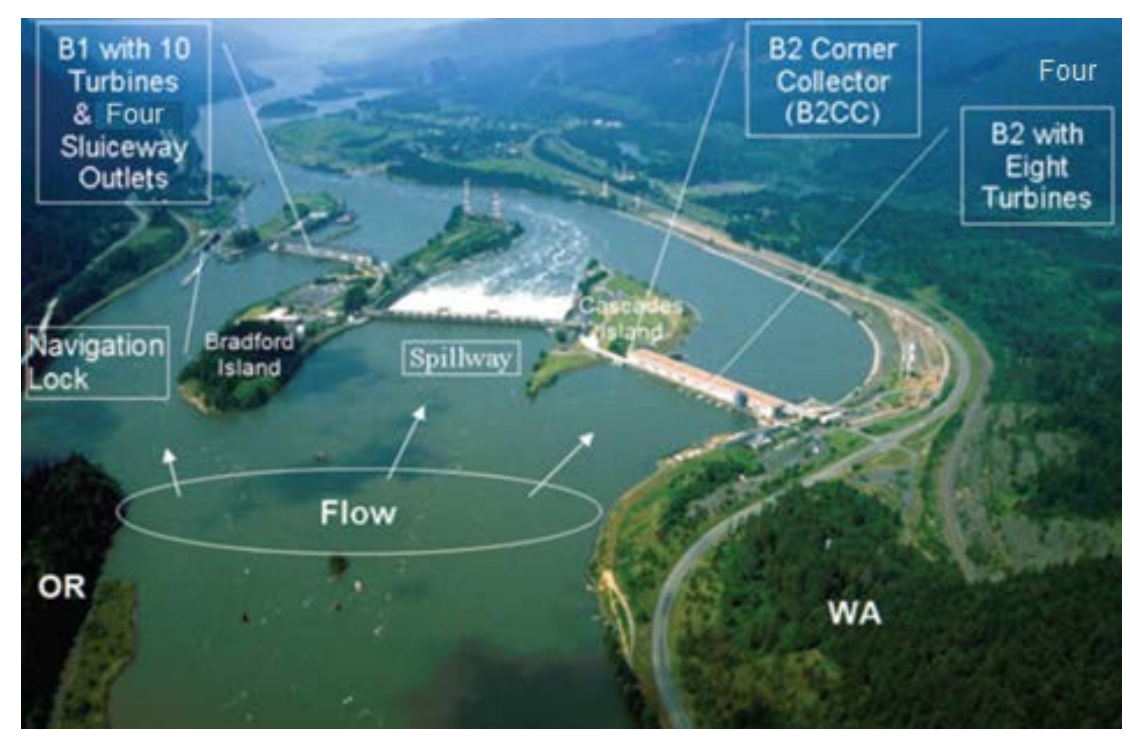

Figure 2.2. Aerial view of Bonneville Dam.

Passage routes through a powerhouse at BON could be through SFOs or turbines, or through a JBS at B2. Kelts entering the JBS are screened from a B2 turbine intake and diverted to a gatewell slot containing two orifices leading to a bypass channel that transports them to a downstream outfall. The JBS system in B1 was removed in 2004, because other routes were deemed safer for fish. The B2CC is a modified ice trash sluiceway channel at B2 that was lengthened in 2003, and it discharges water from the downstream tip of the Cascades Island.

\subsection{The Dalles Dam}

Located at CR309, TDA is the second hydropower dam upstream from the mouth of the Columbia River, approximately $75 \mathrm{~km}$ upstream from BON. It consists of a navigation lock, a spillway with 23 spill bays that runs perpendicular to the main river channel, and a powerhouse with 22 turbines that runs parallel to the main river channel (Figure 2.3). The major passage routes for downstream migrating kelts include the spillway (opened from early April through August), the ice/trash sluiceway (when opened), and turbines. Unlike other dams in the LCR, TDA lacks a JBS and PIT-tag detection facilities. A new 850-ft-long wall extending downstream into the tailrace between spill bays 8 and 9 was completed in 2010 to reduce tailrace egress times of juvenile salmonids passing in spill and to increase spill passage survival rates (Figure 2.3). When the majority of spill is through bays 1 through 8 , the wall prevents most spillway-passed fish from traveling south into a predator-infested maze of rock outcroppings on the Oregon side of the channel. 


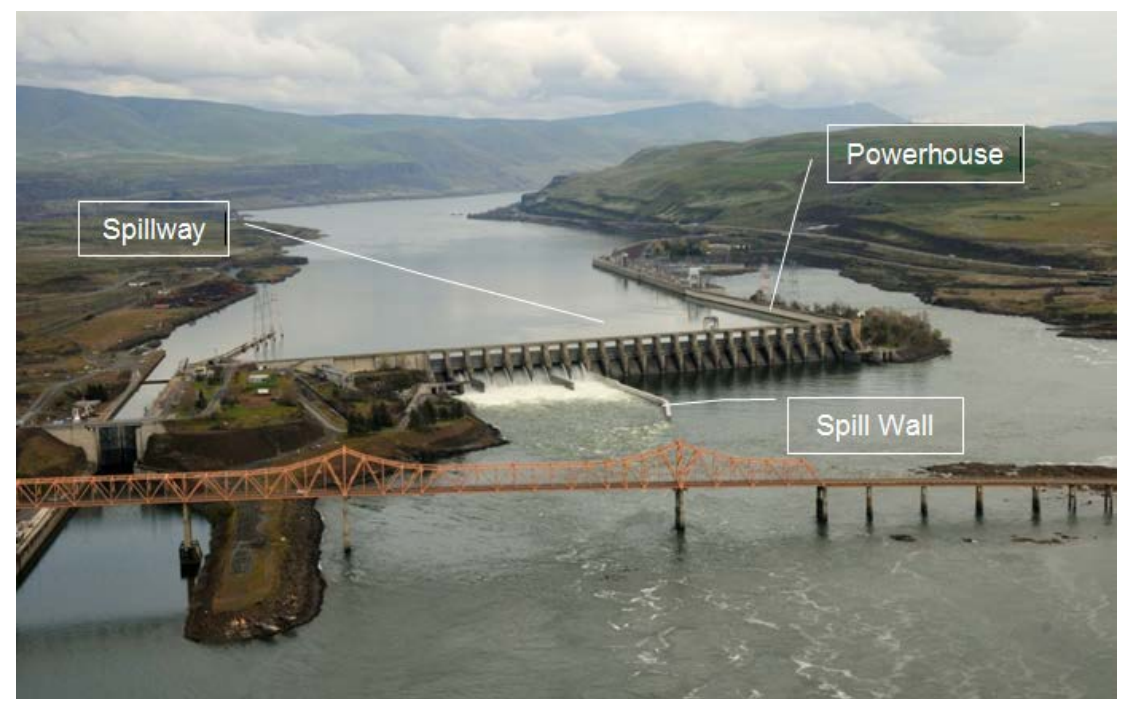

Figure 2.3. Aerial view of The Dalles Dam. 



\subsection{Methods}

Study methods include fish collection and handling, run timing and tributary discharge, fish tagging, tagging and handling impacts, fish condition, fish release, tagged fish detection systems, signal processing and filtering, survival estimates, and estimation of passage metrics.

\subsection{Fish Collection and Handling}

Kelts were selected for tagging based on their condition and availability at each collection location. An Oregon Department of Fish and Wildlife team collected and tagged 58 steelhead kelts from weir and box traps deployed in tributaries (40 fish) or from the Parkdale Hatchery at Hood River (18 fish). Seven fish were hatchery spawned and 51 were wild. Box traps are typically used for trapping juveniles but are also used for trapping adults. One kelt was caught in a box trap, while the others were caught in weir traps. The fork lengths of these fish ranged from $50 \mathrm{~cm}$ to $86 \mathrm{~cm}$; the average length was $67.5 \mathrm{~cm}$. The sex ratio of collected kelts was 29 females to 27 males; the sex of two was not determined. Numbers of kelt tagged and released at each site are described in Section 3.6 (Fish Release) below.

\subsection{Run Timing and Discharge}

The collection of kelts for tagging was heavily affected by the extremely high flows in the Deschutes River basin and Hood River in early spring 2012 (Figure 3.1 and Figure 3.2). Due to these high flows, trap installation was delayed and traps were not fully functional until April 12, 2012. The first kelts were tagged with Juvenile Salmon Acoustic Telemetry System (JSATS) acoustic micro-transmitters and PIT tags on April 12; by this date almost $90 \%$ of the kelts had already passed downstream (Figure 3.3). This drastically reduced the sample size from the proposed 400 kelts that we anticipated to tag for this study to 58 kelts. 


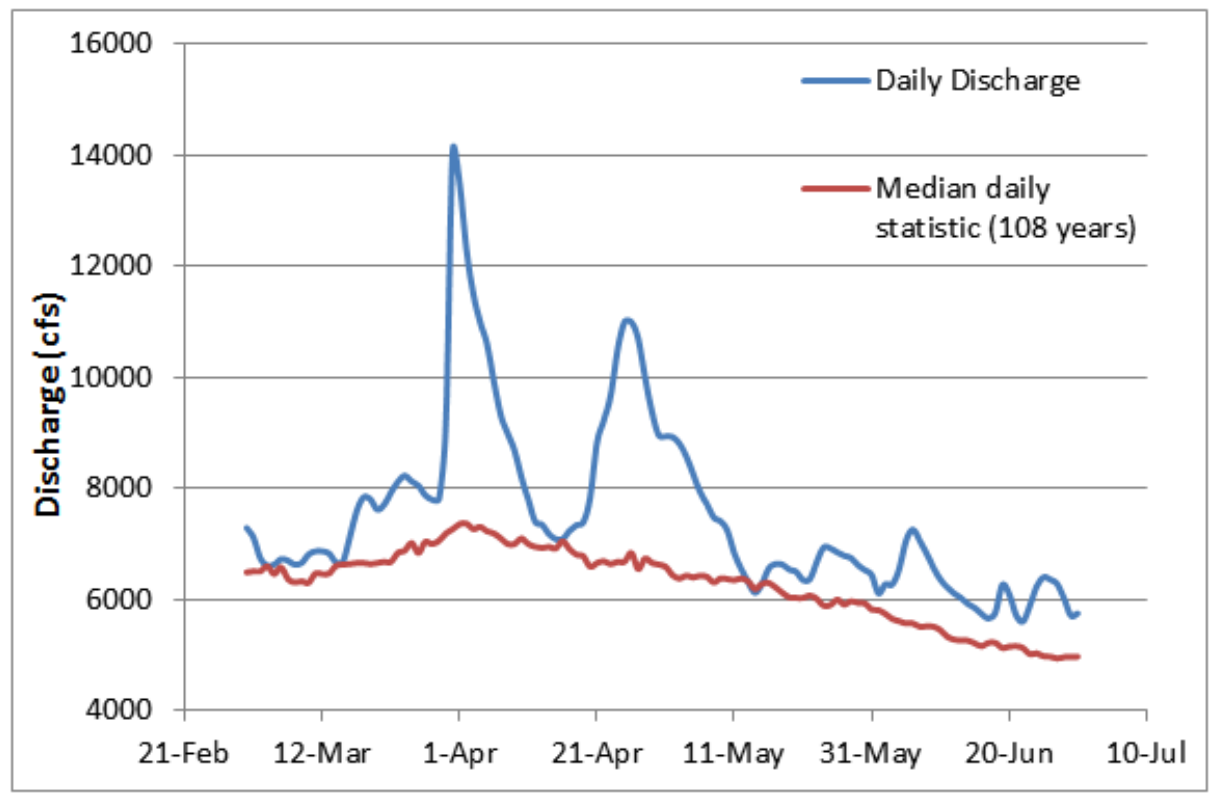

Figure 3.1. Daily discharge and the 108-yr median daily statistic flow for March through June 2012, recorded by the U.S. Geological Survey gaging station (USGS 14103000) in the Deschutes River at Moody, Oregon.

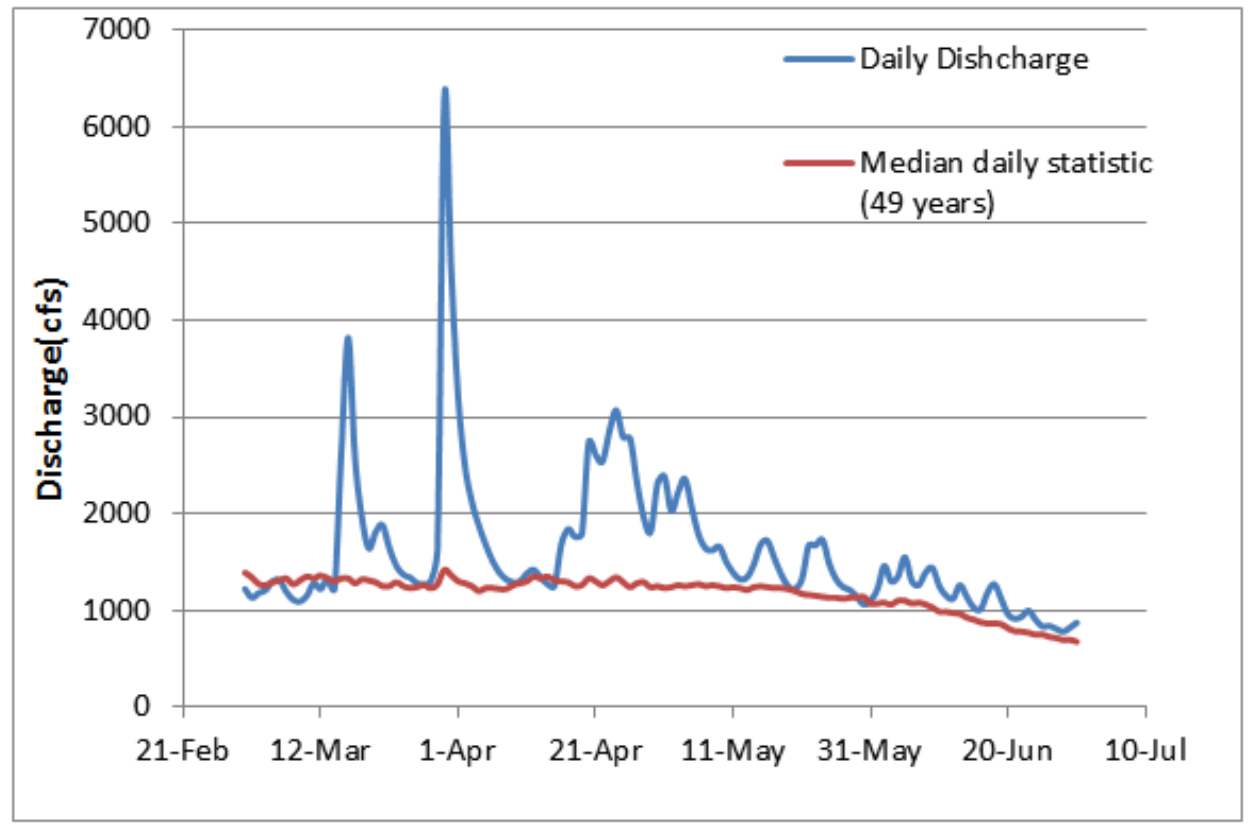

Figure 3.2. Daily and 49-yr median daily statistic discharge for March through June 2012, recorded by the U.S. Geological Survey gaging station (USGS 14120000) in the Hood River at Tucker Bridge, Oregon. 


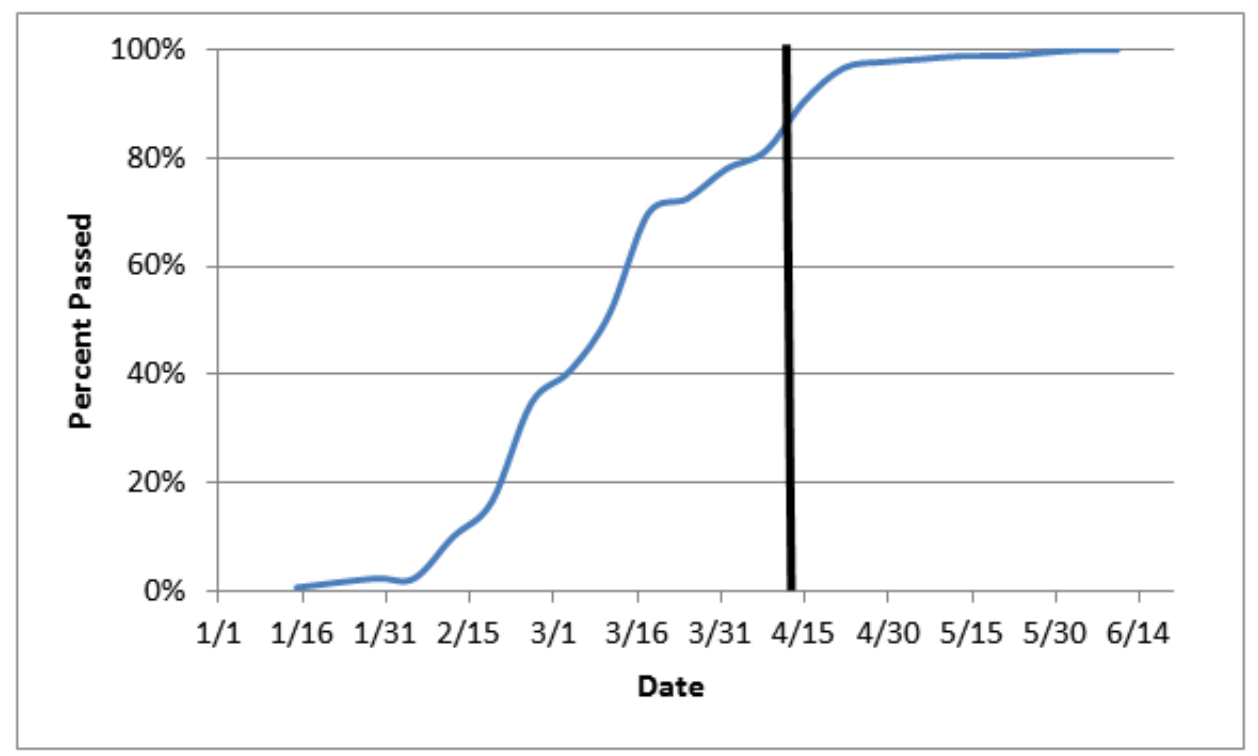

Figure 3.3. Cumulative proportion of downstream migrating kelts observed by date at the Deschutes River traps in 2012. The vertical line represents the first kelt tagging date.

\subsection{Fish Tagging}

Kelts were tagged with both a PIT tag and a JSATS acoustic tag (McMichael et al. 2010). The JSATS acoustic tag, measuring $12 \mathrm{~mm}$ long, $5.21 \mathrm{~mm}$ wide, and $3.77 \mathrm{~mm}$ thick, and weighing about $0.438 \mathrm{~g}$ in air and $0.29 \mathrm{~g}$ in water, had an average 32.2-d tag life and was programmed to transmit a coded signal once every $3 \mathrm{~s}$. The JSATS tag was glued and then shrink-wrapped into tubing attached to a 35-mm-long Floy T-bar tag (FD-94 EX-Wide T). The final size of the acoustic/Floy tag design was about $42 \mathrm{~mm}$ long (Figure 3.4). The integrity of the tag design was tested over a 70-d period in a tank of flowing water maintained at $10-12^{\circ} \mathrm{C}$. There were no instances where the tag combination dislodged from the surrogate tissue or components dislodged from each other. A Floy tagging gun was used to inject the T-bar anchor end of the Floy tag into the back musculature of the fish adjacent to its dorsal fin (Figure 3.5).

A PIT tag was injected into each kelt's dorsal sinus. PIT tags may be useful for evaluating repeat spawning runs over several years, whereas acoustic tag detections provided a precise tracking of downstream movements at several river sections and helped to delineate three-dimensional (3D) movement as the fish passed through the dams in 2012. PIT-tag detections on detectors in the BON JBS and B2CC provided additional route-of-passage information via the PIT Tag Information System database (http://www.ptagis.org/).

At remote tagging sites, the ODFW team did not have facilities to hold fish and could not know how many might have to be held after tagging and therefore opted not to use an anesthetic for tagging. Kelts were immediately returned to the creek after the procedure to resume their downstream migration. 


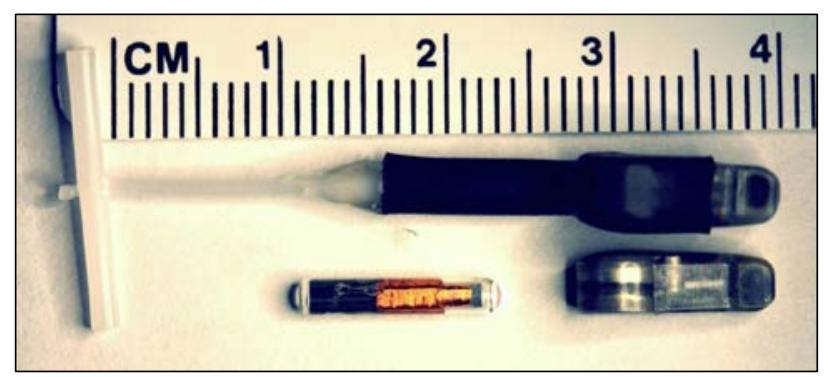

Figure 3.4. Picture showing a PIT tag, acoustic tag, and a Floy T-bar tag with an acoustic tag.
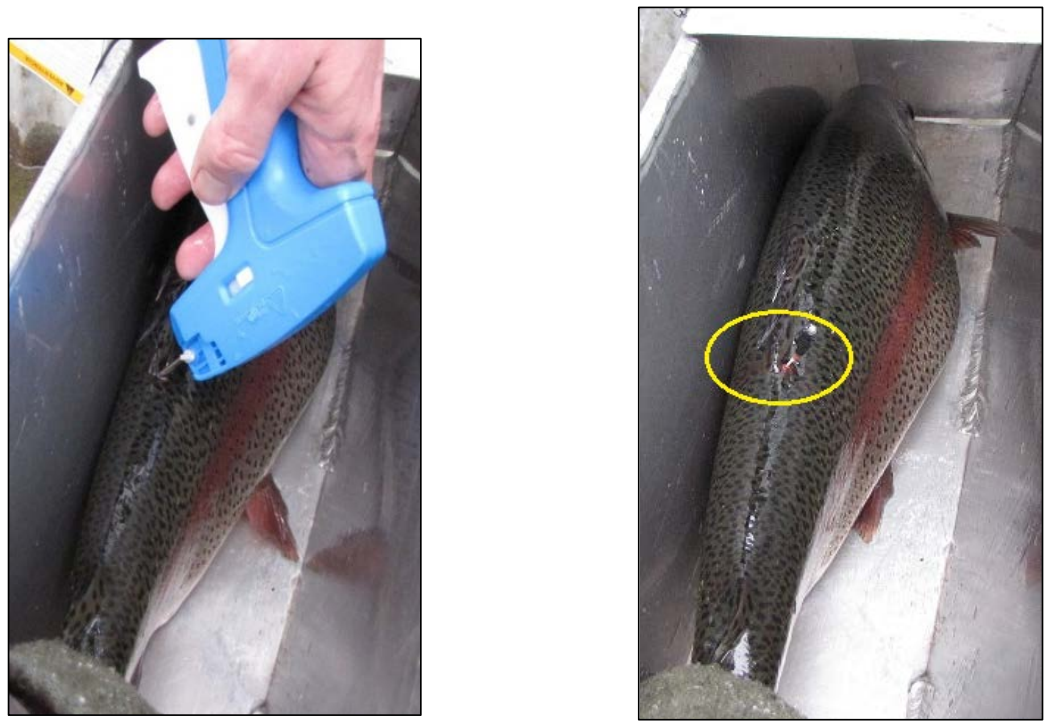

Figure 3.5. Floy tag injection using a tagging gun and a Floy T-bar tag after attachment.

\subsection{Fish Tagging and Handling Impacts}

Tagging had minimal effect on fish physiology because of the very short time period (usually a few seconds) required to attach the Floy tag. Kelts were immediately released after tagging, and this significantly reduced fish handling time. Very few, if any, fish were expected to be injured by handling or tagging effects. Acoustic tags used in this study had a transmitting frequency of $416.7 \mathrm{kHz}$, much higher than can be detected by fish or mammals, and therefore frequency should not harm salmonids. Hydrophones and rigging were designed without sharp edges and were not likely to contribute to fish injury. Fish collection, handling, holding, and transport were conducted by Oregon Department of Fish and Wildlife researchers in compliance with state and federal procedures for animal care and the humane treatment of vertebrates.

\subsection{Fish Condition}

Fish condition is a measure of fish health. The kelts collected for this study were visually evaluated to determine their spawning status, the presence of dorsal or body fungus, blindness, activeness, and/or body scars. Each condition category was graded using a numerical score of 1, 2, or 3 to describe overall condition (Table 3.1). For example, a kelt condition recorded as 311131 indicates a spawned kelt with no 
fungus on its body or dorsal surface, was not blind, was energetic, and had body scars. Condition data were summed to determine if a fish was in good, fair, or poor condition.

Table 3.1. Fish condition classifications.

\begin{tabular}{lccc}
\hline \multicolumn{1}{c}{ Condition } & 1 & 2 & 3 \\
\hline Spawning & Gravid & Intermediate & Spawned \\
Fungus & No fungus & $<20 \%$ fungus & $>20 \%$ fungus \\
Dorsal fungus & No dorsal fungus & With dorsal fungus & \\
Blindness & Not blind & Blind one eye & Blind both eyes \\
Activeness & Stiff & Lethargic not stiff & Energetic \\
Body scars & With body scars & No body scars & \\
\hline
\end{tabular}

Of the 58 kelts tagged, 55 were already spawned and 3 were observed to be in an intermediate spawning stage. Thirty of the kelts had no body fungus, while the remaining 28 had less than $20 \%$ fungus ( $\sim 48 \%)$; six kelts had dorsal fungus $(\sim 10 \%)$. Only two kelts were blind and both in only one eye. One of the 58 kelts was lethargic, and about $48.3 \%$ (28 of 58) had obvious scars. The decision was made a priori to tag all non-gravid kelt for this study. However, one reviewer questioned whether fish blind in one eye should have been tagged, so tagging criteria probably should be discussed with the Studies Review Work Group before future studies are implemented.

\subsection{Fish Release}

Immediately after being tagged, each kelt was released into the same river or creek where it was collected or trapped to resume downstream migration. Out of 58 kelts, 24 were tagged and released upstream of TDA, and the remaining 34 were tagged and released downstream of TDA. The proportion of kelts released at each tagging site is listed in Table 3.2. Mean outmigration travel time (mm:ss/rkm) was calculated by dividing the time interval from release to last detection by the migration distance. The number of kelt tagged and released at various sites in the Snake River and LCR are presented in comprehensive travel time and rate tables in Section 4.3.

Table 3.2. Number of kelts released by location and distance upstream from the mouth of the Columbia River.

\begin{tabular}{lcc}
\hline \multicolumn{1}{c}{ River/ Creek } & $\begin{array}{c}\text { Release Location } \\
\text { (CR rkm) }\end{array}$ & $\begin{array}{c}\text { Kelts } \\
\text { Release }\end{array}$ \\
\hline Bakeoven Creek & 411 & 7 \\
Buck Hollow Creek & 397 & 17 \\
Fifteenmile Creek & 309 & 14 \\
Neal Creek & 280 & 2 \\
Hood River & 273 & 18 \\
\hline
\end{tabular}




\subsection{Tagged Fish Detection}

Two types of JSATS array systems - autonomous array systems and cabled array systems - were deployed along the river reach to detect acoustic-tagged kelts passing downstream from the release sites. The first autonomous array was at Celilo, Oregon, at CR325; the most downriver array was at Kalama, Washington, at CR113. The last detections on TDA and BON dam-face cabled arrays were used to create a virtual release for kelts passing through the respective dams. The route of passage for this virtual release was estimated using 3D tracking and last detection time algorithms developed using high-level programming languages, including MATLAB (MATrix LABoratory) and the Statistical Analysis System (SAS). The components of the JSATS array system from the point of tag detection to data acquisition are shown in Figure 3.6.

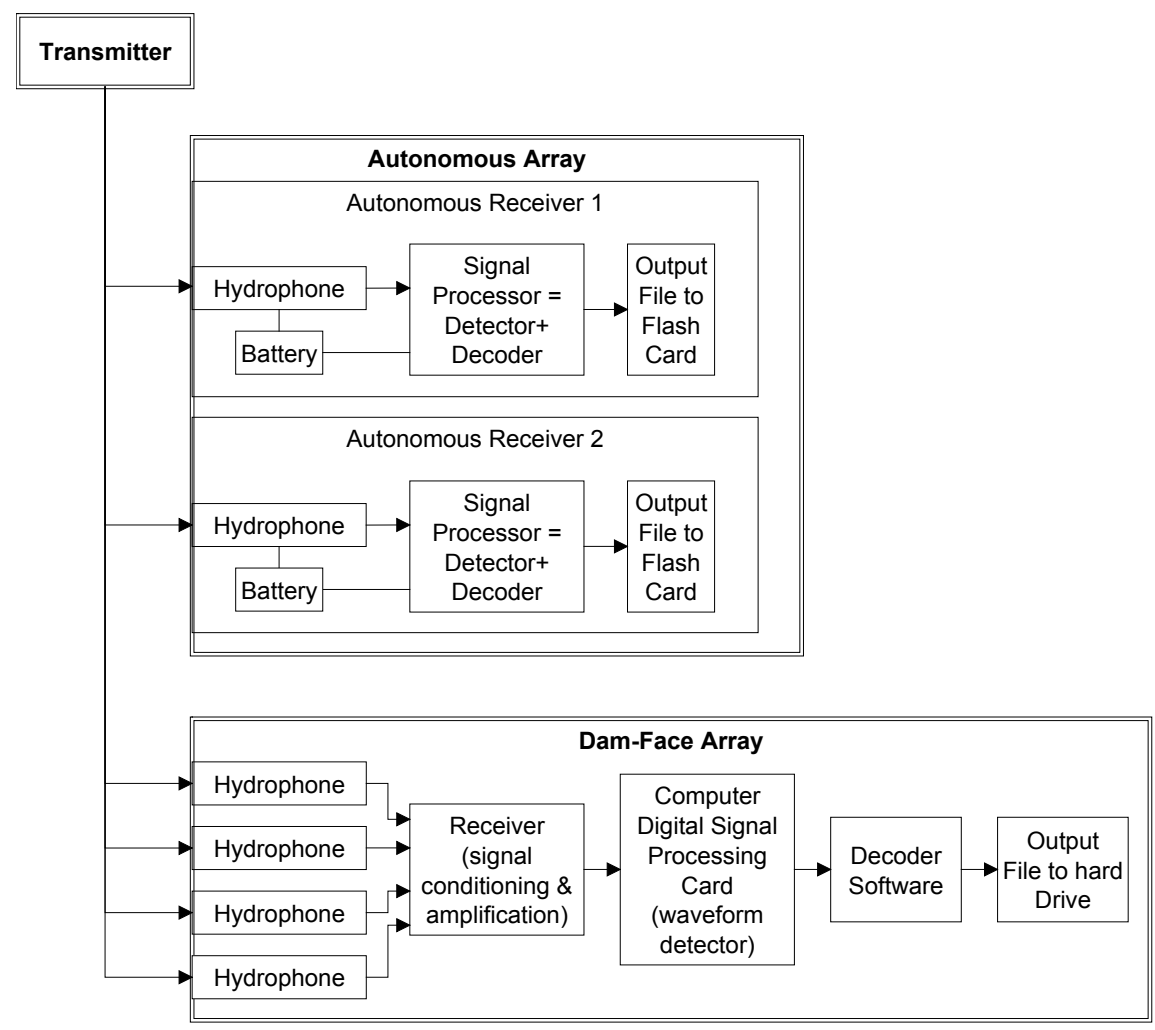

Figure 3.6. Flow chart showing JSATS array components.

\subsubsection{Cabled Dam-Face Array}

The cabled dam-face receiver system used for the study was designed by PNNL for CENWP. Each cabled receiver system includes a computer, data-acquisition software, digital signal-processing cards with field-programmable logic gate arrays (DSP+FPGAs), a global positioning system card, a fourchannel signal-conditioning receiver with gain control, hydrophones, and cables. The software that controls data acquisition and signal processing is the property of the CENWP.

JSATS dam-face cabled arrays were deployed along the upstream dam faces of TDA and BON to detect acoustic-tagged kelts approaching and passing through the dams. The dam-face cabled array consisted of 21 cabled receiver systems at TDA and 23 cabled receiver systems at BON. Generally, each 
cabled receiver system was connected to four hydrophones that were deployed on trolleys in pipes attached to the main piers at the powerhouse and spillway in a known fixed geometry. Hydrophones on each system alternated between shallow and deep deployments on adjacent piers and were interwoven with hydrophones from another system (Figure 3.7) to provide redundancy and to create two independent arrays for estimating the overall detection efficiency of the combined array. The resulting geometry of the hydrophone arrays also increased the accuracy of 3D tracking of kelts approaching dam passage routes.

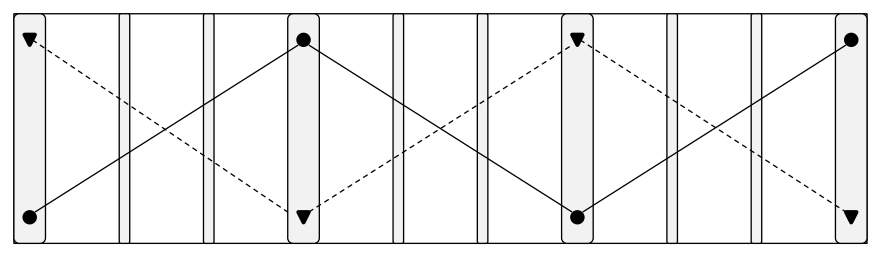

Figure 3.7. Front view of a zigzag hydrophone deployment at three turbines to form two independent detection arrays. The circles denote hydrophones of Array 1 and triangles denote hydrophone of Array 2.

\subsubsection{Autonomous Nodes and Arrays}

An autonomous array is a group of autonomous nodes deployed across the entire width of a river cross section to detect passing fish bearing acoustic tags (Weiland et al. 2009). Each autonomous node consists of a hydrophone attached to a housing, which holds a data processing circuit board, a compact flash card, battery, and USB cable connectors (Figure 3.8). Most arrays were deployed within $150 \mathrm{~m}$ of each other and less than $50 \mathrm{~m}$ from shore. Five autonomous arrays were deployed for this study. From upstream to downstream, the arrays were located near Celilo, Oregon (CR325); the BON forebay (CR236); the BON tailrace (CR233); near Knapp, Washington (CR156); and near Kalama, Washington (CR113).

Each autonomous array was named by concatenating letters and numbers indicating its position in the river reach. For example, array A1CR325 is the concatenation of "A" (for autonomous node), a sequential array number (counting from upstream to downstream), "CR" (representing Columbia River), and 325 , the nearest river kilometer to the array site.

The autonomous arrays located in the BON forebay and tailrace, just a few kilometers upstream and downstream from the dam face, were used for determining forebay residence and tailrace egress time for kelts migrating through the dam. Forebay residence time was calculated from the time elapsed between first detection at a forebay entrance array and the last detection on the dam-face cabled array. Tailrace egress time was calculated from the time elapsed between the last detection at a dam-face cabled array and the last detection on the tailrace autonomous array. Methods for deploying, retrieving, and servicing the autonomous nodes are the same as those used in 2011 for monitoring juvenile salmonid passage through dams on the lower Columbia River (Weiland et al. 2013). 

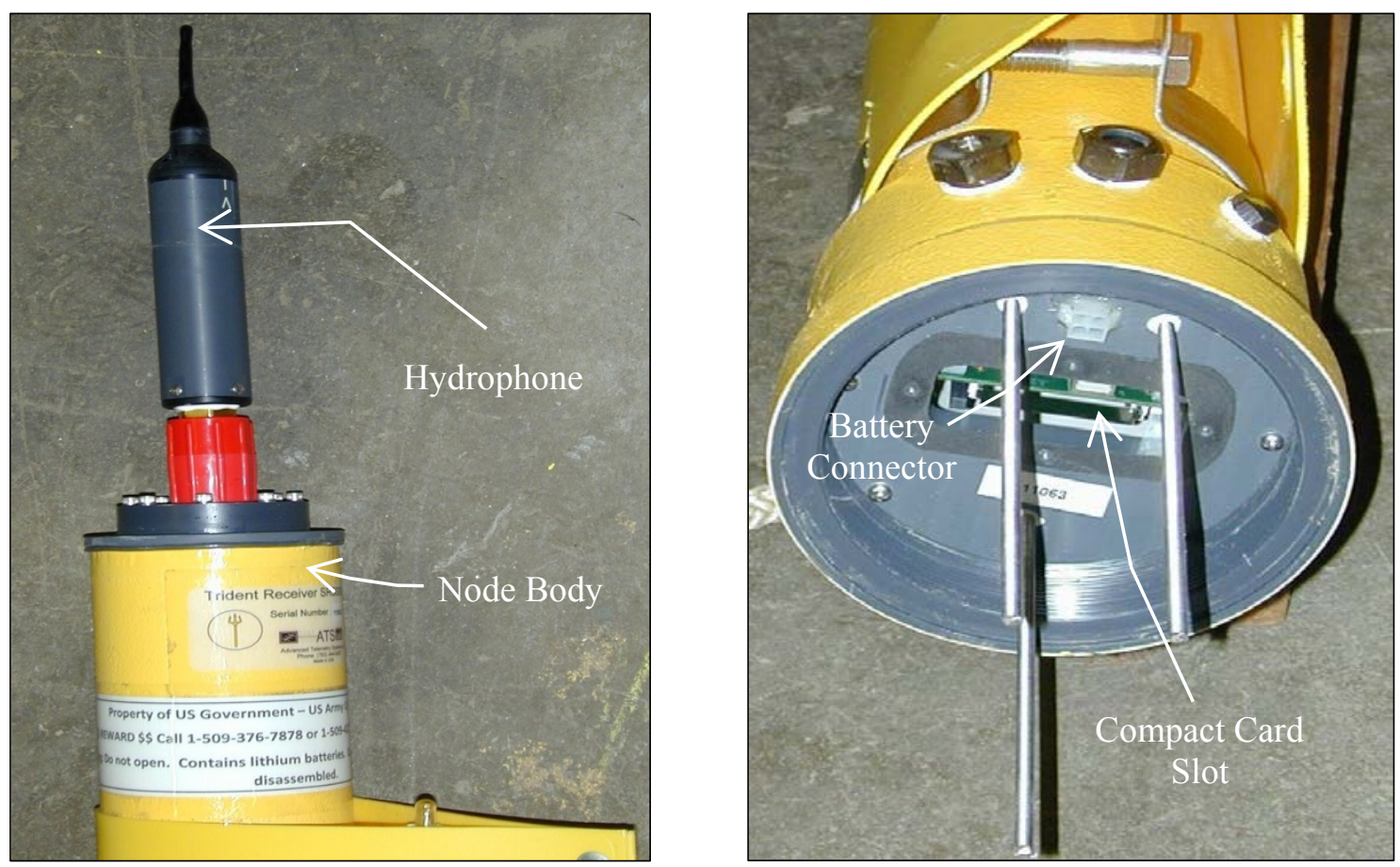

Figure 3.8. Autonomous node configuration with a hydrophone attached at the top of the node body (left), and a view of the node bottom (right) where a removable battery compartment would be attached.

\subsection{Data Processing and Validation}

Data processing and validation efforts included signal decoding and filtering, and a tag-life study.

\subsubsection{Signal Decoding and Filtering}

Data collected by the JSATS cabled hydrophones are encoded candidate messages saved in binary time-domain waveform (.bwm) files. A waveform decoding utility developed by the CENWP and PNNL was used to process the files. This decoding utility identifies valid tag signals and computes the tag code and time of arrival using Binary Phase Shift keying. Binary Phase Shift keying is a digital modulation technique that transmits messages by altering the phase of the carrier wave. The JSATS waveform utility decodes and stores detected signals onsite in real time in a computer hard drive connected to a series of cabled array systems. These hard drives were swapped every 2 weeks during the study. Raw data not decoded onsite (due to the incoming signals overloading the decoder) were decoded later by PNNL staff in the North Bonneville field office. One researcher was assigned to each dam to monitor JSATS data acquisition and verify proper functioning of data-acquisition systems daily. An algorithm developed using SAS was executed to identify gaps in decoded data. Data gaps, if any, were closely scrutinized to determine whether they were real or resulted from incomplete decoding of waveforms. System log notes recorded by staff during regular system checks were useful diagnostic tools. Waveform data collected during apparent gaps were reprocessed to recreate missing files of decoded data. False positive detections were excluded using MATLAB and SAS filtering algorithms applied to the raw decoding utility results. 
The following steps were used to filter raw cabled array and autonomous node data to produce clean detection data sets:

- Assume any decodes of the same tag occurring within $0.156 \mathrm{~s}$ of the previous decode to be multipath and delete them.

- Delete invalid detection events. A detection event is valid when the time interval between any four identical decodes is $\leq 47.8 \mathrm{~s}$ (3-s tags).

- Delete decodes found to be within valid detection events, as described above, if the time interval from the original decode in the series does not closely match an even multiple of one of the modes of the estimated pulse-repetition interval.

- Flag as orphans any remaining detection events for tag codes not used during the study in the hope of explaining their presence at a later date. Do not use flagged detections in any analysis unless they are explained. Resources for identifying used tag codes include the current code list of tags implanted in fish, codes of beacons deployed on autonomous nodes or in forebays, and coordination with other researchers in the basin to determine codes from concurrent studies.

- Flag detections that occur before a tag was released, at sites upstream of the listed release location, or on upstream arrays after a series of detections on the downstream arrays. Do not use flagged detections in any analysis unless the spatial or temporal discrepancies are adequately explained and resolved.

\subsubsection{Tag-Life Analysis}

All tags used for this study were delivered prior to the beginning of tagging (April 12, 2012), and these tags were from the same manufacturing lot as tags used in compliance survival studies of juvenile steelhead in 2012. We used results from the tag-life study conducted on 100 tags randomly selected from the lot used for tagging juvenile steelhead (see Skalski et al. 2013c) to determine whether tag-life corrections were necessary.

\subsection{Supplementing Sample Sizes by Regrouping Snake River Kelts}

A similar large-scale survival study was conducted by PNNL researchers in the Snake River (SR) for the USACE, Walla Walla District. It involved the tagging and release of 324 steelhead kelts at Lower Granite Dam (LGR) and several tributary sites upstream of LGR (Colotelo et al. 2013). Captured fish were surgically implanted with a 4.2-s JSATS acoustic tag and a PIT tag. The field study period was from April 18 through August 31, 2012, and included four SR dams-LGR at SR rkm 695, Lower Goose Dam at SR rkm 635, Lower Monumental Dam at SR rkm 589, and Ice Harbor Dam at SR rkm 538 - and four Columbia River Dams-McNary Dam at CR470, John Day Dam at CR349, TDA at CR309, and BON at CR234.

Because of sample size limitations, SR kelts (kelts tagged and released in the Snake River basin) that were detected at TDA and the BON dam-face array were regrouped with kelts detected at the respective dams from our study (i.e., LCR kelts) to form a virtual-release group of all kelts and thereby increase the precision of estimates of passage efficiency, effectiveness, and survival. 


\subsection{Survival Estimates}

The main focus of the study was to determine route-specific passage proportions and survival rates for the kelts. Survival was estimated using a virtual single-release model employing TagPro and Active Tag Life Adjusted Survival (ATLAS) software (Lady et al. 2010). ATLAS 1.5.3 was developed by the School of Aquatic and Fisheries Science, University of Washington, to analyze the survival of acoustictagged migrating smolts in the Columbia River Basin. ATLAS can eliminate survival bias due to tag failure by providing a tag-life correction, and is widely used in smolt and adult fish passage survival studies in the Columbia River basin. For determining survival estimates, ATLAS requires the capture history data containing acoustic-tag detection details from all downstream survival detection arrays. These capture history data are generated by the TagPro utility (http://www.cbr.washington.edu/telem/).

A tag-life analysis was done to determine whether tag-life corrections would be necessary for Cormack, Jolly, Seber (CJS) estimates of dam passage and route-specific survival rates for virtual releases of LCR kelts, SR kelts, and pooled virtual releases of SR and LCR kelts passing through the two dams. Route-specific survival estimates for TDA were determined for the powerhouse, spillway, turbines, and sluiceway passage routes. For BON, route-specific survival estimates were determined for kelts passing through B1, B1 turbines, the B1 sluiceway, the spillway, B2, B2 turbines, the B2 JBS, and the B2CC.

Kelts detected at the dam-face array were regrouped to form a virtual single-release group for estimating survival rates at the next downstream detection array. For kelt survival estimates through TDA, the BON cabled array (CR234) was used as the primary survival detection array and autonomous arrays at CR156 and CR113 were used as the secondary and tertiary survival detection arrays. For kelt survival estimates through BON, the autonomous node arrays at CR156 and CR113 were used as primary and secondary survival detection arrays, respectively. Capture history probabilities for primary and secondary survival detection arrays were as follows:

- $00=$ not detected on the primary or secondary arrays

- $10=$ detected on a primary array but not on the secondary array

- $01=$ not detected on the primary array but detected on the secondary array

- $11=$ detected on the primary and the secondary arrays.

The use of primary survival detection arrays $75 \mathrm{~km}$ downstream of TDA and $78 \mathrm{~km}$ downstream of BON were predicated on minimizing the probability of detecting dead tagged kelts to avoid upwardly biasing survival estimates. The tailrace array at BON was not used to estimate survival for the same reason.

\subsection{Estimating Dam Passage Time and Passage Metrics}

In this section, we describe estimators for forebay residence time, tailrace egress time, FPE, SPE, and the efficiency of SFOs (i.e., TDA sluiceway, B1 sluiceway, B2CC) as well as measures of passage effectiveness for the spillways and SFOs. Efficiency is defined as the proportion of fish passing through a dam by a specific route (e.g., the spillway or a sluiceway), and efficiency can be relative to a dam (e.g., SPE) or relative to an adjacent powerhouse. As examples, TDA sluiceway passage efficiency can be relative to TDA or to the TDA powerhouse, and $\mathrm{B} 2 \mathrm{CC}$ passage efficiency can be relative to $\mathrm{BON}$ or to 
B2. Effectiveness is the ratio of the proportion of fish to the proportion of water passing through a dam by a specific route.

\subsubsection{Forebay Residence Time}

Forebay residence time (h) was calculated by subtracting the time of first detection on the BON forebay entrance array from the time of last detection on the BON dam-face array. Forebay residence times could not be estimated for kelts passing through TDA because a forebay array was not deployed in spring 2012. The median and standard error of the mean were considered the best statistics for describing the forebay residence time for populations of tagged kelts passing through BON (LCR, SR, and LCR and SR pooled). Mean forebay residence time can be biased high by a few kelts that held for long periods in the forebay.

\subsubsection{Tailrace Egress Time}

Tailrace egress time (h) was calculated by subtracting the time of last detection on the BON dam-face array from the time of last detection on the BON tailrace array. Tailrace egress times could not be estimated for kelts passing through TDA because no tailrace detection array was deployed in spring 2012. The median and standard error of the mean were considered the best statistics for describing tailrace egress times for populations of tagged kelts passing through BON (LCR, SR, and all kelts). Mean tailrace egress time may be biased high by a few kelts that delayed for long periods in the BON JBS.

\subsubsection{Fish Passage Efficiency}

Fish passage efficiency is defined as the proportion of kelts passing through the dam via non-turbine routes such as the spillway or a SFO. For TDA, FPE was estimated as

$$
\widehat{\mathrm{FPE}}=\frac{\hat{N}_{S P}+\hat{N}_{S L}}{\hat{N}_{S P}+\hat{N}_{S L}+\hat{N}_{T}},
$$

where $\widehat{\text { FPE }}$ is estimated FPE, $\hat{N}_{i}$ is the estimated abundance of kelts passing through the $i$ th route $(\underline{i}=$ spillway [SP], sluiceway [SL], or turbines [T]). The variance of TDA $\widehat{F P E}$ was estimated as

$$
\operatorname{Var}(\widehat{\mathrm{FPE}})=\frac{\widehat{\mathrm{FPE}}(1-\widehat{\mathrm{FPE}})}{\sum_{i=1}^{3} \hat{N}_{i}}
$$

where Var is the variance of a binomial in terms and subscripts described for Equation (3.1). The double array on the dam face of TDA was shown to be $100 \%$ efficiency for over 5,700 fish detected there in a 2012 compliance study (Skalski et al. 2013b). 
For BON, FPE was estimated as

$$
\widehat{\mathrm{FPE}}=\frac{\hat{N}_{B 1 S L}+\hat{N}_{S P}+\hat{N}_{B 2 C C}+\hat{N}_{B 2 J B S}}{\hat{N}_{B 1 S L}+\hat{N}_{B 1 T}+\hat{N}_{S P}+\hat{N}_{B 2 C C}+\hat{N}_{B 2 J B S}+\hat{N}_{B 2 T}},
$$

where $\hat{N}_{i}$ is the estimated abundance of kelts passing through the $i$ th route $(\underline{i}=\mathrm{B} 1$ sluiceway [B1SL], spillway [SP], B2CC [B2CC], B2 JBS [B2JBS], B1 turbines [B1T], or B2 turbines [B2T]). The variance of BON $\widehat{\mathrm{FPE}}$ was estimated as

$$
\operatorname{Var}(\widehat{\mathrm{FPE}})=\frac{\mathrm{FPE}(1-\mathrm{FPE})}{\sum_{i=1}^{6} N_{i}}
$$

where Var is the variance of a binomial in terms and subscripts described for Equation (3.3). The double array on the dam face of BON was 100\% efficient for over 3,300 fish in a 2012 compliance study (Skalski et al. 2013a).

Double-array detection probabilities were $100 \%$ for every route of passage through TDA and BON, so raw counts of fish by route did not have to be adjusted to estimate absolute numbers, and variances could be estimated from Equations (3.2) and (3.4), which consider only the first terms of the original variance equation, based on a binomial sampling model.

FPE also can be estimated as non-turbine passage relative to passage through a powerhouse (e.g., the TDA powerhouse FPE $=\hat{N}_{S L} /\left(\hat{N}_{S L}+\hat{N}_{T}\right)$; B1 FPE $=\hat{N}_{B 1 S L} /\left(\hat{N}_{B 1 S L}+\hat{N}_{B 1 T}\right)$; and B2 FPE $=\left(\hat{N}_{B 2 C C}\right.$ $\left.+\hat{N}_{B 2 J B S}\right) /\left(\hat{N}_{B 2 C C}+\hat{N}_{B 2 J B S}+\hat{N}_{B 2 T}\right)$. Variance estimators would be analogous to those shown in Equations (3.2) and (3.4), but terms would be limited to a single powerhouse.

\subsubsection{Spill Passage Efficiency}

Spill passage efficiency is defined as the fraction of fish passing through a dam via the spillway. For TDA, SPE was calculated as:

$$
\widehat{\mathrm{SPE}}=\frac{\hat{N}_{S P}}{\hat{N}_{S P}+\hat{N}_{S L}+\hat{N}_{T}}
$$

where $\widehat{\mathrm{SPE}}$ is estimated spill passage efficiency and $\hat{N}_{i}$ is the estimated abundance of acoustic-tagged fish through the $i$ th route ( $i=$ spillway [SP], sluiceway, [SL], or turbines [T]). The variance of $\widehat{\mathrm{SPE}}$ was estimated as

$$
\operatorname{Var}(\widehat{\mathrm{SPE}})=\frac{\widehat{\mathrm{SPE}}(1-\widehat{\mathrm{SPE}})}{\sum_{i=1}^{3} \hat{N}_{i}}
$$


where Var is the variance of a binomial in terms described for Equation (3.5).

Spill passage efficiency for BON was estimated by the fraction

$$
\widehat{\mathrm{SPE}}=\frac{\hat{N}_{S P}}{\hat{N}_{B 1 S L}+\hat{N}_{B 1 T}+\hat{N}_{S P}+\hat{N}_{B 2 C C}+\hat{N}_{2 J B S}+\hat{N}_{B 2 T}},
$$

where $\widehat{\mathrm{SPE}}$ is the estimated spill passage efficiency and $\hat{N}_{i}$ is the estimated abundance of acoustic-tagged fish through the $i$ th route ( $i=\mathrm{B} 1$ sluiceway [B1SL], B1 turbines [B1T], spillway [SP], B2CC [B2CC], $\mathrm{B} 2 \mathrm{JBS}[\mathrm{B} 2 \mathrm{JBS}]$, and $\mathrm{B} 2$ turbines [B2T]). The variance of $\widehat{\mathrm{SPE}}$ was estimated as

$$
\operatorname{Var}(\widehat{\mathrm{SPE}})=\frac{\operatorname{SPE}(1-\mathrm{SPE})}{\sum_{i=1}^{6} N_{i}}
$$

where Var is the variance of a binomial.

\subsubsection{Sluiceway Passage Efficiency Relative to the Dam}

Sluiceway passage efficiency (SLE) for a dam is defined as the fraction of kelts passing through the dam via a SFO relative to the total number passing through the dam. For TDA, SLE was estimated by the fraction

$$
\widehat{S L E}=\frac{\hat{N}_{S L}}{\hat{N}_{S L}+\hat{N}_{S P}+\hat{N}_{T}}
$$

where $\hat{N}_{i}$ is the estimated abundance of acoustic-tagged fish through the $i$ th route ( $i=$ sluiceway [SL], spillway [SP], or turbines [T]). The variance of $\widehat{S L E}$ was estimated as

$$
\operatorname{Var}(\widehat{\mathrm{SLE}})=\frac{\widehat{\operatorname{SLE}}(1-\widehat{\mathrm{SLE}})}{\sum_{i=1}^{3} \hat{N}_{i}}
$$

where Var is the variance of a binomial.

For BON, the B1 sluiceway passage efficiency relative to the entire dam was estimated by the fraction

$$
\widehat{\mathrm{B} 1 \mathrm{SLE}}=\frac{\hat{N}_{B 1 S L}}{\hat{N}_{B 1 S L}+\hat{N}_{B 1 T}+\hat{N}_{S P}+\hat{N}_{B 2 C C}+\hat{N}_{B 2 T}+\hat{N}_{B 2 J B S}},
$$

where, terms were described previously for calculating BON FPE. 
The variance of $\widehat{\mathrm{B} 1 \mathrm{SLE}}$ was estimated as

$$
\operatorname{Var}(\widehat{\mathrm{B} 1 \mathrm{SLE}})=\frac{\mathrm{B} 1 \mathrm{SLE}(1-\mathrm{B} 1 \mathrm{SLE})}{\sum_{i=1}^{6} N_{i}}
$$

where Var is the variance of a binomial.

The B2CC passage efficiency relative to the entire dam was estimated by the fraction

$$
\widehat{\mathrm{B} 2 \mathrm{CC}}=\frac{\hat{N}_{B 2 C C}}{\hat{N}_{B 1 S L}+\hat{N}_{B 1 T}+\hat{N}_{S P}+\hat{N}_{B 2 C C}+\hat{N}_{B 2 T}+\hat{N}_{B 2 J B S}},
$$

where terms were described previously for calculating BON FPE.

The variance of $\mathrm{B} 2 \mathrm{CC}$ passage efficiency was estimated as

$$
\operatorname{Var}(\widehat{\mathrm{B} 2 \mathrm{CC}})=\frac{\widehat{\mathrm{B} 2 \mathrm{CC}}(1-\widehat{\mathrm{B} 2 \mathrm{CC}})}{\sum_{i=1}^{6} N_{i}}
$$

where Var is the variance of a binomial.

\subsubsection{Sluiceway Passage Efficiency Relative to an Adjacent Powerhouse}

Sluiceway passage efficiency relative to an adjacent powerhouse (SLE $E_{\mathrm{PH}}$ ) is the passage efficiency for an SFO relative to total numbers passing through the adjacent powerhouse. For TDA, SLE $\mathrm{PH}_{\mathrm{P}}$ was estimated by the fraction

$$
\widehat{\mathrm{SLE}_{\mathrm{PH}}}=\frac{\hat{N}_{S L}}{\hat{N}_{S L}+\hat{N}_{T}}
$$

where terms were described previously for Equation (3.1) above. The variance of $\widehat{\mathrm{SLE}_{\mathrm{PH}}}$ was estimated as

$$
\operatorname{Var}\left(\widehat{\mathrm{SLE}_{\mathrm{PH}}}\right)=\frac{\widehat{\mathrm{SLE}_{\mathrm{PH}}}\left(1-\widehat{\mathrm{SLE}_{\mathrm{PH}}}\right)}{\sum_{i=1}^{2} N_{i}}
$$

where Var is the variance of a binomial.

For the BON B1 B1SLE $E_{\mathrm{B} 1}$ was estimated as estimated by the fraction 


$$
\widehat{\mathrm{B} 1 \mathrm{SLE}_{\mathrm{B} 1}}=\frac{\hat{N}_{B 1 S L}}{\hat{N}_{B 1 S L}+\hat{N}_{B 1 T}},
$$

The variance of $\widehat{\mathrm{B} 1 \mathrm{SLE}_{\mathrm{B} 1}}$ was estimated as

$$
\operatorname{Var}\left(\widehat{\mathrm{B} 1 \mathrm{SLE}_{\mathrm{B} 1}}\right)=\frac{\widehat{\mathrm{B} 1 \mathrm{SLE}_{\mathrm{B} 1}}\left(1-\widehat{\mathrm{B} 1 \mathrm{SLE}_{\mathrm{B} 1}}\right)}{\sum_{i=1}^{2} N_{i}},
$$

where Var is the variance of a binomial.

The $\mathrm{B} 2 \mathrm{CC}$ passage efficiency relative to $\mathrm{B} 2\left(\mathrm{~B} 2 \mathrm{CC}_{\mathrm{B} 2}\right)$ was estimated by the fraction

$$
\widehat{\mathrm{B} 2 \mathrm{CC}} \mathrm{B2}=\frac{\hat{N}_{B 2 C C}}{\hat{N}_{B 2 C C}+\hat{N}_{B 2 J B S}+\hat{N}_{B 2 T}},
$$

The variance of $\widehat{\mathrm{B} 2 \mathrm{CC}_{\mathrm{B} 2}}$ was estimated as

$$
\operatorname{Var}\left(\widehat{\mathrm{B} 2 \mathrm{CC}_{\mathrm{B} 2}}\right)=\frac{\widehat{\mathrm{B} 2 \mathrm{CC}_{\mathrm{B} 2}}\left(1-\widehat{\mathrm{B} 2 \mathrm{CC}_{\mathrm{B} 2}}\right)}{\sum_{i=1}^{3} N_{i}}
$$

where Var is the variance of a binomial.

\subsubsection{Spill Passage Effectiveness}

Passage effectiveness is defined as the proportion of fish passing through a particular route divided by the proportion of volume of water flowing through that route. The spill passage effectiveness at BON was estimated by the quantity

$$
\widehat{S P N}=\frac{\left(\frac{\hat{N}_{S P}}{\widehat{N S P}+\hat{N}_{S P}}\right)}{\frac{\left(\hat{V}_{S P}\right)}{V_{T}}}=\widehat{S P E} \cdot \frac{V_{T}}{V_{S P}},
$$

where

$$
\begin{aligned}
& \hat{N}_{S P}=\text { spill passage } \\
& \widehat{N S P}=\widehat{N_{B 1 S L}}+\widehat{N_{B 1 T}}+\widehat{N_{B 2 C C}}+\widehat{N_{B 2 J B S}}+\widehat{N_{B 2 T}}=\text { (non-spill passage) } \\
& V_{S P}=\text { volume of water spilled } \\
& V_{T}=\text { total volume of water passing through the dam } \\
& \text { during the period of inference }
\end{aligned}
$$




$$
\widehat{S P E}=\text { spill passage efficiency. }
$$

The variance of $\widehat{S P N}$ can be estimated by

$$
\widehat{\operatorname{Var}}(\widehat{S P N})=\left(\frac{V_{T}}{V_{S}}\right)^{2} \cdot \widehat{\operatorname{Var}}(\widehat{S P E})
$$

Spill passage effectiveness and its variance for TDA would be calculated similarly. The only difference is in the definition of $\widehat{N S P}$, which for TDA would be $\widehat{N S P}=\widehat{N_{S L}}+\widehat{N_{T}}$, where $\widehat{N_{S L}}$ is the number passing through the sluiceway and $\widehat{N_{T}}$ is the number passing through the turbines.

\subsubsection{Sluiceway Passage Effectiveness}

For TDA, sluiceway passage effectiveness relative to the entire dam was estimated by the quantity

$$
\widehat{S L N}=\frac{\left(\frac{\hat{N}_{S L}}{\widehat{N S L}+\hat{N}_{S L}}\right)}{\frac{\left(\hat{V}_{S L}\right)}{V_{T}}}=\widehat{S L E} \cdot \frac{V_{T}}{V_{S L}}
$$

where

$$
\begin{aligned}
\hat{N}_{S L}= & \text { sluiceway passage } \\
\widehat{N S L}=\widehat{N_{S P}}+\widehat{N_{T}=} \text { (non-sluiceway passage, i.e., through the spillway and turbines, } & \text { respectively) } \\
V_{S L}= & \text { volume of water passed through the sluiceway } \\
V_{T}= & \text { total volume of water passing through the dam during the period of } \\
\widehat{S L E}= & \text { inference }
\end{aligned}
$$

The variance of $\widehat{S L N}$ can be estimated by

$$
\widehat{\operatorname{Var}}(\widehat{S L N})=\left(\frac{V_{T}}{V_{S}}\right)^{2} \cdot \widehat{\operatorname{Var}}(\widehat{S L E})
$$

For TDA, sluiceway passage effectiveness relative to the powerhouse was estimated by the quantity

$$
\widehat{S L N_{P H}}=\frac{\left(\frac{\hat{N}_{S L}}{\hat{N}_{T}+\hat{N}_{S L}}\right)}{\frac{\left(\hat{V}_{S L}\right)}{V_{P H}}}=\widehat{S L E_{P H}} \cdot \frac{V_{P H}}{V_{S L}}
$$


where $\quad \hat{N}_{S L}=$ sluiceway passage

$$
\begin{aligned}
\widehat{N}_{T} & =\text { number passing through turbines } \\
\widehat{N}_{S L} & =\text { number passing through the sluiceway } \\
V_{S L} & =\text { volume of water passed through the sluiceway } \\
V_{P H} & =\text { total volume of water passing through the dam during the period of inference } \\
\widehat{S L E_{P H}} & =\text { sluiceway passage efficiency relative to the powerhouse. }
\end{aligned}
$$

The variance of $\widehat{S L N}$ can be estimated by

$$
\widehat{\operatorname{Var}}(\widehat{S L N})=\left(\frac{V_{T}}{V_{S}}\right)^{2} \cdot \widehat{\operatorname{Var}}\left(\widehat{S L E_{P H}}\right)
$$

For the BON B1 sluiceway, sluiceway passage effectiveness relative to the entire dam was estimated by the quantity

$$
\widehat{B 1 S L N}=\frac{\left(\frac{\hat{N}_{B 1 S L}}{\widehat{N B 1 S L}+\hat{N}_{B 1 S L}}\right)}{\frac{\left(\hat{V}_{B 1 S L}\right)}{V_{T}}}=\widehat{B 1 S L E} \cdot \frac{V_{T}}{V_{B 1 S L}}
$$

where

$$
\begin{aligned}
& \hat{N}_{B 1 S L}=\text { B1 sluiceway passage } \\
& \widehat{N B 1 S L}=\hat{N}_{B 1 T}+\hat{N}_{S P}+\hat{N}_{B 2 C C}+\hat{N}_{B 2 J B S}+\hat{N}_{B 2 T}=\text { (non-B1 sluiceway passage) } \\
& \hat{V}_{B 1 S L}=\text { volume of water passed through the } \\
& \text { B1 sluiceway } \\
& V_{T}=\text { total volume of water passing through the dam } \\
& \text { during the period of inference } \\
& \widehat{B 1 S L E}=\mathrm{B} 1 \text { sluiceway passage efficiency, as defined in } \\
& \text { Equation (3.11). }
\end{aligned}
$$

The variance of $\widehat{S L N}$ can be estimated by

$$
\widehat{\operatorname{Var}}(\widehat{S L N})=\left(\frac{V_{T}}{V_{S}}\right)^{2} \cdot \widehat{\operatorname{Var}}(\widehat{S L E})
$$


The B1 sluiceway passage effectiveness relative to B1 was estimated by the quantity

$$
\widehat{B 1 S L N_{B 1}}=\frac{\left(\frac{\hat{N}_{B 1 S L}}{\hat{N}_{B 1 T}+\hat{N}_{B 1 S L}}\right)}{\frac{\left(\hat{V}_{B 1 S L}\right)}{\hat{V}_{B 1}}}=\widehat{\mathrm{B} 1 \mathrm{SLE}_{\mathrm{B} 1}} \cdot \frac{\hat{V}_{B 1}}{\hat{V}_{B 1 S L}}
$$

where $\quad \hat{N}_{B 1 S L}=$ estimated number passing through the B1 sluiceway

$\widehat{N}_{B 1 T}=$ estimated number passing through B1 turbines

$V_{B 1 S L}=$ volume of water passed through the sluiceway

$V_{B 1}=$ total volume of water passing through the dam during the period of inference

$\widehat{B 1 S L E_{B 1}}=$ sluiceway passage efficiency relative to the $\mathrm{B} 1$ powerhouse.

The variance of $\widehat{B 1 S L N_{B 1}}$ can be estimated by

$$
\widehat{\operatorname{Var}}(\widehat{B 1 S L N})=\left(\frac{\hat{V}_{B 1}}{\hat{V}_{B 1 S L}}\right)^{2} \cdot \widehat{\operatorname{Var}}\left(\widehat{B 1 S L E_{B 1}}\right)
$$

BON B2CC passage effectiveness relative to the entire dam was estimated by the quantity

$$
\widehat{B 2 C C S L N}=\frac{\left(\frac{\hat{N}_{B 2 C C}}{\widehat{N B 2 C C}+\hat{N}_{B 2 C C}}\right)}{\frac{\left(\hat{V}_{B 2 C C}\right)}{\hat{V}_{T}}}=\widehat{B 2 C C} \cdot \frac{\hat{V}_{T}}{\hat{V}_{B 2 C C}}
$$

where

$$
\begin{aligned}
\widehat{N} \hat{N}_{B 2 C C}= & \text { estimated number passing through the B2CC } \\
\hat{N}_{B 2 C C} \hat{N}_{B 1 S L}+\hat{N}_{B 1 T}+\hat{N}_{S P}+\hat{N}_{B 2 J B S}+\hat{N}_{B 2 T} & \text { (non-B2CC kelt passage) } \\
\hat{V}_{B 2 C C}= & \text { estimated volume of water passed through the } \\
& \text { B2CC } \\
\hat{V}_{T}= & \text { estimated total volume of water passing through } \\
\text { the dam during the period of inference } & \text { estimated B1 sluiceway passage efficiency, as } \\
\widehat{B 2 C C}= & \text { defined in Equation (3.13). }
\end{aligned}
$$


The variance of $\widehat{B 2 C C S L N}$ can be estimated by

$$
\widehat{\operatorname{Var}}(\widehat{B 2 C C S L N})=\left(\frac{V_{T}}{V_{B 2 C C}}\right)^{2} \cdot \widehat{\operatorname{Var}}(\widehat{B 2 C C})
$$

B2CC sluiceway passage effectiveness relative to $\mathrm{B} 2$ was estimated by the quantity

$$
\overline{B 2 C C S L N_{B 2}}=\frac{\left(\frac{\hat{N}_{B 2 C C}}{\hat{N}_{B 2 C C}+\overline{\mathrm{NB}}_{\mathrm{CCC}}}\right)}{\frac{\left(\hat{V}_{B 2 C C}\right)}{V_{B 2}}}=\widehat{\mathrm{B} 2 \mathrm{CC}} \mathrm{B} 2 \cdot \frac{V_{B 2}}{V_{B 2 C C}}
$$

where $\quad \hat{N}_{B 2 C C}=$ estimated number passing through the B2CC

$$
\begin{aligned}
\widehat{N B 2 C C_{B 2}=} & \text { estimated number passing through } \mathrm{B} 2 \text { by non- } \mathrm{B} 2 \mathrm{CC} \text { routes (B2 JBS and } \\
& \mathrm{B} 2 \text { turbines) } \\
V_{B 2 C C}= & \text { estimated volume of water passed through the } \mathrm{B} 2 \mathrm{CC} \\
V_{B 2}= & \text { total volume of water passing through } \mathrm{B} 2 \text { during the period of inference } \\
\widehat{B 1 S L E_{B 1}}= & \text { sluiceway passage efficiency relative to the } \mathrm{B} 1 \text { powerhouse. }
\end{aligned}
$$

The variance of $\overline{\operatorname{B2CCSLN}_{B 2}}$ can be estimated by

$$
\widehat{\operatorname{Var}}\left(\widehat{B 2 C C S L N_{B 2}}\right)=\left(\frac{V_{B 2}}{V_{B 2 C C}}\right)^{2} \cdot \widehat{\operatorname{Var}}\left(\widehat{B 2 C C_{B 1}}\right) \text {. }
$$





\subsection{Results}

The study derived results related to survival and passage estimates, passage efficiency and effectiveness, forebay residence and tailrace egress time, and kelt condition and release, as described in the following sections.

\subsection{Dam Passage and Survival Estimates}

The following sections describe the number of kelts passing through various routes at TDA and BON and their associated survival rates.

\subsubsection{Tag-Life Corrections}

No tag-life corrections were required for SR or LCR kelt survival estimates described in this study. All surviving SR kelts implanted with 4.2-s acoustic tags passed the last survival detection array near Kalama, Washington (CR113) in $24.2 \mathrm{~d}$, and those tags had a minimum lifespan of $45.3 \mathrm{~d}$ (Colotelo et al. 2013). All surviving LCR kelts passed the last detection array near Kalama within $20 \mathrm{~d}$, and their attached 3-s acoustic tags lasted an average of $32.2 \mathrm{~d}$ (minimum $27.9 \mathrm{~d}$ ).

\subsubsection{The Dalles Dam Passage and Survival Estimates}

Of 24 LCR kelts released upstream of TDA in the Deschutes River Basin, only 14 (58.3\%) were detected at TDA on the dam-face cabled array. Of the 14 detected kelts, $10(71.4 \%)$ passed at the spillway and four $(28.6 \%)$ passed by powerhouse routes - two via the sluiceway and two through turbine units. A total of 177 kelts released in the Snake River Basin were detected at TDA on the dam-face cabled array; $149(84.2 \%)$ passed at the spillway, $12(6.8 \%)$ passed through the sluiceway, and $16(9.0 \%)$ passed through the turbines.

Sample sizes for LCR kelts detected at TDA were too small to provide accurate survival estimates, and had a large standard error. Pooling the virtual-release detections of LCR and SR kelts provided adequate samples sizes for estimating survival (Table 4.1). The dam passage survival rate for LCR kelts passing through TDA $(\mathrm{N}=14)$ was $0.750(\mathrm{SE}=0.1336)$; the upper $95 \%$ confidence interval $(\mathrm{CI})$ exceeded 1.00. The estimated survival rate for the $\mathrm{SR}$ kelts was $0.896(\mathrm{SE}=0.0249)$ (Table 4.1). The dam passage survival rate for pooled SR and LCR kelts was 0.883 ( $\mathrm{SE}=0.0252$ ). Passage survival rates for all kelts (SR and LCR kelts) indicate the best routes of passage at TDA included the sluiceway (0.931) and spillway (0.913), which had overlapping 95\% CIs (Figure 4.1). Passage survival for all SR and LCR kelts $(\mathrm{N}=16)$ through turbines was $0.533(\mathrm{SE}=0.1288)$, and this was significantly lower than the survival of kelts passing through the sluiceway or spillway. 
Table 4.1. Passage proportion and survival estimates with standard errors (SEs) for all kelts (combining SR kelts and LCR kelts), SR kelts, and LCR kelts through The Dalles Dam.

\begin{tabular}{|c|c|c|c|c|c|c|c|c|c|}
\hline Route & $\begin{array}{c}\text { All } \\
\text { Kelts } \\
(\mathrm{N})\end{array}$ & $(\%)$ & $\begin{array}{l}\text { Survival } \\
\text { (SE) }\end{array}$ & $\begin{array}{c}\text { SR } \\
\text { Kelts } \\
(\mathrm{N})\end{array}$ & $(\%)$ & $\begin{array}{l}\text { Survival } \\
\text { (SE) }\end{array}$ & $\begin{array}{c}\text { LCR } \\
\text { Kelts } \\
(\mathrm{N})\end{array}$ & $(\%)$ & Survival (SE) \\
\hline TDA Dam & 177 & & $\begin{array}{c}0.8829 \\
(0.0252)\end{array}$ & 163 & & $\begin{array}{c}0.8956 \\
(0.0249)\end{array}$ & 14 & & $\begin{array}{c}0.7500 \\
(0.1336)\end{array}$ \\
\hline Spillway & 149 & 84.18 & $\begin{array}{c}0.9132 \\
(0.0243)\end{array}$ & 139 & 85.28 & $\begin{array}{c}0.9394 \\
(0.0296)\end{array}$ & 10 & 71.43 & $\begin{array}{c}0.7000 \\
(0.1449)\end{array}$ \\
\hline Powerhouse & 28 & 15.82 & $\begin{array}{c}0.7185 \\
(0.0860)\end{array}$ & 24 & 14.72 & $\begin{array}{c}0.6942 \\
(0.1021)\end{array}$ & $4^{(\mathrm{a})}$ & 28.57 & $\begin{array}{c}0.7500 \\
(0.2165)\end{array}$ \\
\hline Turbine & 16 & 9.04 & $\begin{array}{c}0.5333 \\
(0.1288)\end{array}$ & 14 & 8.59 & $\begin{array}{c}0.5385 \\
(0.1383)\end{array}$ & 2 & 14.29 & \\
\hline Sluiceway & 12 & 6.78 & $\begin{array}{c}0.9308 \\
(0.0753)\end{array}$ & 10 & 6.13 & $\begin{array}{c}0.9333 \\
(0.1233)\end{array}$ & 2 & 14.29 & \\
\hline
\end{tabular}

(a) Among the four kelts passing through powerhouse, two of the kelts passing through sluiceway were detected below CR234, whereas only one of the kelts passing through the turbine was detected below CR234.

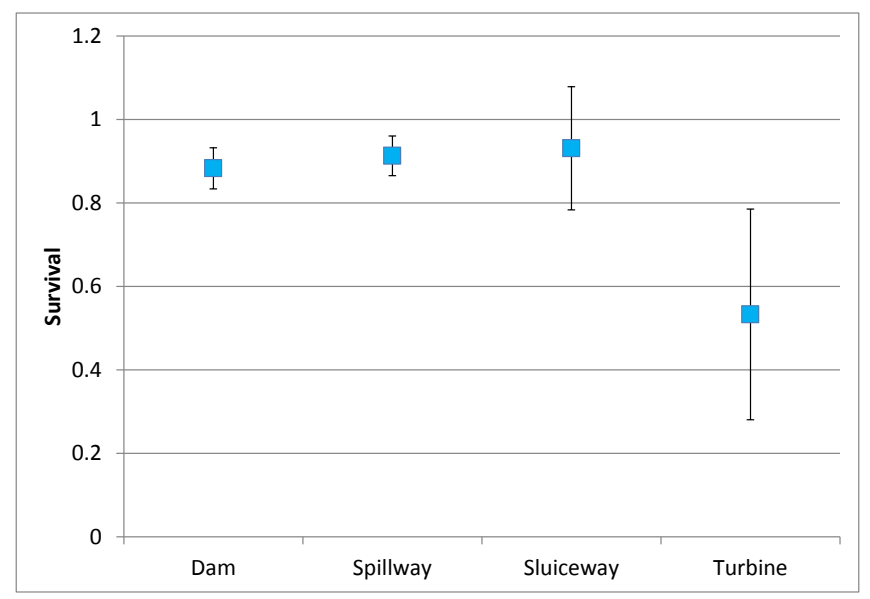

Figure 4.1. Survival estimates (with $95 \%$ CI) for all kelts through The Dalles Dam.

\subsubsection{Bonneville Dam Passage and Survival Estimates}

Kelts released upstream and downstream of TDA and detected by the BON dam-face cabled array were virtually regrouped, and their passage and survival rates through BON and $78 \mathrm{~km}$ of tailwater were estimated using a single-release CJS model. A total of 25 LCR kelts were detected at the BON dam face; 8 passed at B1 (32\%), 9 at the spillway (36\%), and 8 at B2 (32\%) (Table 4.2). Only 9 of 24 (37.5\%) LCR kelts released upstream of TDA and 16 of $34(47.1 \%)$ released downstream of TDA were detected at the BON dam face. At B1, five kelts passed through turbines (62.5\%), and three passed through the B1 sluiceway (37.5\%). Of the eight kelts passing through B2, passage was split between the B2CC (37.5\%), JBS (25\%), and turbines (37.5\%) (Table 4.3), so B2 FPE was 62.5\%. A total of 138 SR kelts were detected at the BON dam face; 74 (53.6\%) passed through the spillway and 64 (46.4\%) passed through a powerhouse (23.9\% at B1 and $22.5 \%$ at B2; Table 4.2 ). After combining and regrouping SR and LCR kelts, 163 kelts were detected by the BON dam-face cabled array and nearly the same proportion of kelts passed via spillway and powerhouse routes (Table 4.2). Among 80 kelts detected at different powerhouse units, 41 (51.25\%) passed through B1 and 39 (48.75\%) passed through B2. At B1, 20 (49\%) passed through the B1 sluiceway and 21 (51\%) passed through turbines, while at B2, 29 (74.4\%) passed through 
the B2CC, 5 (12.8\%) passed through the JBS, and 5 (12.8\%) passed through B2 turbines (Table 4.3). The probability of turbine passage was higher for kelts passing via B1 (51\%) than for kelts passing via B2 $(12.8 \%)$.

Table 4.2. Passage proportions and survival rates with standard errors (SEs) for all kelts (combining SR and LCR kelts), SR kelts, and LCR kelts through Bonneville Dam. After dam passage survival at BON, major passage routes are listed based upon the ranked order of point estimates from highest to lowest passage survival although all estimates have overlapping $95 \%$ CIs.

\begin{tabular}{|c|c|c|c|c|c|c|c|c|c|}
\hline Route & $\begin{array}{c}\text { All } \\
\text { Kelts } \\
(\mathrm{N})\end{array}$ & $(\%)$ & Survival (SE) & $\begin{array}{c}\text { SR Kelts } \\
(\mathrm{N})\end{array}$ & $(\%)$ & Survival (SE) & $\begin{array}{c}\text { LCR } \\
\text { Kelts } \\
(\mathrm{N})\end{array}$ & $(\%)$ & Survival (SE) \\
\hline BON & 163 & & $0.8666(0.0270)$ & 138 & & $0.8999(0.0270)$ & 25 & & $0.6800(0.0933)$ \\
\hline Spillway & 83 & 50.92 & $0.9106(0.0329)$ & 74 & 53.62 & $0.9256(0.0322)$ & 9 & 36.00 & $0.7778(0.1386)$ \\
\hline $\mathrm{B} 1$ and $\mathrm{B} 2$ & 80 & 49.08 & $0.8226(0.0445)$ & 64 & 46.38 & $0.8706(0.0445)$ & 16 & 64.00 & $0.6250(0.1210)$ \\
\hline B1 & 41 & 25.15 & $0.7859(0.0653)$ & 33 & 23.91 & $0.7934(0.0719)$ & 8 & 32.00 & $0.7500(0.1531)$ \\
\hline B2 & 39 & 23.93 & $0.8626(0.0600)$ & 31 & 22.46 & $0.9531(0.0470)$ & 8 & 32.00 & $0.5000(0.1768)$ \\
\hline
\end{tabular}

Table 4.3. Passage percentages and survival rates with standard errors (SEs) for all kelts, SR kelts, and LCR kelts passing through Bonneville Dam routes and subroutes. Passage routes are listed based upon the ranked order of point estimate (highest to lowest) passage survival, even though all estimates had overlapping 95\% CIs.

\begin{tabular}{|c|c|c|c|c|c|c|c|c|c|}
\hline Sub-Route & $\begin{array}{c}\text { All } \\
\text { Kelts } \\
(\mathrm{N})\end{array}$ & $(\%)$ & Survival (SE) & $\begin{array}{c}\text { SR } \\
\text { Kelts } \\
(\mathrm{N})\end{array}$ & $(\%)$ & Survival (SE) & $\begin{array}{c}\text { LCR } \\
\text { Kelts } \\
(\mathrm{N})\end{array}$ & $(\%)$ & Survival (SE) \\
\hline $\mathrm{B} 2 \mathrm{CC}$ & 29 & 17.79 & $0.9458(0.0493)$ & 26 & 18.84 & $0.9423(0.0557)$ & 3 & 12.00 & $1.0000(0.0000)$ \\
\hline Spillway & 83 & 50.92 & $0.9106(0.0329)$ & 74 & 53.62 & $0.9256(0.0322)$ & 9 & 36.00 & $0.7778(0.1386)$ \\
\hline $\begin{array}{l}\text { Surface Flow } \\
\text { Outlets }\end{array}$ & 49 & 30.06 & $0.8869(0.0478)$ & 43 & 31.16 & $0.8702(0.0539)$ & 6 & 24.00 & $1.0000(0.0000)$ \\
\hline B1 Sluiceway & 20 & 12.27 & $0.8036(0.0900)$ & 17 & 12.32 & $0.7647(0.1029)$ & 3 & 12.00 & $1.0000(0.0000)$ \\
\hline B1 Turbine & 21 & 12.88 & $0.7692(0.0943)$ & 16 & 11.59 & $0.8250(0.1003)$ & 5 & 20.00 & 0.6000 \\
\hline All Turbines & 26 & 15.95 & $0.7385(0.0884)$ & 18 & 13.04 & $0.8426(0.0895)$ & 8 & 32.00 & $0.5000(0.1768)$ \\
\hline B2 JBS & 5 & 3.07 & 0.6000 & 3 & 2.17 & & 2 & 8.00 & \\
\hline B2 Turbine & 5 & 3.07 & 0.6000 & 2 & 1.45 & & 3 & 12.00 & \\
\hline
\end{tabular}

Sample sizes of LCR kelts passing through BON were too low to provide accurate survival estimates for BON or any major route through the dam. Dam passage survival for LCR kelts at BON was just 0.68 $(\mathrm{N}=25 ; \mathrm{SE}=0.0933)$. However, based on overlapping 95\% CIs, this point estimate did not differ significantly from a dam passage estimate for SR kelts $(\hat{S}=0.900)$ or all kelts $(0.867$; Table 4.2$)$. Small sample sizes and low precision for survival estimates for LCR kelts passing through the dam, spillway, B1, and B2 were responsible for overlapping 95\% CIs for LCR kelts and all kelts. In fact, the only point estimates (Table 4.2) that did not have overlapping 95\% CIs were for SR kelts passing through B2 ( $\hat{S}=$ $0.9531)$ and LCR kelts passing through B2 ( $\hat{S}=0.5000)$ (Figure 4.2). 


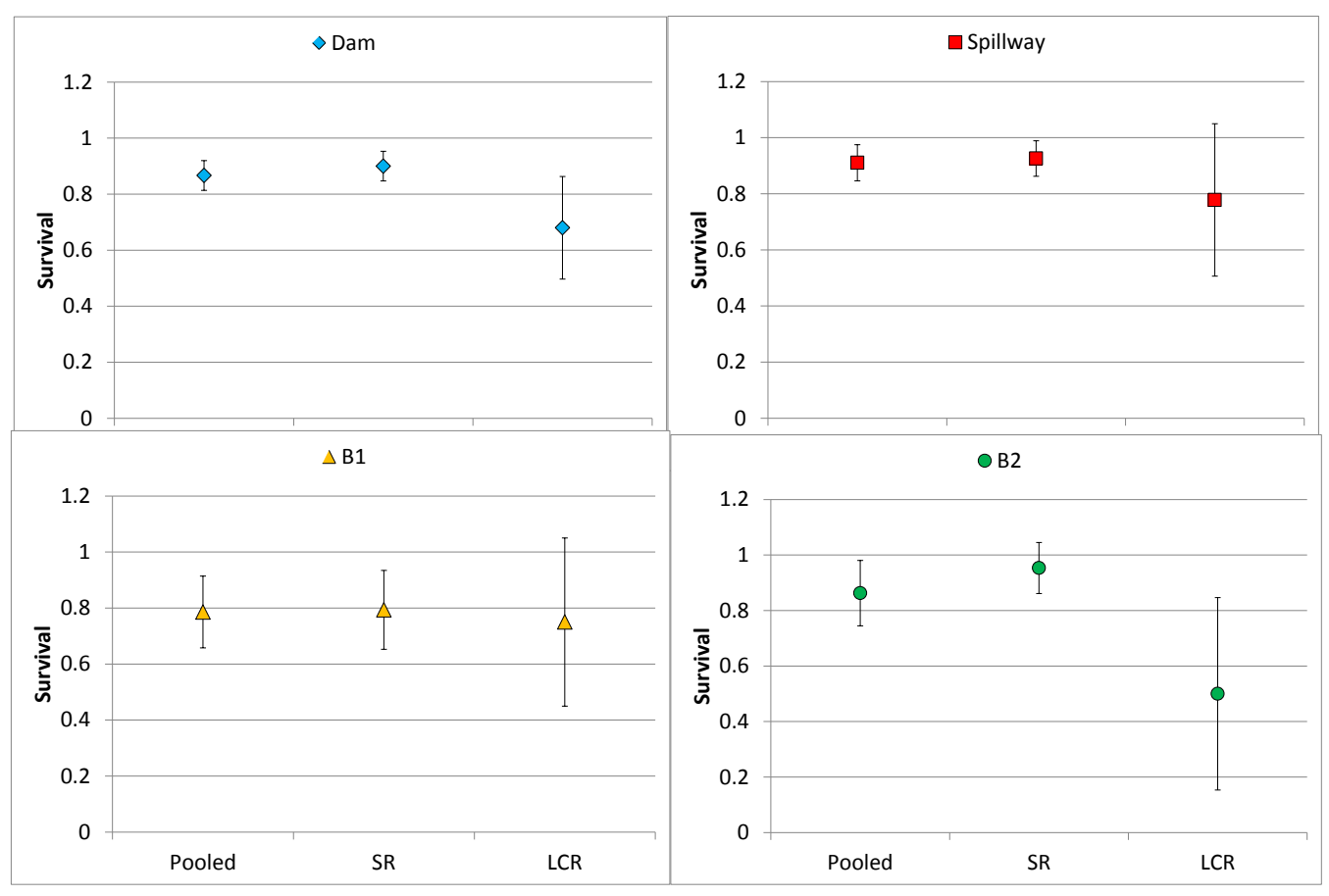

Figure 4.2. Survival estimates (with 95\% CI) for kelts through Bonneville Dam.

The combination of SR kelts and LCR kelts detected at BON (i.e., all kelts) resulted in relatively high dam survival rate $(0.8666 \%$ [SE $=0.027])$, which did not differ significantly from the rate for SR kelts $(0.8999$ [SE $=0.027])$. For all kelts and SR kelts, all point estimates had overlapping 95\% CIs, which suggests that estimates did not differ significantly, although there was a wide range among point estimates for the various routes (Table 4.3). Had sample sizes been higher and precision improved, survival rates for some of the routes may have differed. Based solely on point estimates (Table 4.3), the B2CC was the best route for passing kelts ( $\hat{S}=0.9458$ ), which was $14.2 \%$ higher than the point estimate for the B1 sluiceway ( $\hat{S}=0.8036$ ). The lowest survival rate for kelts passing through BON was 0.600 for passage through the B1 turbines (LCR kelts) and the B2 JBS (all kelts), but the sample size for each was only five kelts. The point estimate for B1 turbine passage survival was $0.769,3.4 \%$ lower than that recorded for the B1 sluiceway (Table 4.3).

\subsection{Travel Times and Rates}

Distribution statistics for reach travel times are summarized in Table 4.4, and statistics for travel rates are listed in Table 4.5. The tables are followed by sections describing median forebay residence and tailrace egress times. The distance between forebay and dam-face cabled arrays was approximately $2 \mathrm{~km}$ for TDA and BON. 
Table 4.4. Travel times (hours) for kelts passing through listed river reaches from release site to the most downstream array for the LCR in 2012 . Unlisted samples included two kelts released at Neal Creek, two at Asotin, and two at Crooked River because they were never detected and two released at Big Bear Weir because only one was detected in the LCR.

\begin{tabular}{|c|c|c|c|c|c|c|c|c|c|c|c|c|c|}
\hline $\begin{array}{c}\text { Release } \\
\text { Site }\end{array}$ & $\mathrm{N}$ & Reach & $\mathrm{km}$ & Mean & SE & $\mathrm{N}$ & Min & $10 \%$ & $25 \%$ & $50 \%$ & $75 \%$ & $90 \%$ & Max \\
\hline \multirow{6}{*}{$\begin{array}{l}\text { Fish } \\
\text { Creek }\end{array}$} & 52 & Release to TDA at rkm 309 & 635 & 290.84 & 8.48 & 4 & 271.00 & 271.00 & 277.23 & 291.59 & 304.45 & 309.17 & 309.17 \\
\hline & & TDA to BON Forebay (rkm 309-236) & 73 & 312.64 & 5.88 & 6 & 291.92 & 291.92 & 299.64 & 315.58 & 322.59 & 330.53 & 330.53 \\
\hline & & BON Forebay Residence Time (rkm 236-234) & 2 & 0.68 & & 1 & 0.68 & 0.68 & 0.68 & 0.68 & 0.68 & 0.68 & 0.68 \\
\hline & & BON Tailrace Egress Time (rkm 234-233) & 1 & & & 0 & & & & & & & \\
\hline & & Tailrace to Vancouver, WA (rkm 233-156) & 77 & 18.30 & 5.10 & 2 & 13.20 & 13.20 & 13.20 & 18.30 & 23.40 & 23.40 & 23.40 \\
\hline & & Vancouver, WA to Kalama, WA (rkm 156-113) & 43 & 10.55 & 1.85 & 3 & 8.42 & 8.42 & 8.42 & 9.02 & 14.23 & 14.23 & 14.23 \\
\hline \multirow{6}{*}{$\begin{array}{l}\text { E. Fork } \\
\text { Potlatch }\end{array}$} & 9 & Release to TDA at rkm 309 & 526 & 407.70 & 34.82 & 2 & 372.88 & 372.88 & 372.88 & 407.70 & 442.52 & 442.52 & 442.52 \\
\hline & & TDA to BON Forebay (rkm 309-236) & 73 & 426.00 & 32.99 & 2 & 393.01 & 393.01 & 393.01 & 426.00 & 458.99 & 458.99 & 458.99 \\
\hline & & BON Forebay Residence Time (rkm 236-234) & 2 & 0.30 & 0.06 & 2 & 0.24 & 0.24 & 0.24 & 0.30 & 0.36 & 0.36 & 0.36 \\
\hline & & BON Tailrace Egress Time (rkm 234-233) & 1 & 0.39 & & 1 & 0.39 & 0.39 & 0.39 & 0.39 & 0.39 & 0.39 & 0.39 \\
\hline & & Tailrace to Vancouver, WA (rkm 233-156) & 77 & 16.23 & & 1 & 16.23 & 16.23 & 16.23 & 16.23 & 16.23 & 16.23 & 16.23 \\
\hline & & Vancouver, WA to Kalama, WA (rkm 156-113) & 43 & 8.01 & 1.02 & 2 & 6.99 & 6.99 & 6.99 & 8.01 & 9.02 & 9.02 & 9.02 \\
\hline \multirow{6}{*}{$\begin{array}{l}\text { Joseph } \\
\text { Creek }\end{array}$} & 37 & Release to TDA at rkm 309 & 491 & 333.05 & 27.49 & 12 & 212.19 & 242.48 & 256.10 & 322.67 & 393.65 & 481.43 & 495.24 \\
\hline & & TDA to BON Forebay (rkm 309-236) & 73 & 361.79 & 28.37 & 11 & 228.56 & 275.19 & 288.69 & 352.98 & 468.18 & 500.52 & 512.58 \\
\hline & & BON Forebay Residence Time (rkm 236-234) & 2 & 0.61 & 0.14 & 11 & 0.28 & 0.31 & 0.31 & 0.47 & 0.59 & 1.20 & 1.79 \\
\hline & & BON Tailrace Egress Time (rkm 234-233) & 1 & 0.51 & 0.09 & 6 & 0.35 & 0.35 & 0.41 & 0.42 & 0.52 & 0.92 & 0.92 \\
\hline & & Tailrace to Vancouver, WA (rkm 233-156) & 77 & 17.84 & 0.70 & 6 & 14.93 & 14.93 & 17.10 & 18.02 & 19.16 & 19.82 & 19.82 \\
\hline & & Vancouver, WA to Kalama, WA (rkm 156-113) & 43 & 7.70 & 0.23 & 9 & 6.71 & 6.71 & 6.99 & 7.88 & 8.09 & 8.62 & 8.62 \\
\hline \multirow{6}{*}{$\begin{array}{l}\text { Little } \\
\text { Bear } \\
\text { Weir }\end{array}$} & 37 & Release to TDA at rkm 309 & 486 & 295.57 & 18.26 & 22 & 194.63 & 222.20 & 237.34 & 265.65 & 354.33 & 407.99 & 537.93 \\
\hline & & TDA to BON Forebay (rkm 309-236) & 73 & 323.80 & 21.99 & 20 & 212.15 & 241.95 & 253.93 & 275.87 & 430.27 & 452.32 & 556.16 \\
\hline & & BON Forebay Residence Time (rkm 236-234) & 2 & 1.38 & 0.51 & 19 & 0.30 & 0.30 & 0.40 & 0.58 & 1.31 & 4.55 & 9.70 \\
\hline & & BON Tailrace Egress Time (rkm 234-233) & 1 & 0.40 & 0.05 & 16 & 0.22 & 0.26 & 0.28 & 0.32 & 0.51 & 0.69 & 0.87 \\
\hline & & Tailrace to Vancouver, WA (rkm 233-156) & 77 & 20.36 & 2.74 & 13 & 15.23 & 15.57 & 16.40 & 17.26 & 19.45 & 23.78 & 52.40 \\
\hline & & Vancouver, WA to Kalama, WA (rkm 156-113) & 43 & 8.72 & 0.70 & 13 & 6.60 & 6.82 & 7.06 & 7.44 & 9.22 & 12.81 & 13.59 \\
\hline
\end{tabular}


Table 4.4. (contd)

\begin{tabular}{|c|c|c|c|c|c|c|c|c|c|c|c|c|c|}
\hline $\begin{array}{c}\text { Release } \\
\text { Site }\end{array}$ & $\mathrm{N}$ & Reach & $\mathrm{km}$ & Mean & SE & $\mathrm{N}$ & Min & $10 \%$ & $25 \%$ & $50 \%$ & $75 \%$ & $90 \%$ & Max \\
\hline \multirow{6}{*}{$\begin{array}{l}\text { LGR } \\
\text { Bypass }\end{array}$} & 181 & Release to TDA at rkm 309 & 386 & 215.83 & 4.48 & 107 & 128.53 & 157.60 & 188.07 & 208.45 & 245.58 & 278.08 & 386.66 \\
\hline & & TDA to BON Forebay (rkm 309-236) & 73 & 234.54 & 4.80 & 101 & 144.55 & 171.15 & 208.08 & 226.03 & 259.32 & 297.94 & 408.71 \\
\hline & & BON Forebay Residence Time (rkm 236-234) & 2 & 6.09 & 3.38 & 78 & 0.23 & 0.32 & 0.39 & 0.53 & 1.86 & 4.77 & 255.47 \\
\hline & & BON Tailrace Egress Time (rkm 234-233) & 1 & 4.59 & 3.97 & 50 & 0.22 & 0.29 & 0.30 & 0.38 & 0.50 & 0.91 & 199.13 \\
\hline & & Tailrace to Vancouver, WA (rkm 233-156) & 77 & 18.20 & 0.56 & 56 & 13.44 & 14.66 & 15.98 & 16.95 & 18.83 & 21.98 & 35.42 \\
\hline & & Vancouver, WA to Kalama, WA (rkm 156-113) & 43 & 8.48 & 0.25 & 73 & 5.71 & 6.83 & 7.24 & 7.98 & 8.83 & 10.79 & 20.26 \\
\hline \multirow{6}{*}{$\begin{array}{l}\text { Bake } \\
\text { Oven } \\
\text { Creek }\end{array}$} & 7 & Release to TDA at rkm 309 & 102 & 128.57 & 50.89 & 5 & 56.96 & 56.96 & 69.19 & 72.77 & 115.66 & 328.25 & 328.25 \\
\hline & & TDA to BON Forebay (rkm 309-236) & 73 & 94.51 & 3.27 & 3 & 90.32 & 90.32 & 90.32 & 92.26 & 100.95 & 100.95 & 100.95 \\
\hline & & BON Forebay Residence Time (rkm 236-234) & 2 & 6.46 & 6.09 & 2 & 0.37 & 0.37 & 0.37 & 6.46 & 12.54 & 12.54 & 12.54 \\
\hline & & BON Tailrace Egress Time (rkm 234-233) & 1 & 0.46 & 0.04 & 2 & 0.42 & 0.42 & 0.42 & 0.46 & 0.50 & 0.50 & 0.50 \\
\hline & & Tailrace to Vancouver, WA (rkm 233-156) & 77 & 23.93 & 6.49 & 3 & 16.72 & 16.72 & 16.72 & 18.18 & 36.88 & 36.88 & 36.88 \\
\hline & & Vancouver, WA to Kalama, WA (rkm 156-113) & 43 & 18.96 & & 1 & 18.96 & 18.96 & 18.96 & 18.96 & 18.96 & 18.96 & 18.96 \\
\hline \multirow{6}{*}{$\begin{array}{l}\text { Buck } \\
\text { Hollow }\end{array}$} & 17 & Release to TDA at rkm 309 & 88 & 45.11 & 9.46 & 8 & 16.73 & 16.73 & 24.49 & 35.88 & 65.42 & 92.57 & 92.57 \\
\hline & & TDA to BON Forebay (rkm 309-236) & 73 & 77.49 & 11.43 & 7 & 44.58 & 44.58 & 53.66 & 64.51 & 108.64 & 121.65 & 121.65 \\
\hline & & BON Forebay Residence Time (rkm 236-234) & 2 & 0.79 & 0.19 & 7 & 0.35 & 0.35 & 0.40 & 0.69 & 1.46 & 1.53 & 1.53 \\
\hline & & BON Tailrace Egress Time (rkm 234-233) & 1 & 1.40 & 0.90 & 6 & 0.27 & 0.27 & 0.38 & 0.54 & 0.79 & 5.86 & 5.86 \\
\hline & & Tailrace to Vancouver, WA (rkm 233-156) & 77 & 26.82 & 3.24 & 4 & 21.11 & 21.11 & 22.90 & 25.04 & 30.74 & 36.11 & 36.11 \\
\hline & & Vancouver, WA to Kalama, WA (rkm 156-113) & 43 & 14.90 & 2.98 & 3 & 9.42 & 9.42 & 9.42 & 15.63 & 19.65 & 19.65 & 19.65 \\
\hline \multirow{5}{*}{$\begin{array}{l}15 \text { Mile } \\
\text { Creek }\end{array}$} & 14 & Downstream of TDA to BON FB (rkm 309-236) & 73 & 122.85 & 68.18 & 7 & 40.69 & 40.69 & 44.84 & 55.94 & 75.58 & 531.05 & 531.05 \\
\hline & & BON forebay to Dam Face (rkm 236-234) & 2 & 48.00 & 46.61 & 6 & 0.33 & 0.33 & 0.36 & 0.81 & 4.62 & 281.04 & 281.04 \\
\hline & & BON Dam Face to Tailrace (rkm 234-233) & 1 & 2.24 & 1.67 & 4 & 0.34 & 0.34 & 0.36 & 0.70 & 4.12 & 7.23 & 7.23 \\
\hline & & Tailrace to Vancouver, WA (rkm 233-156) & 77 & 24.38 & 2.22 & 4 & 19.24 & 19.24 & 20.68 & 24.95 & 28.08 & 28.37 & 28.37 \\
\hline & & Vancouver, WA to Kalama, WA (rkm 156-113) & 43 & 9.61 & 0.87 & 3 & 8.41 & 8.41 & 8.41 & 9.11 & 11.31 & 11.31 & 11.31 \\
\hline \multirow{5}{*}{$\begin{array}{l}\text { Hood } \\
\text { River }\end{array}$} & 18 & Downstream of TDA to BON FB (rkm 273-236) & 37 & 249.38 & 34.82 & 10 & 45.43 & 79.97 & 203.71 & 262.09 & 307.18 & 386.64 & 419.26 \\
\hline & & BON forebay to Dam Face (rkm 236-234) & 2 & 5.79 & 2.33 & 10 & 0.24 & 0.30 & 0.39 & 2.24 & 10.42 & 17.04 & 22.92 \\
\hline & & BON Dam Face to Tailrace (rkm 234-233) & 1 & 0.29 & 0.03 & 7 & 0.20 & 0.20 & 0.24 & 0.30 & 0.35 & 0.41 & 0.41 \\
\hline & & Tailrace to Vancouver, WA (rkm 233-156) & 77 & 24.47 & 2.29 & 6 & 15.68 & 15.68 & 21.74 & 25.17 & 28.66 & 30.40 & 30.40 \\
\hline & & Vancouver, WA to Kalama, WA (rkm 156-113) & 43 & 11.64 & 1.88 & 6 & 7.11 & 7.11 & 8.23 & 10.37 & 14.14 & 19.65 & 19.65 \\
\hline
\end{tabular}


Table 4.5. Rate of travel $(\mathrm{km} / \mathrm{h})$ for kelts passing through listed river reaches from release site to the most downstream array for the LCR in 2012.

\begin{tabular}{|c|c|c|c|c|c|c|c|c|c|c|c|c|c|}
\hline $\begin{array}{l}\text { Release } \\
\text { Site }\end{array}$ & Obs & Reach & $\mathrm{km}$ & $\mathrm{N}$ & Mean & SE & Min & $10 \%$ & $25 \%$ & $50 \%$ & $75 \%$ & $90 \%$ & Max \\
\hline \multirow{6}{*}{$\begin{array}{c}\text { Fish } \\
\text { Creek }\end{array}$} & \multirow{6}{*}{52} & Release to TDA at rkm 309 & 635 & 4 & 2.19 & 0.06 & 2.05 & 2.05 & 2.09 & 2.18 & 2.29 & 2.34 & 2.34 \\
\hline & & TDA to BON Forebay (rkm 309-236) & 73 & 6 & 2.27 & 0.04 & 2.14 & 2.14 & 2.19 & 2.24 & 2.36 & 2.43 & 2.43 \\
\hline & & BON Forebay Residence Time (rkm 236-234) & 2 & 1 & 2.94 & & 2.94 & 2.94 & 2.94 & 2.94 & 2.94 & 2.94 & 2.94 \\
\hline & & BON Tailrace Egress Time (rkm 234-233) & 1 & 0 & & & & & & & & & \\
\hline & & Tailrace to Vancouver, WA (rkm 233-156) & 77 & 2 & 4.56 & 1.27 & 3.29 & 3.29 & 3.29 & 4.56 & 5.84 & 5.84 & 5.84 \\
\hline & & Vancouver, WA to Kalama, WA (rkm 156-113) & 43 & 3 & 4.30 & 0.65 & 3.02 & 3.02 & 3.02 & 4.77 & 5.11 & 5.11 & 5.11 \\
\hline \multirow{6}{*}{$\begin{array}{l}\text { E. Fork } \\
\text { Potlatch }\end{array}$} & \multirow{6}{*}{9} & Release to TDA at rkm 309 & 526 & 2 & 1.30 & 0.11 & 1.19 & 1.19 & 1.19 & 1.30 & 1.41 & 1.41 & 1.41 \\
\hline & & TDA to BON Forebay (rkm 309-236) & 73 & 2 & 1.41 & 0.11 & 1.31 & 1.31 & 1.31 & 1.41 & 1.52 & 1.52 & 1.52 \\
\hline & & BON Forebay Residence Time (rkm 236-234) & 2 & 2 & 6.95 & 1.41 & 5.54 & 5.54 & 5.54 & 6.95 & 8.36 & 8.36 & 8.36 \\
\hline & & BON Tailrace Egress Time (rkm 234-233) & 1 & 1 & 0.39 & & 0.39 & 0.39 & 0.39 & 0.39 & 0.39 & 0.39 & 0.39 \\
\hline & & Tailrace to Vancouver, WA (rkm 233-156) & 77 & 1 & 4.75 & & 4.75 & 4.75 & 4.75 & 4.75 & 4.75 & 4.75 & 4.75 \\
\hline & & Vancouver, WA to Kalama, WA (rkm 156-113) & 43 & 2 & 5.46 & 0.69 & 4.76 & 4.76 & 4.76 & 5.46 & 6.15 & 6.15 & 6.15 \\
\hline \multirow{6}{*}{$\begin{array}{l}\text { Joseph } \\
\text { Creek }\end{array}$} & \multirow{6}{*}{37} & Release to TDA at rkm 309 & 491 & 12 & 1.58 & 0.12 & 0.99 & 1.02 & 1.27 & 1.52 & 1.92 & 2.02 & 2.31 \\
\hline & & TDA to BON Forebay (rkm 309-236) & 73 & 11 & 1.66 & 0.13 & 1.10 & 1.13 & 1.20 & 1.60 & 1.95 & 2.05 & 2.47 \\
\hline & & BON Forebay Residence Time (rkm 236-234) & 2 & 11 & 4.48 & 0.60 & 1.12 & 1.67 & 3.40 & 4.24 & 6.38 & 6.49 & 7.13 \\
\hline & & BON Tailrace Egress Time (rkm 234-233) & 1 & 6 & 0.51 & 0.09 & 0.35 & 0.35 & 0.41 & 0.42 & 0.52 & 0.92 & 0.92 \\
\hline & & Tailrace to Vancouver, WA (rkm 233-156) & 77 & 6 & 4.35 & 0.18 & 3.89 & 3.89 & 4.02 & 4.27 & 4.50 & 5.16 & 5.16 \\
\hline & & Vancouver, WA to Kalama, WA (rkm 156-113) & 43 & 9 & 5.62 & 0.17 & 4.99 & 4.99 & 5.32 & 5.46 & 6.15 & 6.41 & 6.41 \\
\hline \multirow{6}{*}{$\begin{array}{l}\text { Little } \\
\text { Bear } \\
\text { Weir }\end{array}$} & \multirow{6}{*}{37} & Release to TDA at rkm 309 & 486 & 22 & 1.76 & 0.09 & 0.90 & 1.19 & 1.37 & 1.83 & 2.05 & 2.19 & 2.50 \\
\hline & & TDA to BON Forebay (rkm 309-236) & 73 & 20 & 1.86 & 0.11 & 1.01 & 1.24 & 1.30 & 2.03 & 2.20 & 2.31 & 2.63 \\
\hline & & BON Forebay Residence Time (rkm 236-234) & 2 & 19 & 3.37 & 0.46 & 0.21 & 0.44 & 1.53 & 3.44 & 4.95 & 6.62 & 6.62 \\
\hline & & BON Tailrace Egress Time (rkm 234-233) & 1 & 16 & 0.40 & 0.05 & 0.22 & 0.26 & 0.28 & 0.32 & 0.51 & 0.69 & 0.87 \\
\hline & & Tailrace to Vancouver, WA (rkm 233-156) & 77 & 13 & 4.19 & 0.26 & 1.47 & 3.24 & 3.96 & 4.46 & 4.69 & 4.94 & 5.06 \\
\hline & & Vancouver, WA to Kalama, WA (rkm 156-113) & 43 & 13 & 5.25 & 0.33 & 3.16 & 3.36 & 4.67 & 5.78 & 6.09 & 6.31 & 6.51 \\
\hline
\end{tabular}


Table 4.5. (contd)

\begin{tabular}{|c|c|c|c|c|c|c|c|c|c|c|c|c|c|}
\hline \multicolumn{14}{|l|}{ Release } \\
\hline Site & Obs & Reach & $\mathrm{km}$ & $\mathrm{N}$ & Mean & SE & $\operatorname{Min}$ & $10 \%$ & $25 \%$ & $50 \%$ & $75 \%$ & $90 \%$ & Max \\
\hline \multirow{6}{*}{$\begin{array}{c}\text { LGR } \\
\text { Bypass }\end{array}$} & \multirow{6}{*}{181} & Release to TDA at rkm 309 & 386 & 107 & 1.87 & 0.04 & 1.00 & 1.39 & 1.57 & 1.85 & 2.05 & 2.45 & 3.00 \\
\hline & & TDA to BON Forebay (rkm 309-236) & 73 & 101 & 2.03 & 0.04 & 1.12 & 1.54 & 1.77 & 2.03 & 2.21 & 2.68 & 3.18 \\
\hline & & BON Forebay Residence Time (rkm 236-234) & 2 & 78 & 3.40 & 0.27 & 0.01 & 0.42 & 1.08 & 3.75 & 5.19 & 6.29 & 8.56 \\
\hline & & BON Tailrace Egress Time (rkm 234-233) & 1 & 50 & 4.59 & 3.97 & 0.22 & 0.29 & 0.30 & 0.38 & 0.50 & 0.91 & 199.1 \\
\hline & & Tailrace to Vancouver, WA (rkm 233-156) & 77 & 55 & 4.39 & 0.10 & 2.17 & 3.50 & 4.05 & 4.54 & 4.83 & 5.25 & 5.73 \\
\hline & & Vancouver, WA to Kalama, WA (rkm 156-113) & 43 & 73 & 5.29 & 0.11 & 2.12 & 3.99 & 4.87 & 5.39 & 5.94 & 6.30 & 7.53 \\
\hline \multirow{6}{*}{$\begin{array}{c}\text { Bake } \\
\text { Oven } \\
\text { Creek }\end{array}$} & \multirow{6}{*}{7} & Release to TDA at rkm 309 & 102 & 5 & 1.17 & 0.26 & 0.31 & 0.31 & 0.88 & 1.40 & 1.47 & 1.79 & 1.79 \\
\hline & & TDA to BON Forebay (rkm 309-236) & 73 & 3 & 1.86 & 0.06 & 1.73 & 1.73 & 1.73 & 1.90 & 1.94 & 1.94 & 1.94 \\
\hline & & BON Forebay Residence Time (rkm 236-234) & 2 & 2 & 2.79 & 2.63 & 0.16 & 0.16 & 0.16 & 2.79 & 5.41 & 5.41 & 5.41 \\
\hline & & BON Tailrace Egress Time (rkm 234-233) & 1 & 2 & 0.46 & 0.04 & 0.42 & 0.42 & 0.42 & 0.46 & 0.50 & 0.50 & 0.50 \\
\hline & & Tailrace to Vancouver, WA (rkm 233-156) & 77 & 3 & 3.64 & 0.78 & 2.09 & 2.09 & 2.09 & 4.24 & 4.60 & 4.60 & 4.60 \\
\hline & & Vancouver, WA to Kalama, WA (rkm 156-113) & 43 & 1 & 2.27 & & 2.27 & 2.27 & 2.27 & 2.27 & 2.27 & 2.27 & 2.27 \\
\hline \multirow{6}{*}{$\begin{array}{l}\text { Buck } \\
\text { Hollow }\end{array}$} & \multirow{6}{*}{17} & Release to TDA at rkm 309 & 88 & 8 & 2.65 & 0.53 & 0.95 & 0.95 & 1.36 & 2.47 & 3.66 & 5.26 & 5.26 \\
\hline & & TDA to BON Forebay (rkm 309-236) & 73 & 7 & 2.36 & 0.33 & 1.32 & 1.32 & 1.48 & 2.50 & 3.00 & 3.61 & 3.61 \\
\hline & & BON Forebay Residence Time (rkm 236-234) & 2 & 7 & 3.41 & 0.67 & 1.31 & 1.31 & 1.37 & 2.92 & 4.97 & 5.78 & 5.78 \\
\hline & & BON Tailrace Egress Time (rkm 234-233) & 1 & 6 & 1.40 & 0.90 & 0.27 & 0.27 & 0.38 & 0.54 & 0.79 & 5.86 & 5.86 \\
\hline & & Tailrace to Vancouver, WA (rkm 233-156) & 77 & 4 & 2.98 & 0.31 & 2.13 & 2.13 & 2.58 & 3.08 & 3.38 & 3.65 & 3.65 \\
\hline & & Vancouver, WA to Kalama, WA (rkm 156-113) & 43 & 3 & 3.17 & 0.72 & 2.19 & 2.19 & 2.19 & 2.75 & 4.57 & 4.57 & 4.57 \\
\hline \multirow{5}{*}{$\begin{array}{c}15 \\
\text { Mile } \\
\text { Creek }\end{array}$} & \multirow{5}{*}{14} & Downstream of TDA to BON FB (rkm 309-236) & 73 & 7 & 1.21 & 0.21 & 0.14 & 0.14 & 0.97 & 1.31 & 1.63 & 1.79 & 1.79 \\
\hline & & BON forebay to Dam Face (rkm 236-234) & 2 & 6 & 2.84 & 1.03 & 0.01 & 0.01 & 0.43 & 2.49 & 5.52 & 6.10 & 6.10 \\
\hline & & BON Dam Face to Tailrace (rkm 234-233) & 1 & 4 & 2.24 & 1.67 & 0.34 & 0.34 & 0.36 & 0.70 & 4.12 & 7.23 & 7.23 \\
\hline & & Tailrace to Vancouver, WA (rkm 233-156) & 77 & 4 & 3.24 & 0.31 & 2.71 & 2.71 & 2.74 & 3.13 & 3.74 & 4.00 & 4.00 \\
\hline & & Vancouver, WA to Kalama, WA (rkm 156-113) & 43 & 3 & 4.55 & 0.39 & 3.80 & 3.80 & 3.80 & 4.72 & 5.11 & 5.11 & 5.11 \\
\hline \multirow{5}{*}{$\begin{array}{l}\text { Hood } \\
\text { River }\end{array}$} & \multirow{5}{*}{18} & Downstream of TDA to BON FB (rkm 309-236) & 73 & 10 & 0.22 & 0.07 & 0.09 & 0.10 & 0.12 & 0.14 & 0.18 & 0.57 & 0.81 \\
\hline & & BON forebay to Dam Face (rkm 236-234) & 2 & 10 & 2.48 & 0.93 & 0.09 & 0.13 & 0.19 & 1.14 & 5.16 & 7.06 & 8.51 \\
\hline & & BON Dam Face to Tailrace (rkm 234-233) & 1 & 7 & 0.29 & 0.03 & 0.20 & 0.20 & 0.24 & 0.30 & 0.35 & 0.41 & 0.41 \\
\hline & & Tailrace to Vancouver, WA (rkm 233-156) & 77 & 6 & 3.31 & 0.36 & 2.53 & 2.53 & 2.69 & 3.11 & 3.54 & 4.91 & 4.91 \\
\hline & & Vancouver, WA to Kalama, WA (rkm 156-113) & 43 & 6 & 4.14 & 0.58 & 2.19 & 2.19 & 3.04 & 4.16 & 5.22 & 6.04 & 6.04 \\
\hline
\end{tabular}




\subsubsection{The Dalles Dam}

Forebay residence time, tailrace egress time, and travel time could not be estimated for the LCR kelts passing through TDA because no forebay and tailrace detection arrays were installed in 2012. Fourteen of the 24 LCR kelts released upstream of TDA and detected at TDA passed through the dam by May 6 , prior to the installation of the TDA forebay (CR311) and tailrace (CR307) arrays on June 14, and therefore were not detected on those arrays. Only two of the 14 kelts detected at TDA were detected at the CR325 array in Celilo, Oregon.

The median forebay residence time of SR kelts detected at TDA after installation of the forebay and tailrace arrays was $0.6 \mathrm{~h}$ and the median tailrace egress time was $0.17 \mathrm{~h}$.

\subsubsection{Bonneville Dam}

Autonomous array detections at the BON forebay (CR236) and BON tailrace (CR233) were used to determine the forebay residence time, tailrace egress time, and project passage time for LCR and SR kelts detected on the BON dam-face cabled array. For LCR kelts detected at BON, the median forebay residence time was $0.793 \mathrm{~h}$ and the median tailrace egress time was $0.3753 \mathrm{~h}$. For SR kelts detected at $\mathrm{BON}$, the median forebay residence time was $0.5431 \mathrm{~h}$ and the median tailrace egress time was $0.3742 \mathrm{~h}$. Pooled estimates for all kelts were as follows: median forebay residence time was $0.5847 \mathrm{~h}$; median tailrace egress time was 0.3753 .

Forebay residence times tended to be longer for kelts passing through B1 than for those passing through B2 (Table 4.6), but differences in B1 and B2 tailrace egress times were only obvious for mean estimates (Table 4.7). High standard errors associated with all of these estimates would have produced overlapping $95 \%$ confidence intervals, so we are not writing about statistically significant differences, although differences in the point estimates should be informative to managers trying to set powerhouse priority.

\subsection{Passage Efficiency}

There were no apparent differences in passage efficiency estimates among all kelts, SR kelts, or LCR kelts passing through TDA based upon the overlap of 95\% CIs (Figure 4.3). A significantly higher proportion of kelts passed through the spillway than passed through the sluiceway, although SLE relative to the powerhouse was high (0.429-0.500; Table 4.8).

For kelts passing through BON, there were no apparent differences in efficiency estimates among all kelts, SR kelts, or LCR kelts based upon the overlap of 95\% CIs (Figure 4.4; Table 4.9) although the point estimates for all kelts and SR kelts often were higher than those for LCR kelts (e.g., FPE, SPE, SFO passage efficiency, B1 FPE, B2 FPE, and B2CC passage efficiency). For all kelts and SR kelts, significantly higher proportions passed through the spillway than passed through SFOs, but both routes were major contributors to BON FPE, which was $84 \%$ for all kelts. Fish passage efficiency for B2 (B2 FPE) was greater than that of B1 (B1 FPE) for all kelts and SR kelts. The sample size for LCR kelts was too small to allow a comparison of FPE for the two powerhouses. 
Table 4.6. Comparison of distribution statistics for forebay residence times (FB Res) of all, SR, and LCR kelts passing through B1 and B2 in 2012. The difference between estimates (B1 - B2) is in the column after the B2 estimates.

\begin{tabular}{|c|c|c|c|c|c|c|c|c|c|}
\hline \multirow[b]{2}{*}{ Statistic } & \multicolumn{3}{|c|}{ All Kelts } & \multicolumn{3}{|c|}{ SR Kelts } & \multicolumn{3}{|c|}{ LCR Kelts } \\
\hline & $\begin{array}{c}\text { FB } \\
\text { Res } \\
\text { Time, } \\
\text { h (B1) }\end{array}$ & $\begin{array}{c}\text { FB } \\
\text { Res } \\
\text { Time, } \\
\text { h (B2) }\end{array}$ & $\begin{array}{l}\text { Diff } \\
\text { (B1- } \\
\text { B2) }\end{array}$ & $\begin{array}{c}\text { FB Res } \\
\text { Time, } \\
\text { h (B1) }\end{array}$ & $\begin{array}{c}\text { FB Res } \\
\text { Time, } \\
\text { h (B2) }\end{array}$ & $\begin{array}{l}\text { Diff } \\
\text { (B1- } \\
\text { B2) }\end{array}$ & $\begin{array}{l}\text { FB Res } \\
\text { Time, } \\
\text { h (B1) }\end{array}$ & $\begin{array}{c}\text { FB } \\
\text { Res } \\
\text { Time, } \\
\text { h (B2) }\end{array}$ & $\begin{array}{l}\text { Diff } \\
\text { (B1- } \\
\text { B2) }\end{array}$ \\
\hline Mean & 14.32 & 3.42 & 10.89 & 8.08 & 0.70 & 7.38 & 6.84 & 38.03 & -31.19 \\
\hline Std Error & 7.03 & 3.15 & 3.88 & 2.80 & 0.22 & 2.59 & 2.81 & 34.74 & -31.93 \\
\hline $\mathrm{N}$ & 37.00 & 33.00 & 4.00 & 27.00 & 14.00 & 13.00 & 8.00 & 8.00 & 0.00 \\
\hline Minimum & 0.48 & 0.18 & 0.30 & 0.48 & 0.23 & 0.25 & 0.73 & 0.24 & 0.49 \\
\hline 1st Pctl & 0.48 & 0.18 & 0.30 & 0.48 & 0.23 & 0.25 & 0.73 & 0.24 & 0.49 \\
\hline 10th Pctl & 0.55 & 0.19 & 0.36 & 0.54 & 0.30 & 0.24 & 0.73 & 0.24 & 0.49 \\
\hline Lower Quartile & 1.20 & 0.24 & 0.97 & 1.03 & 0.37 & 0.66 & 1.00 & 0.34 & 0.65 \\
\hline Median & 2.84 & 0.2714 & 2.57 & 2.84 & 0.46 & 2.38 & 3.04 & 1.98 & 1.06 \\
\hline Upper Quartile & 6.40 & 0.32 & 6.08 & 5.94 & 0.59 & 5.35 & 11.48 & 9.14 & 2.34 \\
\hline 90th Pctl & 28.75 & 0.37 & 28.38 & 28.75 & 1.07 & 27.68 & 22.92 & 281.04 & 258.12 \\
\hline 99th Pctl & 255.47 & 104.27 & 151.21 & 65.69 & 3.42 & 62.27 & 22.92 & 281.04 & 258.12 \\
\hline Maximum & 255.47 & 104.27 & 151.21 & 65.69 & 3.42 & 62.27 & 22.92 & 281.04 & 258.12 \\
\hline
\end{tabular}

Table 4.7. Comparison of distribution statistics for forebay residence times (FB Res) of all, SR, and LCR kelts passing through B1 and B2 in 2012. The difference between estimates (B1 - B2) is in the column after the B2 estimates.

\begin{tabular}{|c|c|c|c|c|c|c|c|c|c|}
\hline \multirow[b]{2}{*}{ Statistic } & \multicolumn{3}{|c|}{ All Kelts } & \multicolumn{3}{|c|}{ SR Kelts } & \multicolumn{3}{|c|}{ LCR Kelts } \\
\hline & $\begin{array}{c}\text { FB } \\
\text { Res } \\
\text { Time, } \\
\text { h (B1) }\end{array}$ & $\begin{array}{c}\text { FB } \\
\text { Res } \\
\text { Time, } \\
\text { h (B2) }\end{array}$ & $\begin{array}{l}\text { Diff } \\
\text { (B1- } \\
\text { B2) }\end{array}$ & $\begin{array}{c}\text { FB Res } \\
\text { Time, } \mathrm{h} \\
\text { (B1) }\end{array}$ & $\begin{array}{l}\text { FB Res } \\
\text { Time, } \\
\text { h (B2) }\end{array}$ & $\begin{array}{c}\text { Diff } \\
\text { (B1-B2) }\end{array}$ & $\begin{array}{c}\text { FB } \\
\text { Res } \\
\text { Time, } \\
\text { h (B1) }\end{array}$ & $\begin{array}{l}\text { FB Res } \\
\text { Time, } \\
\text { h (B2) }\end{array}$ & $\begin{array}{l}\text { Diff } \\
\text { (B1- } \\
\text { B2) }\end{array}$ \\
\hline Mean & 6.57 & 0.41 & 6.16 & 8.15 & 0.36 & 7.78 & 1.24 & 0.50 & 0.74 \\
\hline Std Error & 5.67 & 0.09 & 5.58 & 7.35 & 0.10 & 7.26 & 0.86 & 0.15 & 0.71 \\
\hline $\mathrm{N}$ & 35.00 & 10.00 & 25.00 & 27.00 & 8.00 & 19.00 & 8.00 & 3.00 & 5.00 \\
\hline Minimum & 0.20 & 0.22 & -0.02 & 0.23 & 0.22 & 0.01 & 0.20 & 0.30 & -0.10 \\
\hline 1st Pctl & 0.20 & 0.22 & -0.02 & 0.23 & 0.22 & 0.01 & 0.20 & 0.30 & -0.10 \\
\hline 10th Pctl & 0.25 & 0.22 & 0.03 & 0.29 & 0.22 & 0.07 & 0.20 & 0.30 & -0.10 \\
\hline Lower Quartile & 0.29 & 0.24 & 0.06 & 0.31 & 0.23 & 0.08 & 0.25 & 0.30 & -0.05 \\
\hline Median & 0.37 & 0.29 & 0.08 & 0.39 & 0.28 & 0.11 & 0.29 & 0.41 & -0.12 \\
\hline Upper Quartile & 0.65 & 0.41 & 0.24 & 0.65 & 0.31 & 0.34 & 0.72 & 0.79 & -0.07 \\
\hline 90th Pctl & 1.02 & 0.91 & 0.10 & 0.93 & 1.04 & -0.11 & 7.23 & 0.79 & 6.44 \\
\hline 99th Pctl & 199.13 & 1.04 & 198.09 & 199.13 & 1.04 & 198.09 & 7.23 & 0.79 & 6.44 \\
\hline Maximum & 199.13 & 1.04 & 198.09 & 199.13 & 1.04 & 198.09 & 7.23 & 0.79 & 6.44 \\
\hline
\end{tabular}



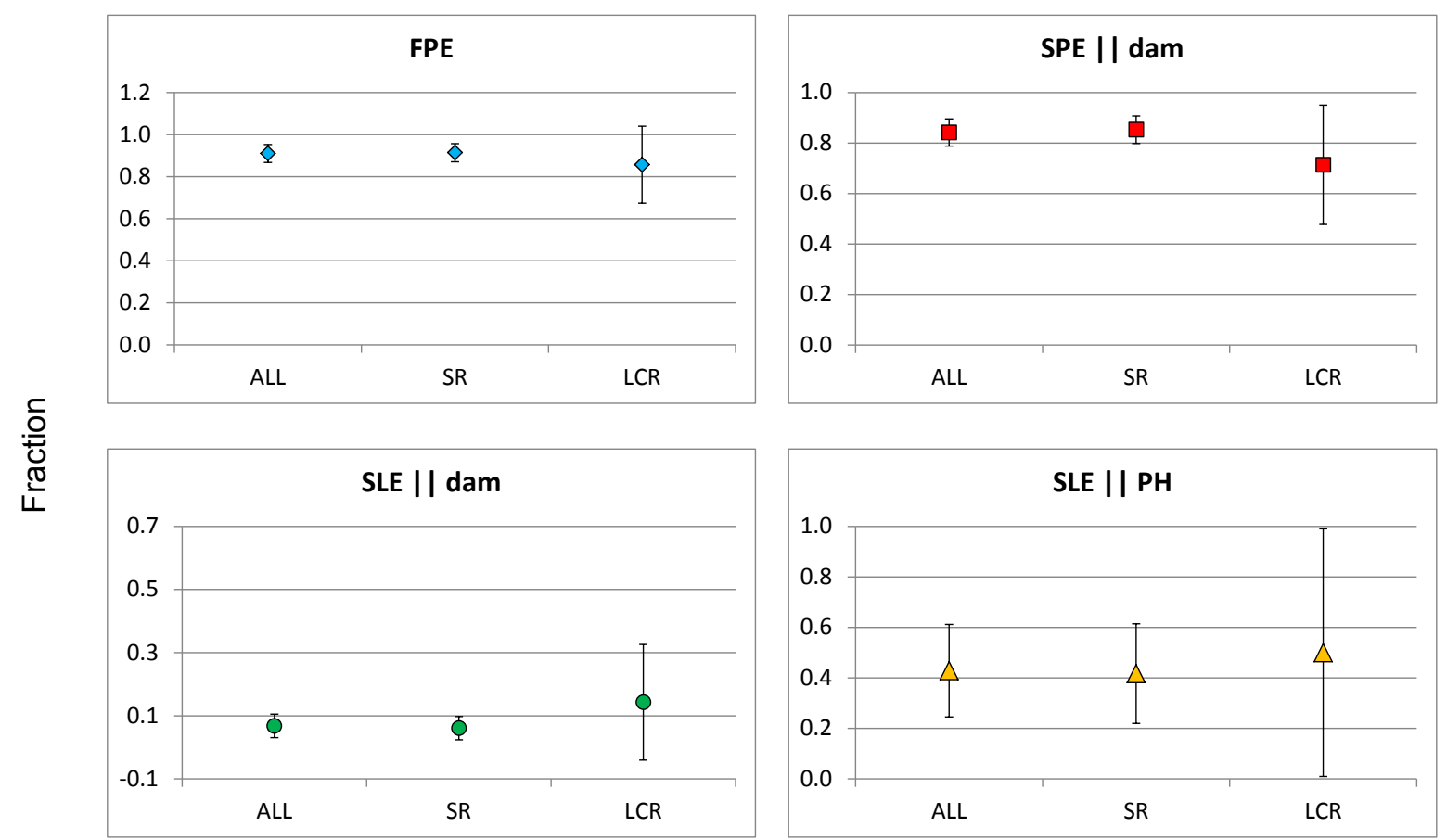

Figure 4.3. Passage efficiency estimates with 95\% CI for all kelts, SR kelts, and LCR kelts through The Dalles Dam.

Table 4.8. Fish passage efficiency (FPE), spillway passage efficiency (SPE), and sluiceway passage efficiency (SLE) for kelts passing through The Dalles Dam.

\begin{tabular}{lccccccccc}
\hline \multirow{2}{*}{$\begin{array}{c}\text { Performance } \\
\text { Metric }\end{array}$} & \multicolumn{3}{c}{ All Kelts } & \multicolumn{3}{c}{ SR Kelts } & \multicolumn{3}{c}{ LCR Kelts } \\
\cline { 2 - 11 } & Estimate & \multicolumn{1}{c}{ SE } & \multicolumn{1}{c}{$\mathrm{N}$} & Estimate & SE & \multicolumn{1}{c}{ N } & Estimate & SE & $\mathrm{N}$ \\
\hline FPE & 0.910 & 0.0216 & 177 & 0.914 & 0.0219 & 163 & 0.857 & 0.0935 & 14 \\
SPE || dam & 0.842 & 0.0274 & 177 & 0.853 & 0.0278 & 163 & 0.714 & 0.1207 & 14 \\
SLE || dam & 0.068 & 0.0189 & 177 & 0.061 & 0.0188 & 163 & 0.143 & 0.0935 & 14 \\
SLE || PH & 0.429 & 0.0935 & 28 & 0.417 & 0.1006 & 24 & 0.500 & 0.2500 & 4 \\
\hline
\end{tabular}



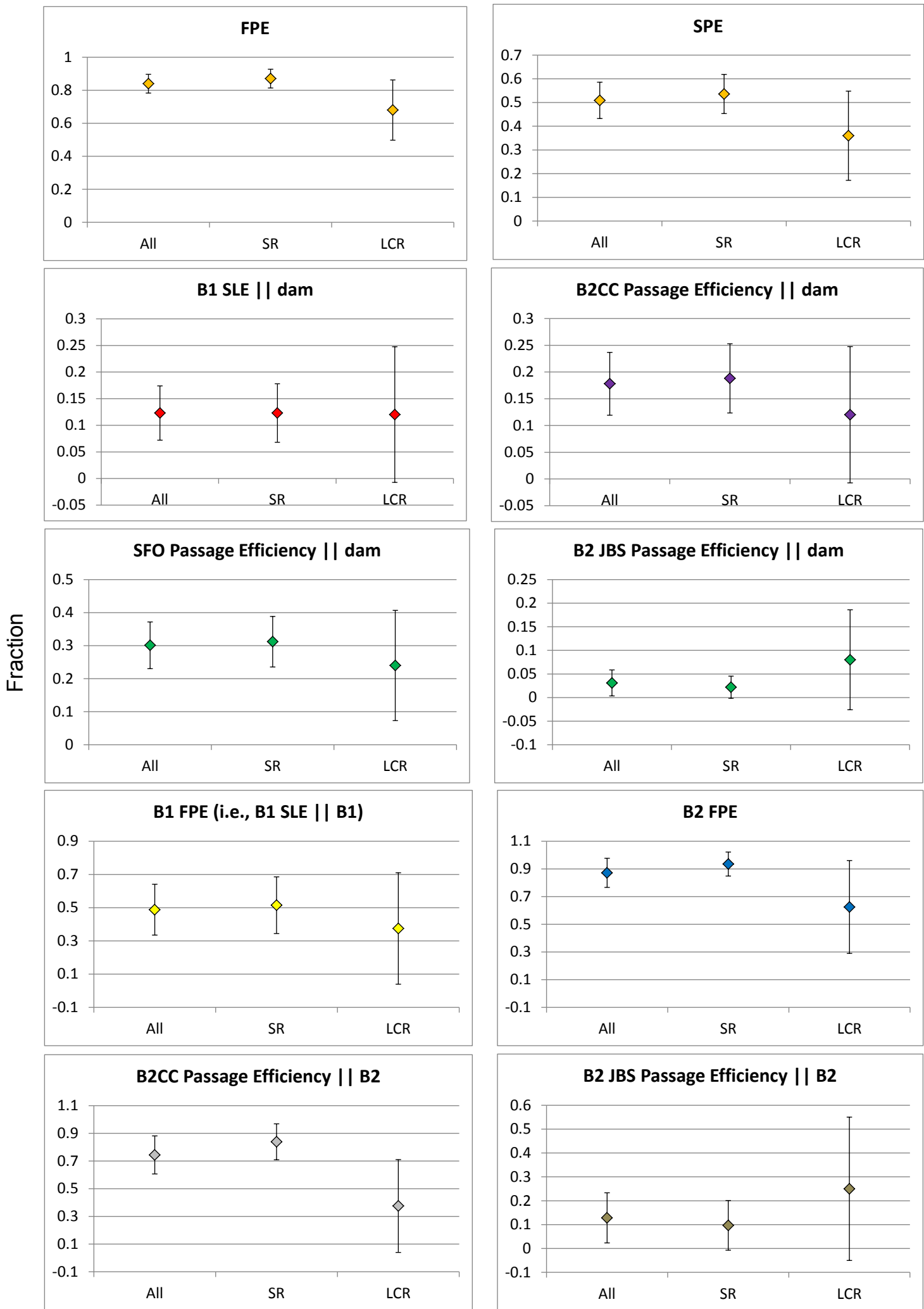

Figure 4.4. Passage efficiency estimates by route with $95 \%$ CI for all kelts, SR kelts, and LCR kelts through Bonneville Dam. 
The B2CC contributed more to B2 FPE than did the B2 JBS for LCR kelts as well, because very few kelts passed through B2 turbine units (Table 4.9). In general, the fish passage and sluiceway passage efficiencies for kelts detected at BON were greater at B2 than B1 (Table 4.9). The SPE for BON kelts was much lower than the SPE for TDA.

Table 4.9. Passage efficiency estimates by route for kelts passing through Bonneville Dam.

\begin{tabular}{lcccccccccc}
\hline & \multicolumn{3}{c}{ All Kelts } & \multicolumn{3}{c}{ SR Kelts } & \multicolumn{3}{c}{ LCR Kelts } \\
\cline { 2 - 10 } \multicolumn{1}{c}{ Performance Metric } & Estimate & SE & N & Estimate & SE & N & Estimate & SE & N \\
\hline FPE & 0.8400 & 0.0290 & 163 & 0.8700 & 0.0290 & 138 & 0.6800 & 0.0930 & 25 \\
SPE & 0.5090 & 0.0390 & 163 & 0.5360 & 0.0420 & 138 & 0.3600 & 0.0960 & 25 \\
B1 SLE || dam & 0.1230 & 0.0260 & 163 & 0.1230 & 0.0280 & 138 & 0.1200 & 0.0650 & 25 \\
B2CC Passage Efficiency || dam & 0.1780 & 0.0300 & 163 & 0.1880 & 0.0330 & 138 & 0.1200 & 0.0650 & 25 \\
SFO Passage Efficiency || dam & 0.3010 & 0.0360 & 163 & 0.3120 & 0.0390 & 138 & 0.2400 & 0.0850 & 25 \\
B2 JBS Passage Efficiency || dam & 0.0310 & 0.0140 & 163 & 0.0220 & 0.0120 & 138 & 0.0800 & 0.0540 & 25 \\
B1 FPE (i.e., B1 SLE || B1) & 0.4880 & 0.0781 & 41 & 0.5150 & 0.0870 & 33 & 0.3750 & 0.1712 & 8 \\
B2 FPE (i.e., B2 SLE || B2) & 0.8718 & 0.0535 & 39 & 0.9355 & 0.0441 & 31 & 0.6250 & 0.1712 & 8 \\
B2CC Passage Efficiency || B2 & 0.7440 & 0.0700 & 39 & 0.8390 & 0.0660 & 31 & 0.3750 & 0.1710 & 8 \\
B2 JBS Passage Efficiency || B2 & 0.1282 & 0.0535 & 39 & 0.0968 & 0.0531 & 31 & 0.2500 & 0.1531 & 8 \\
\hline
\end{tabular}

\subsection{Passage Effectiveness}

For all kelts passing through TDA, sluiceway passage effectiveness was significantly higher than spill passage effectiveness (Table 4.10), although for SR kelts and LCR kelts the effectiveness estimates for the sluiceway and spillway had overlapping 95\% CIs (Figure 4.5). Effectiveness estimates for the three kelt groups (all, SR, and LCR) did not differ based upon the overlap of $95 \%$ CIs. Relative to the powerhouse, the proportion of fish passing through the sluiceway was 18.7 to 22.5 times higher than the proportion of powerhouse water passing through the sluiceway (2.22\%) (Table 4.10). The average flow (in kcfs) through TDA from April 17 to July 15, 2012 via spillway, powerhouse, and sluiceway were 133.3, 197.9, and 4.4, respectively (Columbia River DART 2013).

Table 4.10. Passage effectiveness estimates for kelts passing through The Dalles Dam.

\begin{tabular}{lcccccccccc}
\hline & \multicolumn{3}{c}{ All Kelts } & \multicolumn{3}{c}{ SR Kelts } & \multicolumn{4}{c}{ LCR Kelts } \\
\cline { 2 - 10 } \multicolumn{1}{c}{ Performance Metric } & Estimate & SE & N & Estimate & SE & N & Estimate & SE & N \\
\hline Spill Passage Effectiveness || dam & 2.092 & 0.067 & 177 & 2.119 & 0.070 & 163 & 1.774 & 0.3006 & 14 \\
Sluiceway Passage Effectiveness $\|$ dam & 5.100 & 1.423 & 177 & 4.620 & 1.415 & 163 & 10.76 & 7.0413 & 14 \\
Sluiceway Passage Effectiveness $\|$ PH & 19.28 & 4.207 & 28 & 18.744 & 4.527 & 24 & 22.493 & 11.247 & 4 \\
\hline
\end{tabular}




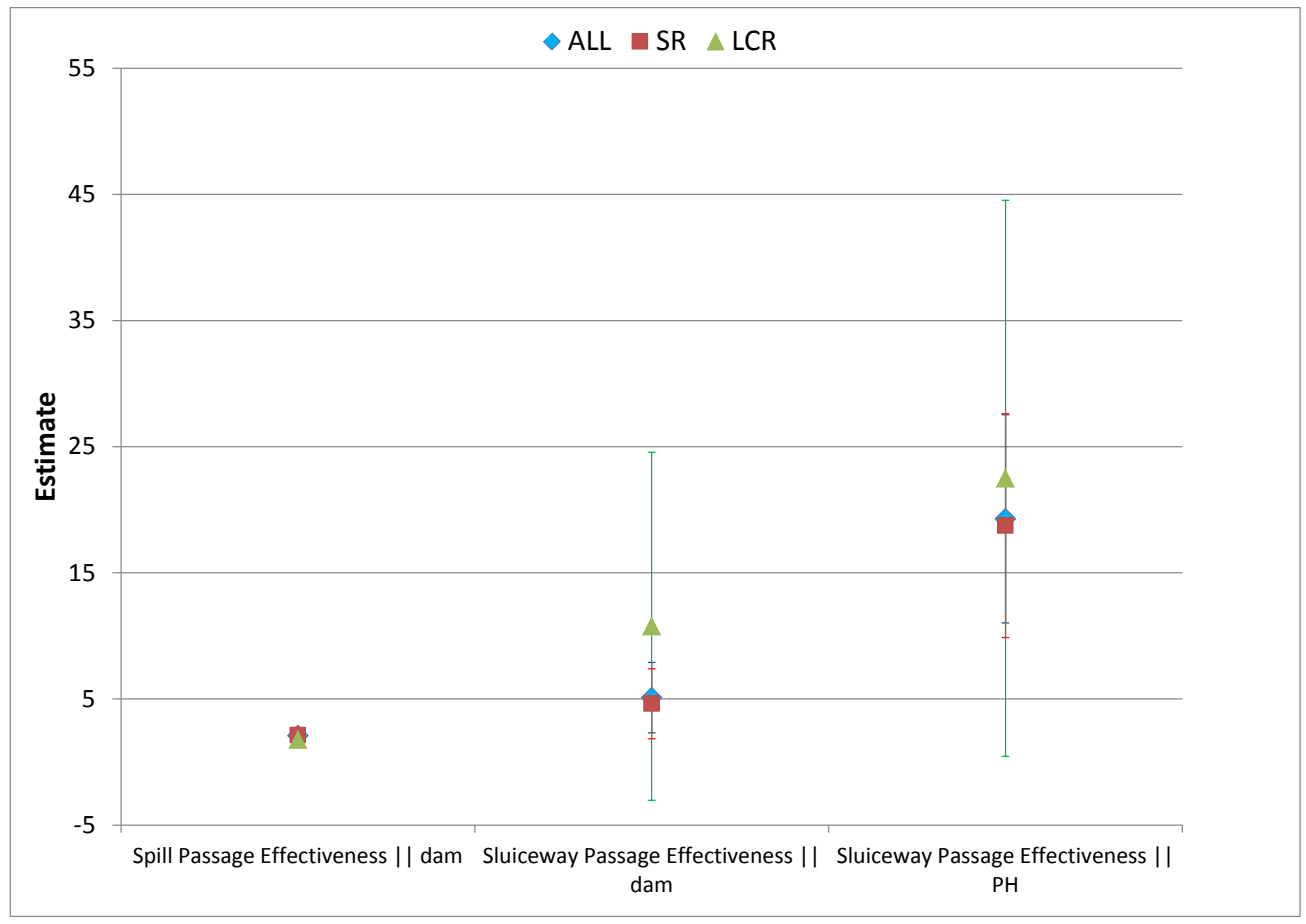

Figure 4.5. Passage effectiveness estimates with $95 \%$ CI for all kelts, SR kelts, and LCR kelts through Bonneville Dam.

For all kelts passing through BON, the sluiceways were clearly more effective than the spillway for passing kelts (Table 4.11; Figure 4.6). Effectiveness estimates did not differ among the three kelt groups based on overlapping $95 \%$ CIs. Relative to the entire dam, the effectiveness of the B1 sluiceway (40.60-41.67) was significantly higher than the effectiveness of the B2CC for passing kelts (8.53-13.39). Relative to the adjacent powerhouse, the B1 sluiceway passed $48.8 \%$ of all kelts that passed B1 in just $1.025 \%$ of water discharge through B1 (effectiveness $=47.6$ ). In contrast, the B2CC passed $74.36 \%$ of all kelts that passed B2 in just $4.54 \%$ of the water passing through B2 (effectiveness $=16.4$ ). The average flow (in kcfs) through BON from April 17 to July 15, 2012 via spillway, B1, B1 sluiceway, B2 and B2CC were 140.1, 100.5, 1.0, 108.1, and 4.9, respectively (Columbia River DART 2013).

Table 4.11. Passage effectiveness estimates for kelts passing through Bonneville Dam.

\begin{tabular}{lrrrrrrrrr}
\hline & \multicolumn{3}{c}{ All Kelts } & \multicolumn{3}{c}{ SR Kelts } & \multicolumn{3}{c}{ LCR Kelts } \\
\cline { 2 - 10 } \multicolumn{1}{c}{ Performance Metric } & Estimate & \multicolumn{1}{c}{ SE } & \multicolumn{1}{c}{ N } & Estimate & SE & N & Estimate & SE & N \\
\hline Spill Passage Effectiveness || dam & 1.268 & 0.0975 & 163 & 1.335 & 0.1057 & 138 & 0.896 & 0.2390 & 25 \\
B1 Sluiceway Passage Effectiveness $\|$ dam & 41.510 & 8.6936 & 163 & 41.670 & 9.4644 & 138 & 40.600 & 21.9866 & 25 \\
B2CC Passage Effectiveness || dam & 12.640 & 2.1281 & 163 & 13.385 & 2.3648 & 138 & 8.525 & 4.6173 & 25 \\
SFO Passage Effectiveness || dam & 17.650 & 2.1086 & 163 & 18.295 & 2.3148 & 138 & 14.091 & 5.0151 & 25 \\
B1 Sluiceway Passage Effectiveness $\|$ B1 & 47.571 & 7.6128 & 41 & 50.238 & 8.4842 & 33 & 36.570 & 16.6920 & 8 \\
B2CC Passage Effectiveness || B2 & 16.379 & 1.5401 & 39 & 18.474 & 1.4551 & 31 & 8.260 & 3.7702 & 8 \\
\hline
\end{tabular}



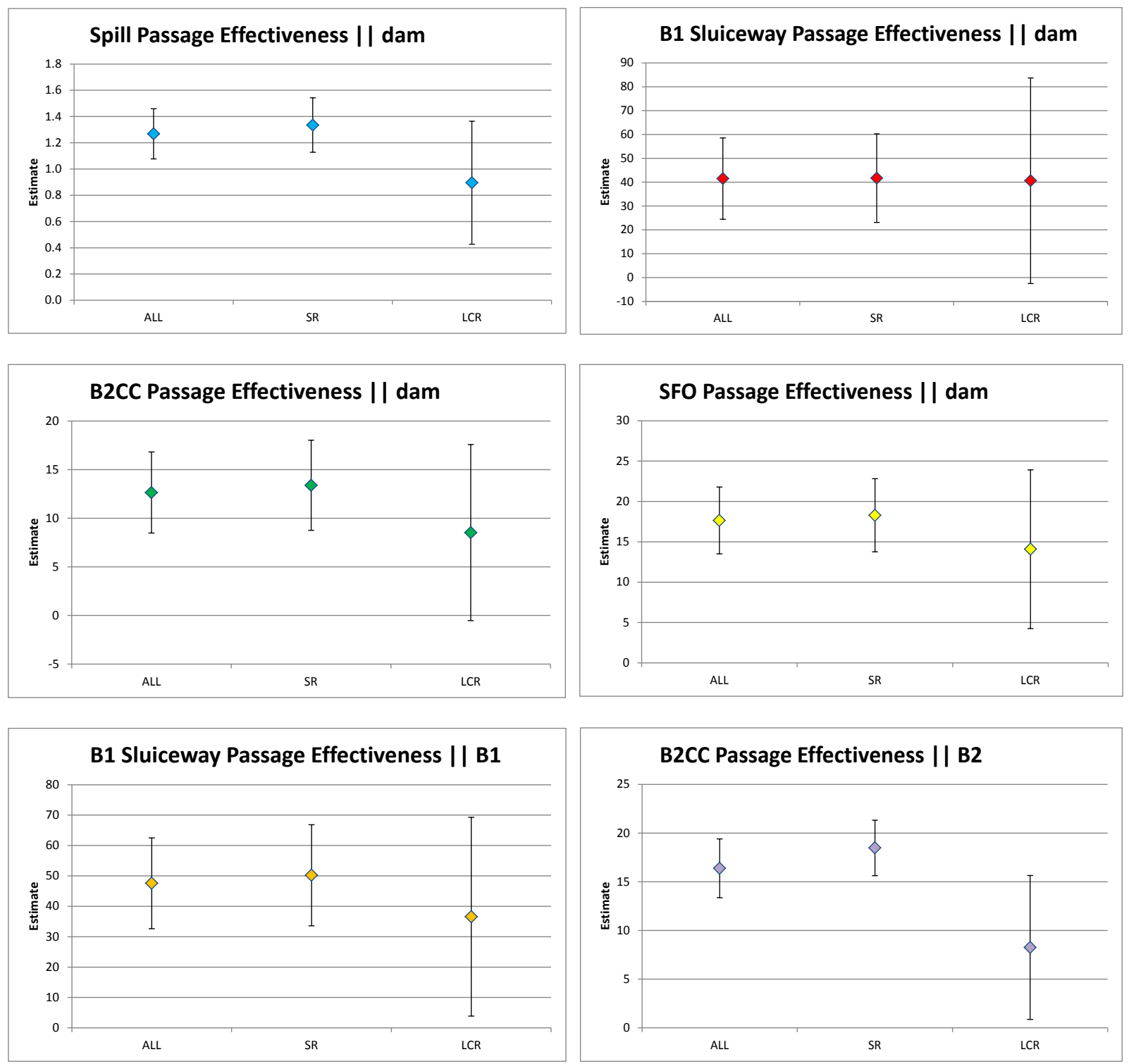

Figure 4.6. Passage effectiveness estimates (fish proportion/flow proportion) with $95 \%$ CI for kelts passing through Bonneville Dam.

\subsection{Iteroparity and Upstream Movement}

None of the kelts tagged in the LCR were PIT-detected at John Day Dam adult fish ladders in 2012 (i.e., all migrated downstream). It is recommended that researchers conducting subsequent kelt studies in the LCR record the percentage of surviving LCR and SR kelts migrating downstream in 2012 that are later PIT-detected in LCR fish ladders during upstream migration in 2013, 2014, and 2015, to provide an estimate of the iteroparity rate. 


\subsection{Kelt Condition and Release}

Kelt condition scores were based on 0 to 3 comments per fish. The final condition scores did not vary significantly with sex (males, females, undetermined), reproductive state (scores ranged from 2 to 3 ), or run type (clipped or unclipped) (all $\mathrm{p}>0.1741)$. However, kelt condition varied significantly with release location $\left(\chi^{2}(4)=18.8225, p=0.0009\right)$. More specifically, kelts tagged and released at the Hood River location were in better condition than Bakeoven Creek $<$ Buck Hollow Creek $<$ Fifteenmile Creek $<$ Neal Creek.

Notably, both Neal Creek kelts released were in opposing conditions, one in good condition with no maladies noted, and the other in poor condition with several maladies. These kelts were not detected on any array, which we attribute to the malady-free kelt not outmigrating, while the kelt that had maladies likely did not survive to the first array. Only 2 of 11 kelts noted to be in poor condition when released from other sites were detected, and only one was detected on the two most downriver arrays.

To better understand how fish condition influences kelt outmigration and detection, mean outmigration travel time (mm:ss $/ \mathrm{rkm}$ ) was estimated by release location and kelt condition. Kelts tagged at Bakeoven, Buck Hollow, and Fifteenmile creeks (66:58 $\pm 75: 00)$ outmigrated significantly faster than those tagged at Hood River $(318: 29 \pm 149: 25 ; \mathrm{F}(3,27)=12.28, \mathrm{p}<0.0001)$. Similarly, kelts in poor condition outmigrated significantly faster $(28: 54 \pm 11: 56 \mathrm{~mm}: \mathrm{ss} / \mathrm{rkm})$ than those in better condition $(280: 35 \pm 169: 39 \mathrm{~mm}: \mathrm{ss} / \mathrm{rkm}, \mathrm{F}(1,29)=10.40, \mathrm{p}=0.0031)$. The sex of the kelts was not found to significantly influence the mean travel time $(\mathrm{p}>0.6137)$. Run type was found to significantly influence the mean travel time $\left(\chi^{2}(1)=4.39, \mathrm{p}=0.0362\right)$; however, adipose clipped kelts were not released at each location, which may bias these findings.

The LCR kelt data suggest that release location and kelt condition can influence route of passage, but sample sizes were too low to test this hypothesis. 


\subsection{Discussion}

To overcome study limitations imposed by small sample sizes, kelts tagged and released in the Snake River were added to the LCR kelts to form virtual-release groups to bolster sample sizes and obtain reasonable inference from study results. Point estimates of dam passage survival for LCR kelts were lower than estimates for SR kelts at both TDA and BON, but given low precision and overlapping 95\% CIs, the LCR survival estimates likely did not differ significantly from estimates for SR kelts. A likely explanation for noticeably higher point estimates of dam passage survival for SR kelts is that the poorly conditioned fish died while outmigrating prior to reaching TDA and therefore were not included in the SR virtual-release group at TDA and BON. Consequently, a higher proportion of weak or injured LCR kelts survived to be regrouped into the virtual releases. In short, the weaker kelts were already filtered out of SR virtual releases, and only the stronger individuals persistently continued their downstream migration. A total of 13 LCR kelts (11 females, 1 male, and 1 unknown) were detected at the downstream most array (CR113) after traveling through TDA and BON. The statistical analysis tools used for determining survival rates and passage efficiency were developed for higher sample size runs and were very likely to be less efficient for small sample sizes. Thus, it was necessary to increase the sample size for a more realistic result, which was only possible by regrouping the SR kelts with LCR kelts detected at the TDA and BON dam-face cabled arrays. The start date of the project was delayed due to high flows observed in the tributaries during the fish collection and tagging period (April 12 to June 4), which contributed to the low numbers of obtainable LCR kelts. By the start of tagging, nearly $90 \%$ of the kelts in the tributaries had already migrated downstream after spawning. The continuous high flow observed during the fish collection period flooded weir traps and significantly reduced the efficiency of the remaining traps, resulting in an unexpectedly low sample size of 58 LCR kelts.

Based on pooled virtual-release groups of LCR and SR kelts $(\mathrm{N}=177)$, TDA kelt passage was highest at the spillway $(84.18 \%)$, and spillway passage survival ( $\hat{S}=91.3 \%$ ) was similar to that estimated for sluiceway passage, although only $6.8 \%$ of kelts passed through the latter route (Figure 5.1 ). Nevertheless, the sluiceway route was very important because it provided a safe alternative $(\hat{S}=93.08 \%)$ to passage through adjacent turbines $(\hat{S}=53.33 \%)$. A total of $42.86 \%$ of the kelts that passed through the TDA powerhouse passed via the sluiceway in just $2.22 \%$ of the powerhouse flow, yielding sluiceway passage effectiveness estimate of 19.3.

The 2012 study results for BON do not provide an unequivocal answer about which powerhouse to prioritize for power generation. High river discharge limited the operational control afforded to operators and did not emphasize the B1 powerhouse priority as much as in an average or low-water year. However, the high river flow did provide a good test bed for comparing metrics for the two powerhouses because both powerhouses were operated at available capacity. Between April 12 and July 15, 2012, B1 and B2 ran at approximately $94.2 \%$ and $81.4 \%$ of capacity, respectively. Most of the $12.1 \%$ difference was due to $\mathrm{B} 2$ turbines 11 and 14 being out of service $90 \%$ and $61.1 \%$ of the time, respectively.

While limited sample sizes resulted in high standard errors and few 95\% confidence intervals that did not overlap, differences in point estimates suggest that B2 should be the priority powerhouse for kelt passage, at least until more precise estimates demonstrate otherwise. This conclusion is based on the following observations from results. First, estimates of B2 FPE were higher than estimates for B1 FPE for all kelts (38.4\%), SR kelts (42.1\%), and LCR kelts (25.0\%). Second, estimates of B2CC passage efficiency relative to B2 were higher than estimates of B1 sluiceway efficiency for all kelts $(25.6 \%)$ and 
SR kelts (32.4\%) but not for LCR kelts. Third, the point estimate of B2 passage survival was 7.67\% higher than the estimate for B1 passage survival for all kelts, and for SR kelts it was $15.97 \%$ higher for B2 than it was for B1. Fourth, mean and median point estimates of forebay residence times usually were longer for kelts passing through B1 than they were for kelts passing through B2. For example, mean and median differences (B1 minus B2 forebay residence time) were $10.89 \mathrm{~h}$ and $2.57 \mathrm{~h}$ for all kelts and $7.38 \mathrm{~h}$ and $2.38 \mathrm{~h}$ for SR kelts. The difference in medians was $1.06 \mathrm{~h}$ for LCR kelts. While none of these differences was significant given the the sample sizes in this study, point estimate comparisions strongly suggest that B2 should be the priority powerhouse.

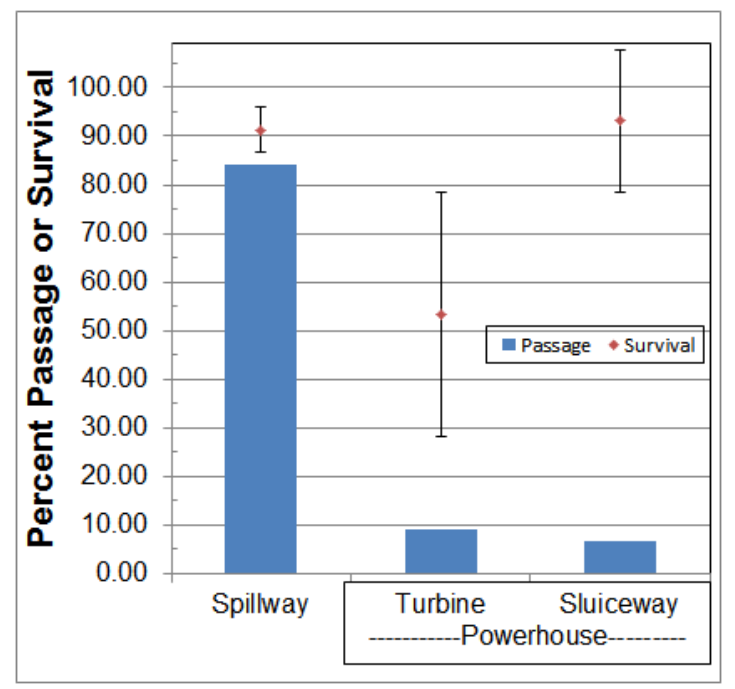

Figure 5.1. Kelt passage percentage and survival estimates for TDA routes. Vertical bars are $95 \%$ confidence intervals.

After pooling LCR and SR kelts, 163 kelts were detected at BON, 50.9\% passed through the spillway ( $\hat{S}=91.1 \%)$, and nearly equal proportions passed at B1 $(\hat{S}=78.6 \%)$ and B2 ( $\hat{S}=86.3 \%)$, although these route-specific survival rates do not differ significantly based on overlapping 95\% CIs (Figure 5.2). The B2 turbines and B2 JBS had the lowest point estimates of survival ( $\hat{S}=60 \%$ each), but given that only five kelts passed via each of these routes, the estimates were imprecise and not informative. The survival estimate for kelts passing via the B1 turbines $(\hat{S}=76.9 \%)$ was $16.9 \%$ higher than for the B2 turbines ( $\hat{S}=60.0 \%)$ and did not differ from the rate for the B1 sluiceway $(\hat{S}=80.4 \%)$. Unlike TDA, islands isolate powerhouse forebays from the spillway forebay at $\mathrm{BON}$, so that the proportion of kelts passing through B1, the spillway, and B2 likely is influenced more by bulk flow proportions to each forebay than by passage selection.

The B2CC provided a safer ( $\hat{S}=94.6 \%$ ) alternate route of passage for kelts passing through B2 compared to the B1 sluiceway at B1 (Figure 5.2). The B2CC passed $74.4 \%$ of kelts in $4.54 \%$ of B2 discharge, yielding an estimated effectiveness of 16.4, and the survival rate of those kelts was $34.6 \%$ higher than that of kelts passing through the B2 JBS or B2 turbines. At B1, kelts passed through the sluiceway and turbines in nearly equal proportions and with similar survival rates (Figure 5.1). Kelts passing through B1 turbines survived at a 16.9\% higher rate than kelts passing through B2 turbines, which may be due to the installation of minimum gap runner turbines at B1 and the slightly lower hydraulic head. 


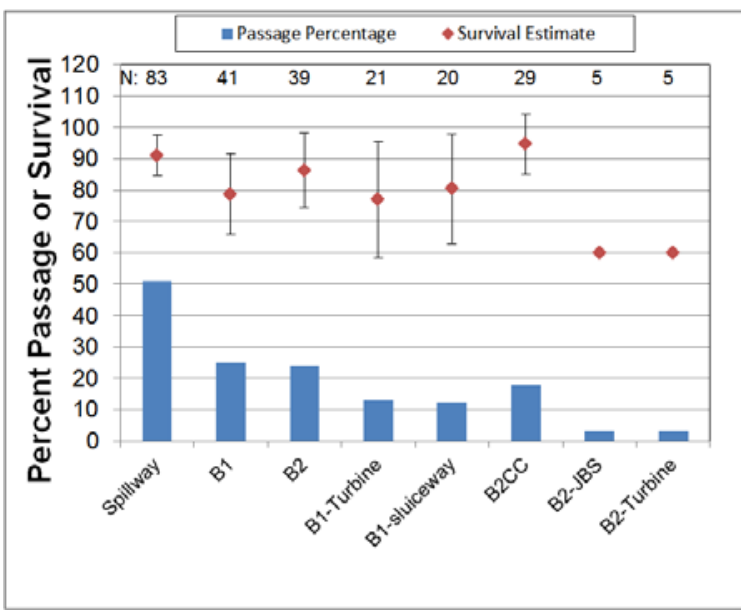

Figure 5.2. Kelt passage percentage and survival estimates for BON routes. Vertical bars are $95 \%$ confidence intervals, and they were not estimated for the B2 JBS or B2 turbines because only five kelts passed by each of these routes. 



\subsection{Conclusions}

Passage proportion and survival rates for routes at TDA and BON were informative only for pooled virtual releases of SR and LCR kelts, because only 58 LCR kelts could be trapped and tagged in the recurrently flooded tributaries. The $\mathrm{B} 2 \mathrm{CC}$ provides a safe alternative route of passage at $\mathrm{B} 2$ compared to the B1 sluiceway passage route at B1, although small sample sizes dictate caution in interpreting survival differences between the surface flow routes and the adjacent turbines. The 2012 high water year minimized differences in powerhouse generation and, along with limited route-specific sample sizes, prevented detection of statistically significant differences in most metrics between the two powerhouses at BON. However, results suggest that B2 should be the priority powerhouse for several reasons, at least until more robust statistics show otherwise. First, estimates of B2 FPE were higher than estimates for B1 FPE for all kelts (38.4\%), SR kelts (42.1\%), and LCR kelts (25.0\%). Second, estimates B2CC passage efficiency relative to B2 were higher than estimates of B1 sluiceway efficiency for all kelts (25.6\%) and SR kelts (32.4\%) but not for LCR kelts. Third, the point estimate of B2 passage survival was 7.67\% higher than the estimate for B1 passage survival for all kelts, and for SR kelts it was $15.97 \%$ higher for B2 than it was for B1. Fourth, mean and median point estimates of forebay residence times usually were longer for kelts passing through B1 than they were for kelts passing through B2. For example, mean and median differences (B1 minus B2 forebay residence time) were $10.89 \mathrm{~h}$ and $2.57 \mathrm{~h}$ for all kelts, $7.38 \mathrm{~h}$ and $2.38 \mathrm{~h}$ for SR kelts. The difference in medians was $1.06 \mathrm{~h}$ for LCR kelts.

Apparent differences in survival of SR and LCR kelts passing through TDA and BON may be the result of SR kelts having more time in-river than LCR kelts. Longer travel times could eliminate individuals in poor condition prior to the formation of the virtual releases at the LCR dams. We recommend repeating the study with the goal of tagging over 400 LCR individuals to produce robust passage proportion and survival estimates. 



\subsection{References}

Boggs CT, ML Keefer, and CA Peery. 2008. A Multi-year Summary of Steelhead Kelt Studies in the Columbia and Snake Rivers. Technical Report 2008-13, Idaho Cooperative Fish and Wildlife Research Unit, Moscow, Idaho.

Boggs CT, ML Keefer, CA Peery, TC Bjornn, and LC Stuehrenberg. 2004. "Fallback, reascension, and adjusted fishway escapement estimates for adult Chinook Salmon and Steelhead at Columbia and Snake River Dams." Transactions of the American Fisheries Society 133:932-949.

Booth RK, EB Bombadier, RS Mckinley, DA Scruton, and RF Gossney. 1997. "Swimming performance of post spawning (kelts) and juvenile (smolts) Atlantic salmon, Salmo salar." Canadian Manuscript Report of Fisheries and Aquatic Sciences No. 2406.

Busby PJ, TC Wainwright, GJ Bryant, LJ Lierheimer, RS Waples, FW Waknitz, and IV Lagomarsino. 1996. Status Review of West Coast Steelhead from Washington, Idaho, Oregon, and California. National Oceanic and Atmospheric Administration Technical Memorandum NMFSNWFSC-27, Seattle, Washington.

Colotelo AH, BW Jones, RA Harnish, GA McMichael, KD Ham, ZD Deng, GM Squeochs, RS Brown, MA Weiland, GR Ploskey, X Li, and T Fu. 2013. Steelhead Kelt Passage Distributions and FCRPS Survival for Fish Tagged Above and at Lower Granite Dam, 2012. PNNL-22101, prepared for the U.S. Army Corps of Engineers, Walla Walla District, by Pacific Northwest National Laboratory, Richland, Washington.

Columbia River DART, Columbia Basin Research, University of Washington. 2013. Adult Passage Daily Counts. Available at http://www.cbr.washington.edu/dart/query/adult_daily.

Ducharme LJA. 1969. "Atlantic Salmon Returning for their Fifth and Sixth Consecutive Spawning trips." Journal of the Fisheries Research Board of Canada 26:1661-1664.

Ford MJ (ed.). 2011. Status review update for Pacific salmon and steelhead listed under the Endangered Species Act: Pacific Northwest. U.S. Department of Commerce, National Oceanic and Atmospheric Administration Technical Memorandum NMFS-NWFSC-113, Seattle, Washington.

Lady JM, P Westhagen, and JR Skalski. 2010. Program ATLAS 1: Active Tag Life Adjusted Survival. Columbia Basin Research, School of Aquatic and Fishery Sciences, University of Washington, Seattle, Washington.

McClure MM, EE Holmes, BL Sanderson, and CE Jordan. 2003. "A Large-scale, Multispecies Status Assessment: Anadromous Salmonids in the Columbia River Basin.” Ecological Applications 13(4):964-989.

McMichael GA, MB Eppard, TJ Carlson, JA Carter, BD Ebberts, RS Brown, MA Weiland, GR Ploskey, RA Harnish, and ZD Deng. 2010. "The Juvenile Salmon Acoustic Telemetry System: A New Tool." Fisheries 35(1):9-22. 
Niemelä E, TS Makinen, K Moen, E Hassinen, J Erkinaro, M Lansman, and M Julkunen. 2000. "Age, Sex Ratio and Timing of the Catch of Kelts and Ascending Atlantic Salmon in the Subarctic River Teno." Journal of Fish Biology 56:974-985.

Scruton DA, CJ Pennell, CE Bourgeois, RF Goosney, TR Porter, and KD Clarke. 2007. “Assessment of a Retrofitted Downstream Fish Bypass System for Wild Atlantic Salmon(Salmo salar) Smolts and Kelts at a Hydroelectric Facility on the Exploits River, Newfoundland, Canada." Hydrobiologia 582:155-169.

Skalski JR, RL Townsend, A Seaburg, GR Ploskey, MA Weiland, JS Hughes, CM Woodley, Z Deng, and TJ Carlson. 2013a. Compliance Monitoring of Subyearling Chinook Salmon Survival and Passage at Bonneville Dam, Summer 2012. PNNL-22188, Pacific Northwest National Laboratory, Richland, Washington.

Skalski JR, RL Townsend, AG Seaburg, GR Ploskey, MA Weiland, JS Hughes, CM Woodley, Z Deng, TJ Carlson, and GE Johnson. 2013b. Compliance Monitoring of Subyearling Chinook Salmon Survival and Passage at The Dalles Dam, Summer 2012. PNNL-22195, compliance report submitted to the U.S. Army Corps of Engineers, Portland District, Portland, Oregon, by Pacific Northwest National Laboratory, Richland, Washington, and the University of Washington, Seattle, Washington.

Skalski JR, RL Townsend, AG Seaburg, MA Weiland, CM Woodley, JS Hughes, GR Ploskey, Z Deng, and TJ Carlson. 2013c. Compliance Monitoring of Yearling and Subyearling Chinook Salmon and Juvenile Steelhead Survival and Passage at John Day Dam, 2012. PNNL-22152, Pacific Northwest National Laboratory, Richland, Washington.

TAC (Technical Advisory Committee). 1997. Columbia River Fish Management Plan: 1996 AllSpecies Review. Technical Advisory Committee, U.S. v. Oregon, Report 222, U.S. Fish and Wildlife Service, Vancouver, Washington.

Waples RS. 1991. Definition of "Species" under the Endangered Species Act: Application to Pacific Salmon. U.S. Department of Commerce, National Oceanic and Atmospheric Administration Technical Memorandum NMFS-NWFSC-194, Seattle, Washington

Weiland MA, GR Ploskey, JS Hughes, Z Deng, T Fu, TJ Monter, GE Johnson, F Khan, MC Wilderding, AW Cushing, SA Zimmerman, RE Durham, DM Faber, RL Townsend, JR Skalski, J Kim, ES Fischer, and MM Meyer. 2009. Acoustic Telemetry Evaluation of Juvenile Salmonid Passage and Survival at John Day Dam with Emphasis on the Prototype Surface Flow Outlet. PNNL-18890, prepared for U.S. Army Corps of Engineers, Portland District, Oregon, by Pacific Northwest National Laboratory, Richland, Washington.

Weiland MA, CM Woodley, GR Ploskey, JS Hughes, MJ Hennen, J Kim, Z Deng, T Fu, JR Skalski, RL Townsend, KA Wagner, ES Fischer, JP Duncan, GE Johnson, GW Batten III, TJ Carlson, SM Carpenter, AW Cushing, T Elder, DJ Etherington, MJ Greiner, GE Johnson, F Khan, JJ Martinez, AL Miracle, TD Mitchell, K Prather, B Rayamajhi, IM Royer, AG Seaburg, and SA Zimmerman. 2013. Acoustic Telemetry Evaluation of Juvenile Salmonid Passage and Survival at John Day Dam, 2011. PNNL-22266, prepared for U.S. Army Corps of Engineers, Portland District, Oregon, by Pacific Northwest National Laboratory, Richland, Washington. 
Wertheimer RH. 2007. "Evaluation of a Surface Flow Bypass System for Steelhead Kelt Passage at Bonneville Dam, Washington.” North American Journal of Fisheries Management 27:21-29.

Wertheimer RH and AF Evans. 2005. "Downstream Passage of Steelhead Kelts through Hydroelectric Dams on the Lower Snake and Columbia Rivers." Transactions of the American Fisheries Society 134:853-865.

Winans GA, MM Paquin, DMV Doornik, BM Baker, P Thornton, D Rawding, A Marshall, P Moran, and S Kalinowski. 2004. "Genetic stock identification of Steelhead in the Columbia River Basin: An evaluation of different molecular markers." North American Journal of Fisheries Management $24: 672-685$. 

PNNL-22461, Revision 1

\section{Distribution}

No. of

Copies

OFFSITE

1 Derrek Faber

Oregon Department of Fish and Wildlife

3600 Crates Way Building 2 Suite A

The Dalles, OR 97058

1 Mike Langeslay

USACE Portland District

P.O. Box 2946

Portland, OR 97204

3 Robert Wertheimer

USACE Portland District

P.O. Box 2946

Portland, OR 97204
No. of

\section{Copies}

\section{ONSITE}

9 Pacific Northwest National Laboratory

$\begin{array}{lr}\text { AH Colotelo } & \mathrm{RCH} \\ \text { Z Deng } & \mathrm{RCH} \\ \text { T Fu } & \mathrm{RCH} \\ \text { J Kim } & \mathrm{RCH} \\ \text { GR Ploskey } & \mathrm{NBON}^{*} \\ \text { B Rayamajhi } & \mathrm{NBON}^{*} \\ \text { ML Johnson } & \mathrm{RCH} \\ \text { MA Weiland } & \mathrm{NBON}^{*} \\ \text { CM Woodley } & \mathrm{NBON}^{*}\end{array}$

*NBON copies sent to:

Gene Ploskey

390 Evergreen Drive

P.O. Box 241

North Bonneville, WA 98639 




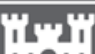

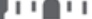

US Army Corps

of Engineers.

Prepared for the U.S. Army Corps of Engineers, Portland District,

under an Interagency Agreement with the U.S. Department of Energy

Contract DE-AC05-76RL01830

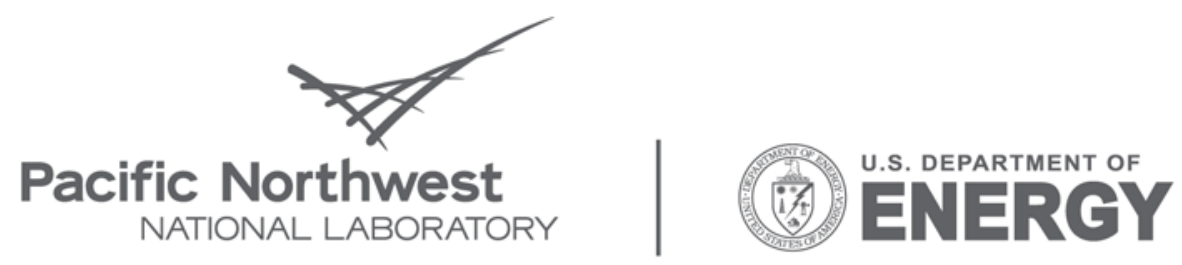

Proudly Operated by Battelle Since 1965

902 Battelle Boulevard

P.O. Box 999

Richland, WA 99352

1-888-375-PNNL (7665)

www.pnl.gov 